Universidad de Lima

Facultad de Comunicación

Carrera de Comunicación

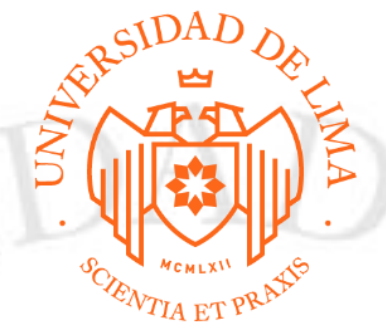

\title{
PLAN ESTRATÉGICO DE COMUNICACIÓN SELVA \& SALUD
}

Trabajo de Suficiencia Profesional para optar el Título Profesional de Licenciado en

Comunicación

\section{Andrea Lucía Farro Trigoso}

Código 20120479

Karina Mercedes Villavicencio Corzo

Código 20121394

\author{
Lima - Perú \\ Mayo de 2019
}




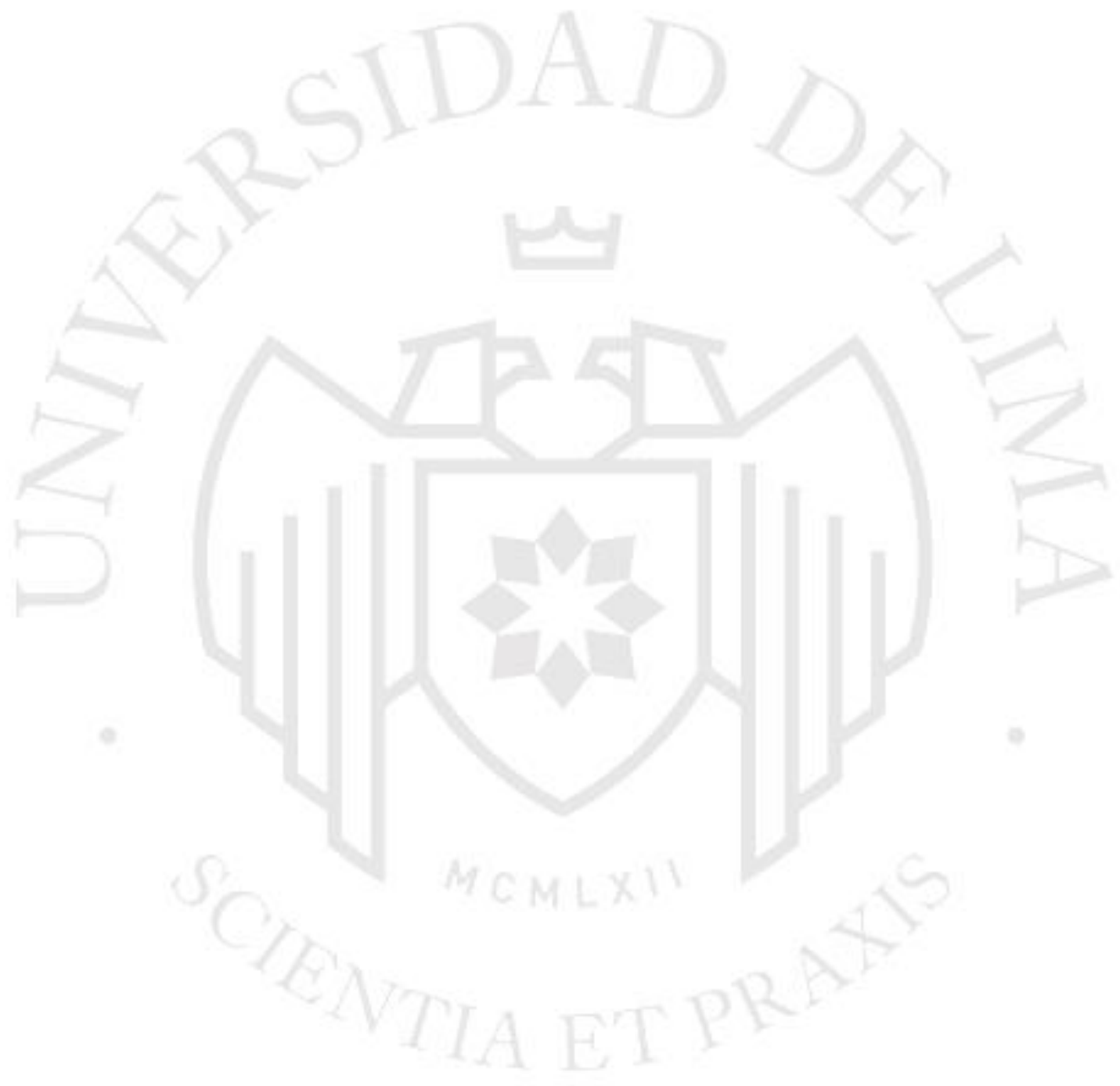




\section{PLAN ESTRATÉGICO DE COMUNICACIÓN SELVA \& SALUD}




\section{ÍNDICE}

\section{RESUMEN}

\section{INTRODUCCIÓN}

\section{CAPÍTULO I: LA EMPRESA}

1. Descripción de la empresa

2. Historia

3. Filosofía

3.1 Propósito

3.2 Misión

3.3 Visión

3.4 Valores

\subsection{Políticas}

4. Objetivos de la empresa

5. Organigrama

6. Problemas del negocio

\section{CAPÍTULO II: EL ENTORNO}

1. Macroentorno

1.1 Entorno político

1.2 Entorno económico

1.3 Entorno social

1.4 Entorno tecnológico

1.5 Industria del aceite de coco

a. Contexto internacional

b. Contexto nacional

1.6 Tendencias

$1.7 \mathrm{El}$ consumidor

2. Microentorno

2.1 La empresa

2.2 El producto y proceso

2.3 Público interno

2.4 Público externo

2.5 Competencia 


\section{CAPÍTULO III: DIAGNÓSTICO DE LA SITUACIÓN ACTUAL}

1. DAFO cruzado

2. FODA cruzado con los problemas del negocio

3. Canales de comunicación

4. Mapeo de stakeholders

5. Diagnóstico y problemas de comunicación

\section{CAPÍTULO IV: PLAN ESTRATÉGICO DE COMUNICACIÓN JULIO 2019 -}

\section{JULIO 2020}

1. Objetivos de comunicación

2. Público objetivo

3. Indicadores

4. Planes de comunicación

4.1 Plan de comunicación interna

4.2 Plan de comunicación externa

5. Matrices, cronograma y presupuesto

\section{CAPÍTULO V: ESTRATEGIA CREATIVA}

1. Elección de contenidos

2. Concepto creativo

\section{CAPÍTULO VI: IDENTIDAD CORPORATIVA}

1. Diagnóstico de identidad

2. Establecimiento de los estados corporativos

3. Configuración de la identidad visual corporativa

\section{CAPÍTULO VII: CANALES ESTRATÉGICOS DE COMUNICACIÓN}

1. Presenciales

2. Online

3. Offline 
8. CAPÍTULO VIII: PRESENTACIÓN DE LAS PIEZAS Y ELEMENTOS INTERNOS Y EXTERNOS

9. CAPÍTULO IX: PROYECCIÓN DEL PLAN ESTRATÉGICO DE COMUNICACIÓN AL 2023

RECOMENDACIONES

REFERENCIAS 


\section{RESUMEN}

Selva \& Salud es una empresa peruana que nace frente a la preocupación por la salud y el medioambiente, enfocando sus esfuerzos en la producción de un aceite de coco orgánico de calidad. Durante sus 20 años de trayectoria, ha mantenido la limpieza, frescura y naturalidad del producto gracias al proceso que utiliza para su obtención y la fertilidad de la selva peruana de donde proviene.

Se diseñará un plan estratégico de comunicación con el objetivo de transmitir el propósito y propuesta de valor de Selva \& Salud y potenciar el engagement con sus stakeholders, de modo que se logre la diferenciación y el crecimiento esperado de la empresa. Esto se realizará a partir de acciones de comunicación internas y externas que apoyaran al negocio en el logro de sus objetivos estratégicos.

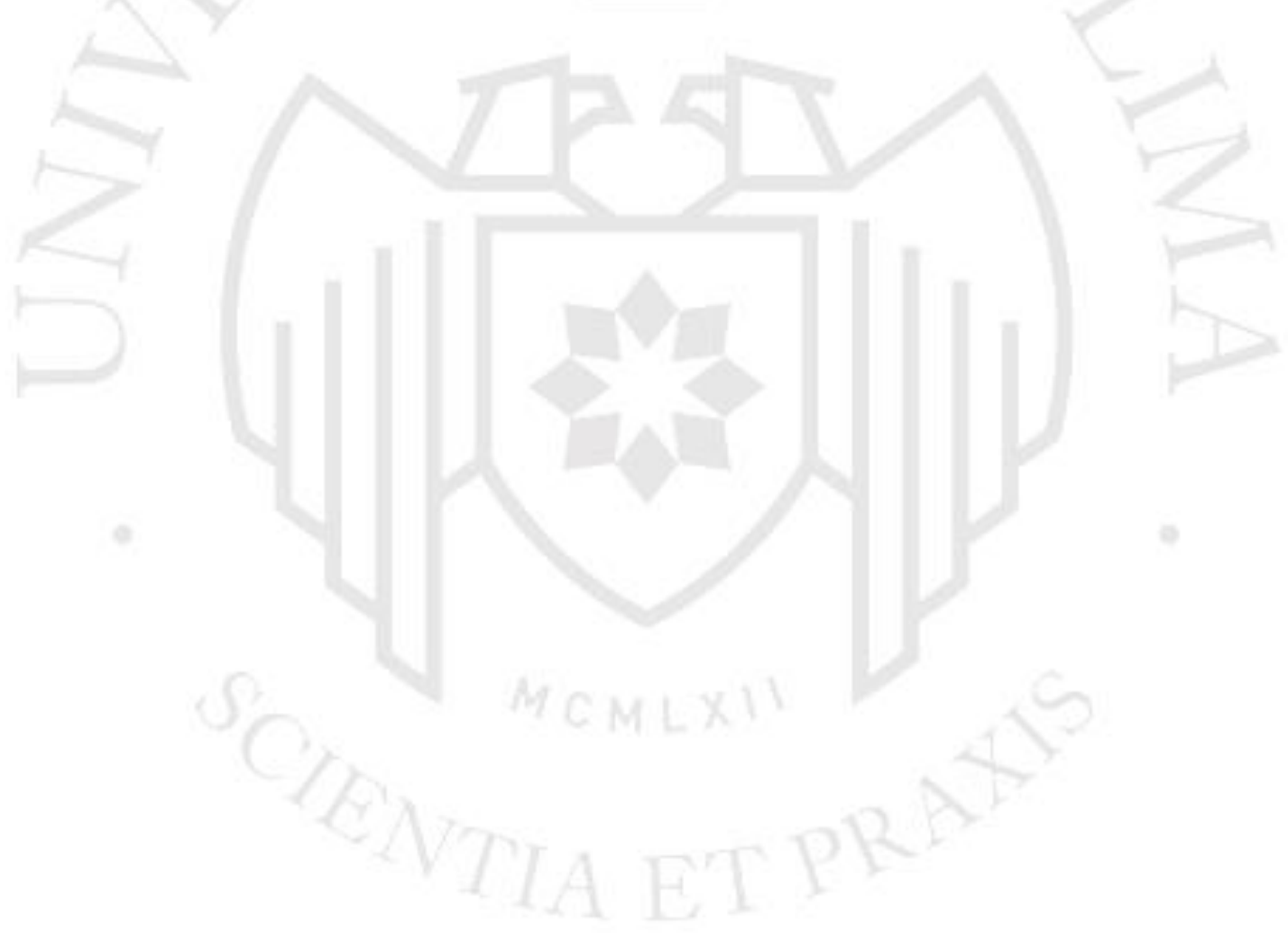




\section{INTRODUCCIÓN}

El siguiente trabajo tiene como objetivo realizar un Plan estratégico de Comunicación para la empresa Coco Peruano, la cual busca que su negocio de producción y venta de aceite de coco oránico crezca en los próximos cinco años a través de la incorporación de nuevos accionistas, el crecimiento de la fuerza laboral, y el apostar por la comunicación como estrategia para el logro de sus objetivos. Como punto de partida, el nombre de la empresa cambiará a Selva \& Salud como parte de la definición de su nueva identidad corporativa la cual será desarrollada en siguientes capítulos.

Primero se realizará una descripción y análisis de la identidad de la empresa. Luego, se efectuará un análisis del entorno del negocio y las principales tendencias que impactan en este. Con ambos análisis, se desarrollará el diagnóstico de la organización para identificar los desafíos que se pueden abordar desde la comunicación en un plan anual junio 2019 a julio 2019, así como una proyección a cinco años, a partir de la propuesta del plan estratégico de comunicación.

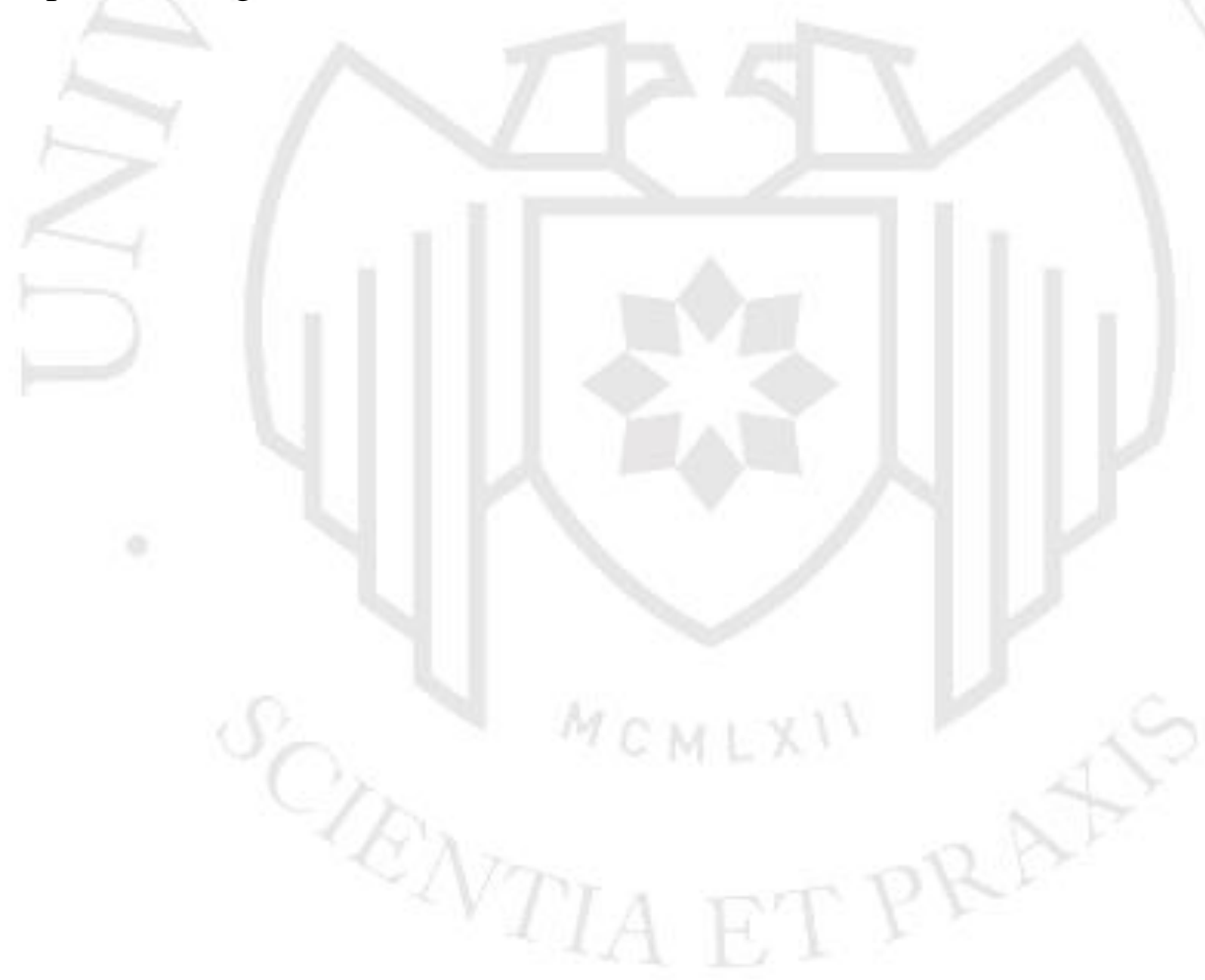




\section{CAPÍTULO I: LA EMPRESA}

\section{Descripción de la empresa}

Coco Peruano es una empresa peruana que nace frente a la preocupción por la salud y el medioambiente, enfocando sus esfuerzos en la producción de un aceite de coco orgánico de calidad. Durante sus 20 años de trayectoria, ha mantenido la limpieza, frescura y naturalidad del producto gracias al proceso que utiliza para su obtención y la fertilidad de la selva peruana de donde proviene.

Gracias a las comunidades sanmartinenses y a sus consumidores asiduos, continua su labor de hacer llegar a más peruanos un producto responsable con el medioambiente lleno del valor y riqueza que la selva peruana ofrece.

Además, mediante su elaboración y venta, continúa brindándole:

- A las comunidades del proyecto Coco Bosque en San Martín, una actividad sustentable que impacta a diversas generaciones de familias.

- A los consumidores, una opción de calidad en la que pueden confiar y con la que pueden mantener una experiencia grata de compra.

Coco Peruano, es una empresa que crea oportunidades de crecimiento en la selva peruana mientras apuesta por los beneficios del consumo natural responsable.

\section{Historia}

Coco Peruano es una empresa familiar fundada por tres hermanos en el 2000 dedicada a la producción del aceite de coco. La organización opera en dos localidades distintas: en San Martín se encuentra el equipo encargado de la producción y procesamiento liderado por dos de los socios, y en Lima labora el tercer socio liderando la administración y ventas a través de la participación en bioferias y desde el local que la empresa posee en Surquillo.

Coco Peruano cuenta con una trayectoria de 20 años. En los últimos años ha logrado aumentar su producción a través de una alianza estratégica con la ONG Amazónicos por la Amazonía (AMPA), y busca seguir creciendo como negocio en los siguientes cinco años.

En los próximos cinco años tiene prevista la incorporación de nuevos inversionistas quienes inyectarán capital a la empresa, el crecimiento del personal con la contratación de 100 empleados nuevos para la producción, administración y ventas, y la incorporación de tecnología en sus procesos. Todo esto con el objetivo de hacer crecer el negocio triplicando la producción del aceite de coco. 


\section{Filosofía}

\subsection{Propósito}

Somos Selva \& Salud, una empresa peruana familiar, ecoamigable y comprometida con fomentar el consumo responsable del aceite de coco y otros productos orgánicos nacionales en las familias peruanas, generando así un desarrollo sostenible en las comunidades productoras de la amazonía peruana.

\section{¿Cómo fomentamos un consumo responsable?}

- En nuestros colaboradores: Garantizando un proceso de producción orgánico que respete los más altos estándares de calidad y que busque siempre la mejora contínua y excelencia en beneficio y satisfacción de nuestro personal y clientes.

Escuchando y apoyándonos de nuestros clientes para continuar innovando y creando nuevos productos con el sello de calidad que nos representa.

- En nuestros clientes: Brindando a nuestros clientes información actualizada, accesible y de valor para que conozcan los beneficios de consumir productos más sostenibles y adopten un estilo de vida saluble y ecoamigable.

- En nuestra comunidad: Velando por el desarrollo de las familias que nos proveen con la base de nuestros productos y protegiendo el ecosistema para asegurar su sostenibilidad.

\subsection{Misión}

Ofrecer a nuestros clientes un aceite de coco de calidad superior, frescura y $100 \%$ natural, a través de una atención cercana y confiable que refleje nuestra tradición y compromiso con la comunidad y conservación del ecosistema.

\subsection{Visión}

Ser la principal opción para el consumo del aceite de coco y otros productos orgánicos que contribuya al crecimiento de una cultura ecoamigable en el Perú en los próximos cinco años.

\subsection{Valores}

En Selva \& Salud:

1. Somos responsables: Nuestra trayectoria respalda la transparencia y calidad que buscamos transmitir cada día desde nuestro rol; en la optimización de la cadena de valor de cada producto, así como en el contenido que ofrecemos a los grupos de interés con los que intactuamos para incentivar un consumo responsable.

2. Crecemos en equipo: Nuestros colaboradores son lo más importante; por ello, buscamos brindarles oportunidades para su desarrollo personal y profesional desde un ambiente de compañerismo, trabajo colaborativo y de corazón verde que les permita lograr sus metas y agregar valor a la empresa. 
3. Valoramos la diversidad: La riqueza de nuestro equipo, ubicado en la región de San Martín y Lima, nos permite unificar diversos talentos, apreciaciones, gama de conocimientos y experiencias en la generación de valor de nuestros productos y la atención personalizada que buscamos ofrecerle a nuestros clientes.

4. Estamos comprometidos con el medioambiente: Ante los diversos desafíos por los que atraviesa el planeta, nuestro propósito en la sensibilización ambiental es cada vez más importante. Creemos en el desarrollo sostenible y la protección del ecosistema, por lo que tratamos de reducir el impacto negativo de nuestras operaciones en el entorno. Además, el compromiso sincero que mantenemos con las comunidades productoras de la selva, nos lleva a apostar por su sostenibilidad y crecimiento.

5. Vivimos la creatividad e innovación: Siempre buscamos nuevas formas de hacer nuestro trabajo para lograr más y mejores resultados. Desde el rol de cada uno, fomentamos la generación de ideas creativas que desafíen los paradigmas y nos lleven a transformar nuestra realidad hacia un estilo de vida ecoamigable.

\subsection{Políticas}

Las políticas son las guias que articulan la visión de Selva \& Salud respecto a su día a día. Su objetivo es que las decisiones de todos los colaboradores estén acordes y representen el estilo de vida y filosofía que se pregona En ese sentido, las políticas son una herramienta valiosa para orientar la labor, facilitando la toma de decisiones y una mayor autononía y claridad.

- Incorporación: Al incorporarse a Selva \& Salud, cada colaborador debe llenar una ficha personal, abrir una cuenta corriente o de ahorros en el banco de su preferencia. De ser el caso, recibirá tarjetas corporativas, y se le asignará una cuenta de correo electrónico.

- Trato dentro de la empresa: En Selva \& Salud se promueve una cultura basada en la responsabilidad, un ambiente de camaradería, respeto mutuo, e integridad. Se aplica la política de puertas abiertas en las gerencias y jefaturas.

- Horario laboral: La jornada laboral en Selva \& Salud es de máximo 48 horas semanales. El horario de ingreso es a las 9 a. m. y la salida a partir de las 6:00 p. m.

- Ausencias: La inasistencia debe ser reportada a primera hora del día y justificada ante el jefe inmediato superior. Toda ausencia por enfermedad debe sustentarse con el certificado correspondiente.

- Vestimenta: La vestimenta en Selva \& Salud es casual. En el caso de las reuniones de trabajo externas, ya sea con clientes o proveedores, se deberá utilizar una vestimenta más formal.

- Vacaciones: Los colaboradores tienen derecho a 30 días calendario de vacaciones al año. Las fechas deben ser comunicadas con mínimo 15 días de anticipación al jefe inmediato superior. 
- Reuniones internas: Además de las reuniones por área, Selva \& Salud cuenta con reuniones a las que debe asistir todo el personal como el Desayuno "Buenos días, Selva \& Salud" que se realiza una vez al mes. El último jueves del mes se celebran los cumpleaños del mes.

\section{Objetivos de la empresa}

En los próximos cinco años, la empresa se ha planteado los siguientes objetivos:

- Triplicar la producción de aceite de coco.

- Utilizar la comunicación organizacional para construir la propuesta de valor de Coco Peruano con el objetivo de ser mas competitivos y tener una mejor relación con los grupos de interés.

- Lograr el crecimiento del negocio en las principales cuidades del país mediante la aplicación de la tecnología en los diferentes procesos de la cadena de valor del aceite de coco.

- Aumentar la fuerza laboral para potenciar el proceso de producción, administración y ventas de la organización.

\section{Organigrama}

Actualmente, la empresa cuenta con 53 colaboradores distribuidos según el siguiente organigrama:

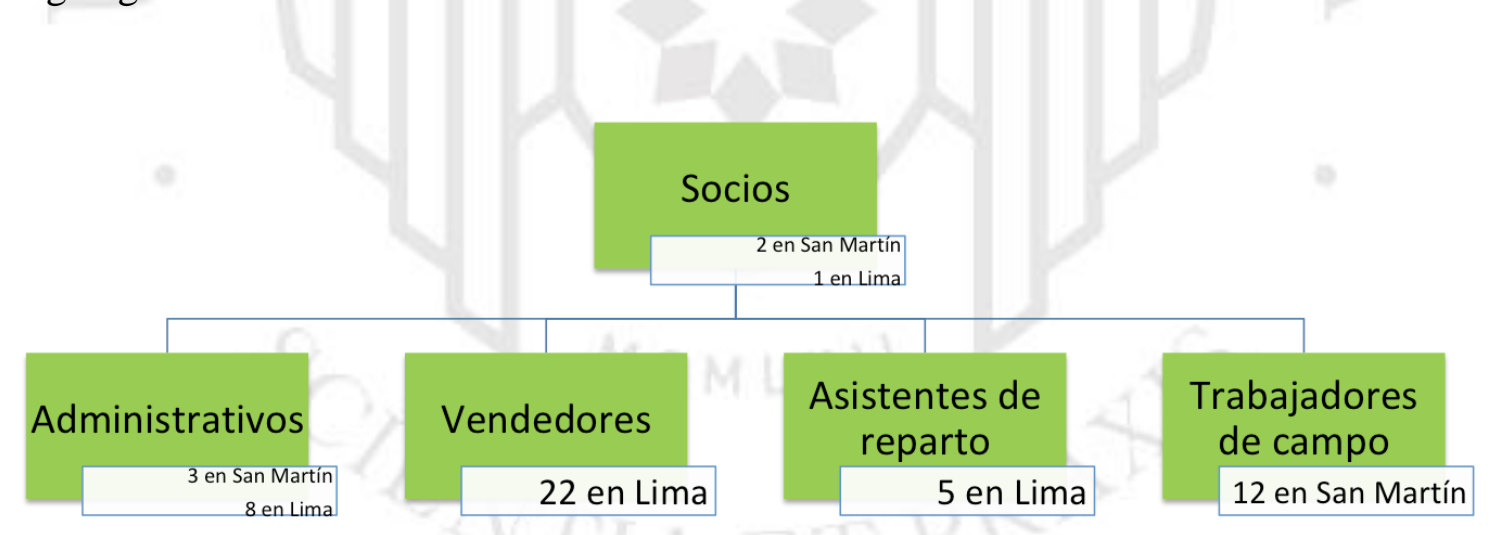

Para la planificación de este año, se propone la siguiente restructuración inicial con el objetivo de poder distribuir mejor las funciones y contar con responsables que puedan llevar a cabo el plan. Es importante reconocer que, frente a nuevos colaboradoresen la organizacion el organigrama mostrará ciertas modificaciones de crecimiento y movimiento: 


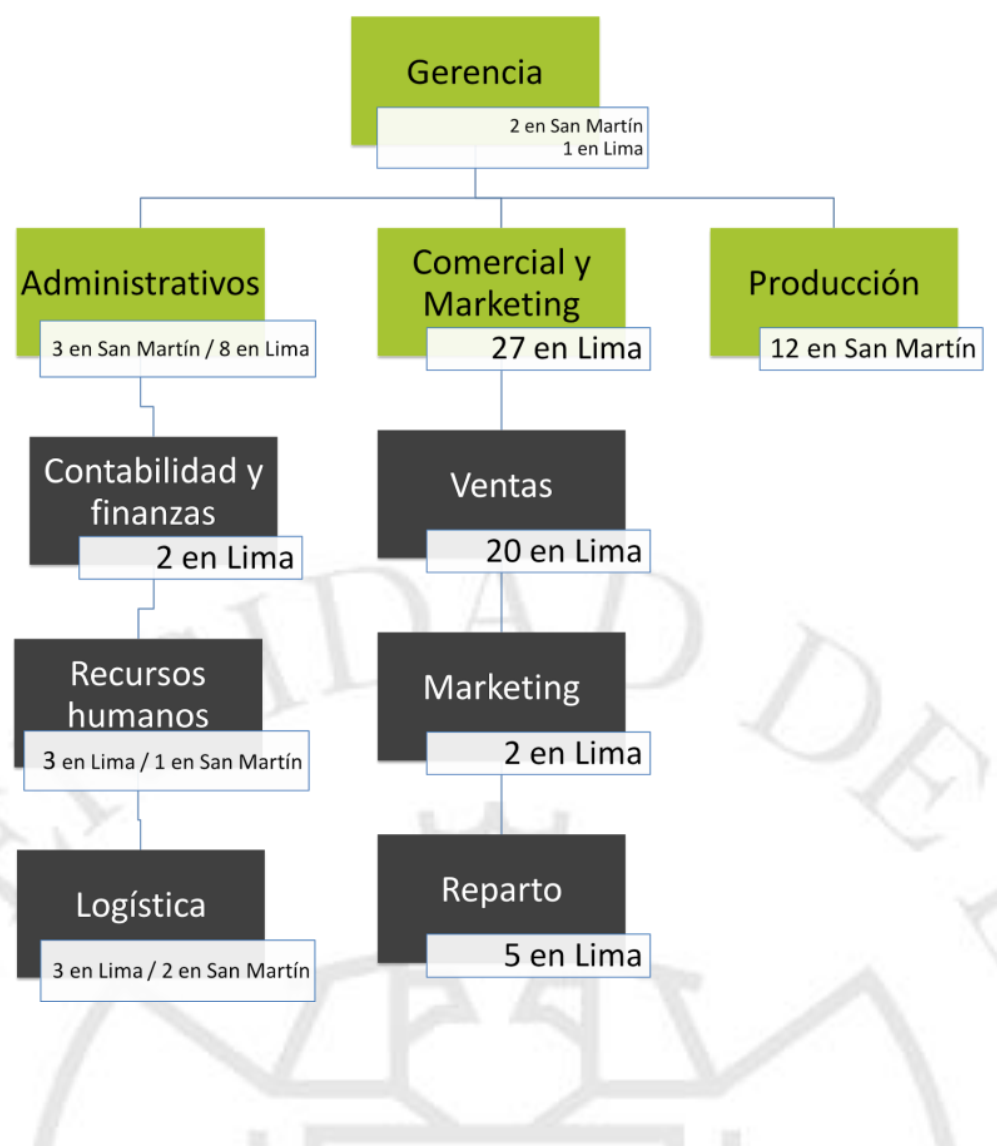

\section{Problemas del negocio}

a. Crecimiento de la empresa sin un propósito organizacional claro dada las diferentes necesidades y realidades de sus colaboradores en sus sedes de San Martín y Lima.

b. Carecimimento de un valor diferencial en la organización que inspire tanto interna como externamente.

c. Desconocimiento del público que consume su producto y sus características.

d. Pérdida de producción en el envío de productos a las ciudades de Arequipa, Trujillo y Cusco por la incorrecta manipulación del producto.

e. Caída de $10 \%$ en las ventas debido al crecimiento del mercado del aceite de coco en supermercados y tiendas. 


\section{CAPÍTULO II: EL ENTORNO}

\section{Macroentorno}

\subsection{Entorno político}

El país se encuentra sumido en una inestabilidad política resultado de los efectos del caso de corrupción Lava Jato, el cual involucra a un gran número de funcionarios de gobierno peruano, incluidos ex presidentes, quienes habrían recibido sobornos por parte de la empresa constructora brasilera Odebrecht a cambio de beneficios en licitaciones para obras y proyectos de construcción en el Perú.

En el ámbito legal, la industria del aceite de coco tiene un marco legal en el que se desarrolla. En este, encontramos algunas resoluciones, leyes y disposiciones que están relacionadas

a) Decreto Supremo No ${ }^{\circ} 006-2017-\mathrm{PCM}$

La Política Nacional de Protección y Defensa del Consumidor busca contribuir a un mayor y más eficaz nivel de protección de los derechos de los consumidores con equidad y mayor incidencia en los sectores de consumidores más vulnerables.

b) Política Nacional del Ambiente

Elaborada en el marco de la Ley General de Ambiente, Ley $\mathrm{N}^{\circ}$ 28611, esta política propicia y asegura el uso sostenible, responsable, racional y ético de los recursos naturales y del medio que lo sustenta, para contribuir al desarrollo integral, social, económico y cultural del ser humano, en permanente armonía con su entorno.

c) Ley de Seguridad y Salud en el Trabajo. Ley No 29783

d) Ley General de Inspección del Trabajo. Ley № 28806

e) Resolución Ministerial N 472-2017-PRODUCE

Proyecto de Decreto Supremo que aprueba el Reglamento de Fiscalización y Sanción de las Actividades de la Industria Manufacturera, Comercio Interno y Mipyme

f) Resolución Ministerial º 299-2017-PRODUCE

Proyecto de Decreto Supremo que aprueba el Reglamento del Decreto Legislativo $\mathrm{N}^{\circ}$ 1304, Decreto Legislativo que aprueba la Ley de Etiquetado y Verificación de los Reglamentos Técnicos de los Productos Industriales Manufacturados 


\section{1..2 Entorno económico}

Según el Banco Mundial, en el mediano plazo se espera que el crecimiento del país esté en un $4 \%$ gracias al aumento paulatino de las exportaciones y la fortaleza de la demanda interna. Este crecimiento podría verse afectado por la caída de precios en materias primas o un ajuste en las condiciones financieras internacionales.

La economía del Perú está expuesta a riesgos naturales, principalmente a los fenómenos climáticos como El Niño.

\subsection{Entorno social}

Según Ipsos Perú, al 2019 la población en el Lima será de 10 millones 378 mil habitantes, distribuidos en 2 millones 841 mil hogares y 3 millones 140 mil viviendas. Actualmente la tasa de crecimiento es positiva, con 102 mil habitantes anuales aproximádamente.

\subsection{Entorno tecnológico}

\section{Conectividad a internet}

La provincia de San Martin cuenta con cobertura de internet fijo y móvil gracias a las empresas proveedoras de la implementación de la red de fibra óptica a lo largo del país. En cuanto al internet fijo, Movistar ofrece un servicio de 200 Mbps prestado con tecnología Fibra Óptica - FFTH.

En cuanto al internet obtenido por telefonía móvil, la región cuenta con cobertura de parte de Movistar, Claro y Entel en las categorías de 2G, 3G y 4G.

\section{Uso de la tecnología en la empresa}

Cada vez más, la tecnología va adquiriendo importancia dentro de las empresas y la forma en la que se trabaja. Esta herramienta ofrece muchas ventajas como el incremento de la productividad y competitividad, reducción de costes y gestión de información.

Según Castro (2016), de cara a los colaboradores, la tecnología es capaz de potenciar la innovación a través de herramientas digitales que abren nuevos espacios y puntos de contacto. Además, gracias a la tecnología se rompen las barreras de la distancia física, pues a través de una videollamada o redes sociales se puede mantener el contacto entre colaboradores sin importar donde se encuentren.

Asimismo, a través del marketing digital, las empresas pueden mejorar su imagen y posicionamiento web en las diferentes plataformas digitales existentes. 


\subsection{Industria del aceite de coco}

\section{a. Contexto internacional}

\section{Mundo}

Según Tridge, plataforma de comercio global líder de productos alimenticios, energía y metales, Filipinas se encuentra en el primer lugar de acuerdo a la producción en el mercado global del aceite de coco con $35,7 \%$, seguido de Indonesia $(29,3 \%)$ e India $(12.7 \%)$.

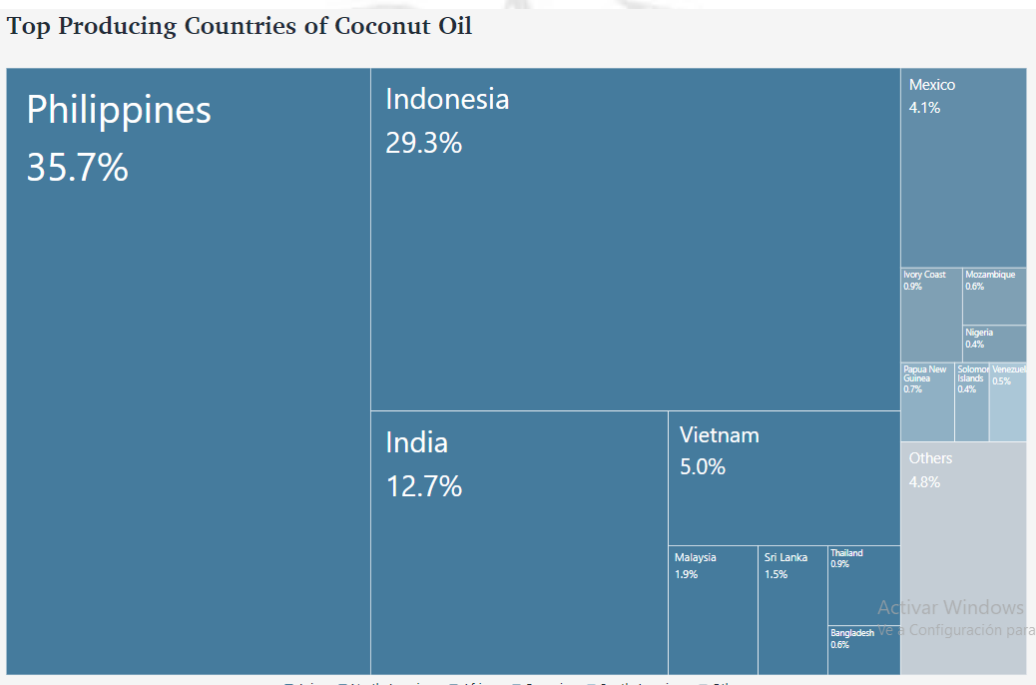

Figura 1: Países productores de aceite de coco. Tridge (2019)

Filipinas cuenta con un volumen de producción de $1.11 \mathrm{M}$ toneladas, total que ha ido disminuyendo en los últimos 5 años, seguido por Indonesia con $911.10 \mathrm{~K}$ de toneladas e India con $394.20 \mathrm{~K}$ de toneladas. De acuerdo al cuadro presentado a continuación frente a los principales países productores de aceite de coco, se puede identificar que la mayoría se encuentran al sur de Asia, a excepción de México en America. 


\section{Top Producing Countries of Coconut Oil}

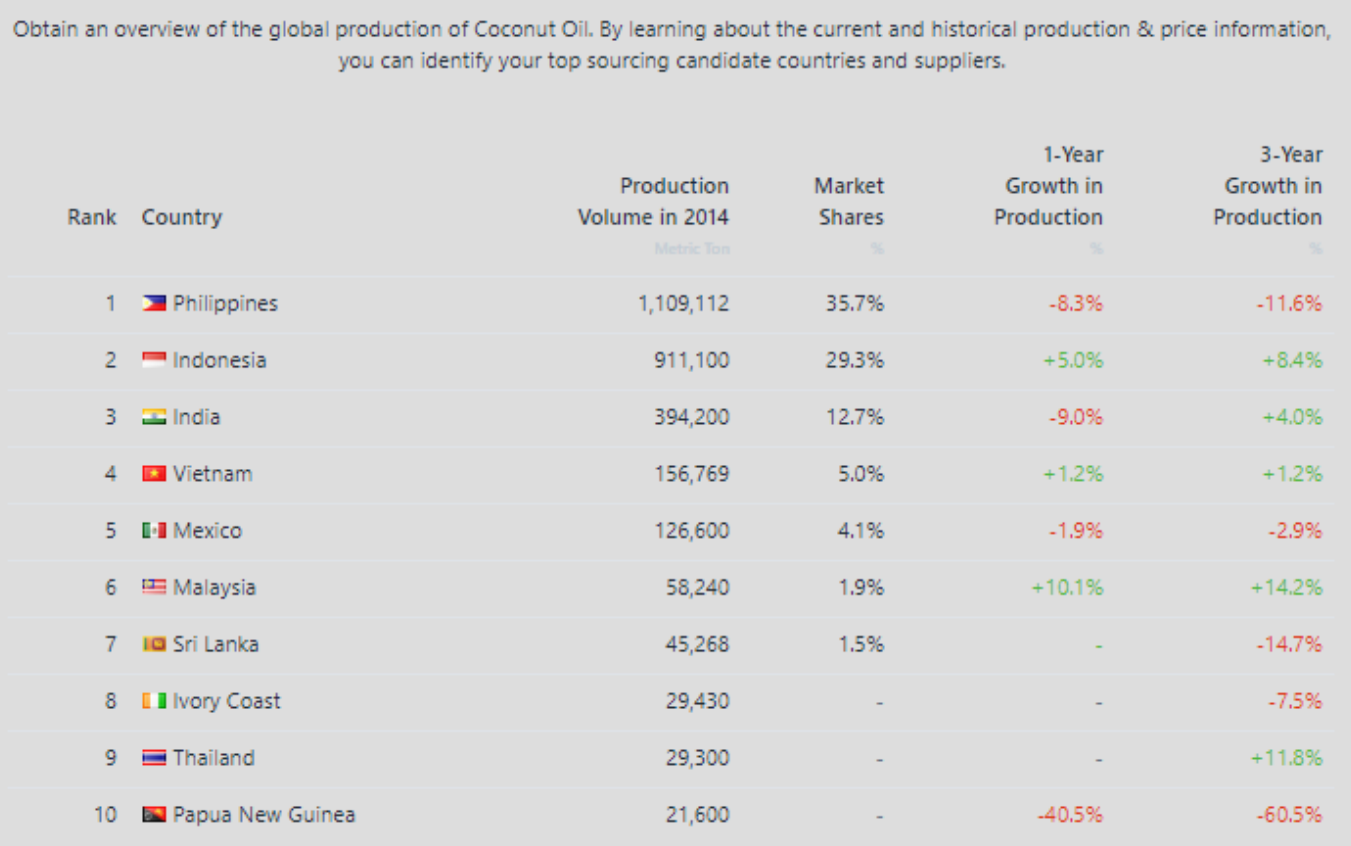

Figura 2: Principales países prodctores de aceite de coco. Tridge (2019)

En referencia al precio por kilo, el precio promedio estima en $\$ 1.66$, monto que se ha presentó una caída el mes pasado de $6.4 \%$.

Global Average Price

$\$ 1.66$

USD per $\mathrm{kg}$

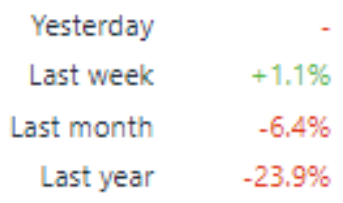

Last year
$-23.9 \%$

Figura 3: Promedio del precio anual del aceite de coco. Tridge (2019)

El volumen de producción global se ha mantenido estable desde 1995 a la fecha, presentando un total de $3.11 \mathrm{M}$ toneladas en el 2014.

Según el Observatory of Economis Complexity (OEC), en el 2017 frente a la importación, se reconoce a Estados Unidos en el primer lugar con 18\%, seguido de China 14\% y Países Bajos con $12 \%$. En el caso de las exportaciones, Indonesia presenta el mayor porcentaje global con $42 \%$, seguido por Filipinas con $20 \%$ y Malasia con $16 \%$.

Según la FAO, la Organización de las Naciones Unidas para la Alimentación y la Agricultura, en 2013 se cultivaron en el mundo 63 millones de toneladas de coco, fundamentalmente en Indonesia, Filipinas, la India y Brasil. Europa es el único continente en el que no se siembra. 
Por su parte, el Centro de Promoción de Importaciones de países en desarrollo (CBI), reconocida agencia adscrita al Ministerio de Asuntos Exteriores de Holanda, reconoce que las oportunidades de exportación del aceite de coco a Europa aumentan. Ello se debe a una alta demanda combinada con las dificultades para la producción del coco.

Asimismo, reconoce que tanto Filipinas como Sri Lanka son los exportadores más grandes de aceite de coco virgen a Europa. Además, hace referencia a La Comunidad Internacional del Coco (ICC); organización intergubernamental ubicada en Indonesia creada bajo la Comisión Económica y Social de las Naciones Unidas para Asia y el Pacífico (UN-CESPAP) y Las Asociaciones Unidas de Cocos de Filipina (UNAP).

Dada la extensión de la ICC, integrada por 18 países asiáticos y del Pacífico, la organización representa alrededor del $90 \%$ de la producción mundial del coco y las exportaciones de productos de coco (El Centro de Promoción de Importaciones de los países en desarrollo, 2010).

\section{Latinoamérica}

El informe realizado por Eurimonitor International para la Organización de Alimento y Agricultura de las Naciones Unidas mide la producción del aceite de coco a nivel mundial y, en el caso de Latinoamérica, se cuenta con data desde el 2013 hasta el año pasado. Si bien la producción del aceite de coco ha disminuido relativamente desde el 2013 (176.6 mil toneladas anuales) hasta el año pasado, se puede observar que en estos años ha mantenido una estabilidad, situación que se espera mantener en los próximos años. En el 2018, la producción de aceite de coco en Latinoamérica fue de 170.8 mil toneladas.

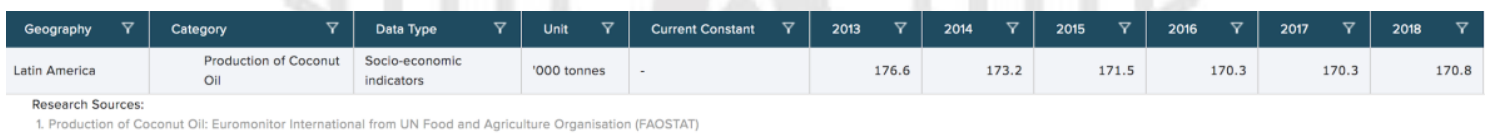

Figura 4: Producción del aceite de coco en Latinoamérica. Euromonitor International (2018)

En cuanto a la importación y exportación del aceite de coco, según el OEC, en el 2017 frente a la importación se obtuvo un valor de $\$ 333 \mathrm{M}$ y frente a la exportación un valor de $\$ 133 \mathrm{M}$. Se reconoce a Brasil como el principal importador con una participación del $82 \%$, seguido de Argentina con 8,2\% y Colombia con 5.5\%. Perú tiene una participación del $0.2 \%$ con un valor de importaciones de $\$ 674 \mathrm{~K}$. 


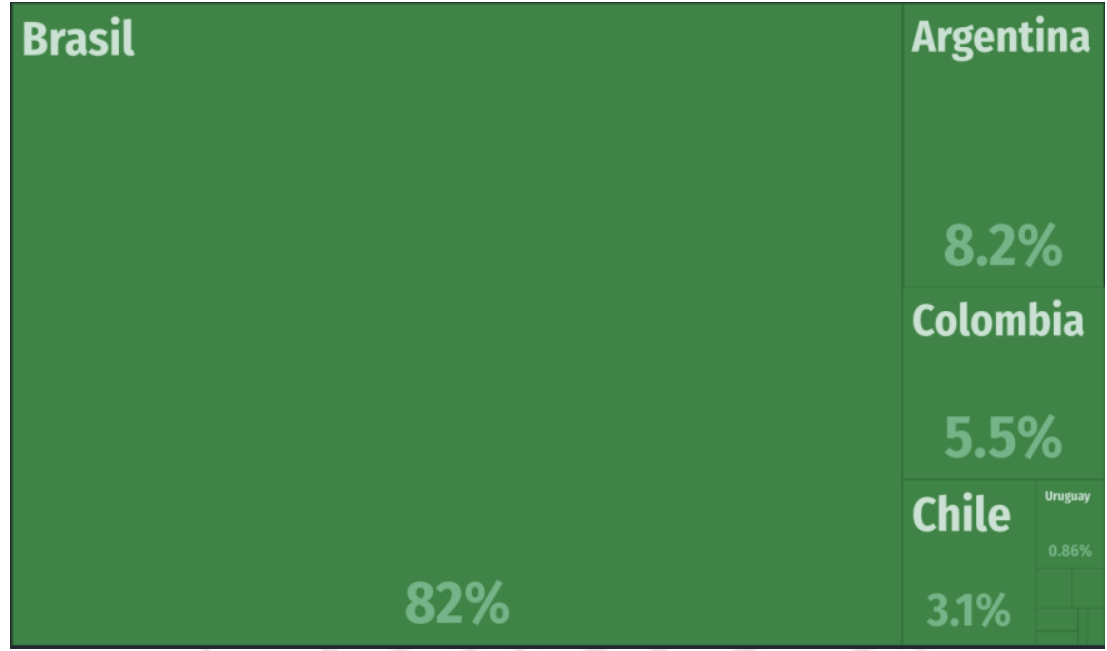

Figura 5: Importaciones del aceite de coco en el mundo. OEC (2017)

En el caso de las exportaciones, Colombia presenta el mayor porcentaje de participación a nivel latinoamericano con $70 \%$, seguido por Ecuador con $21 \%$ y Perú con $4 \%$ y un valor de exportaciones de $\$ 5.27 \mathrm{M}$.

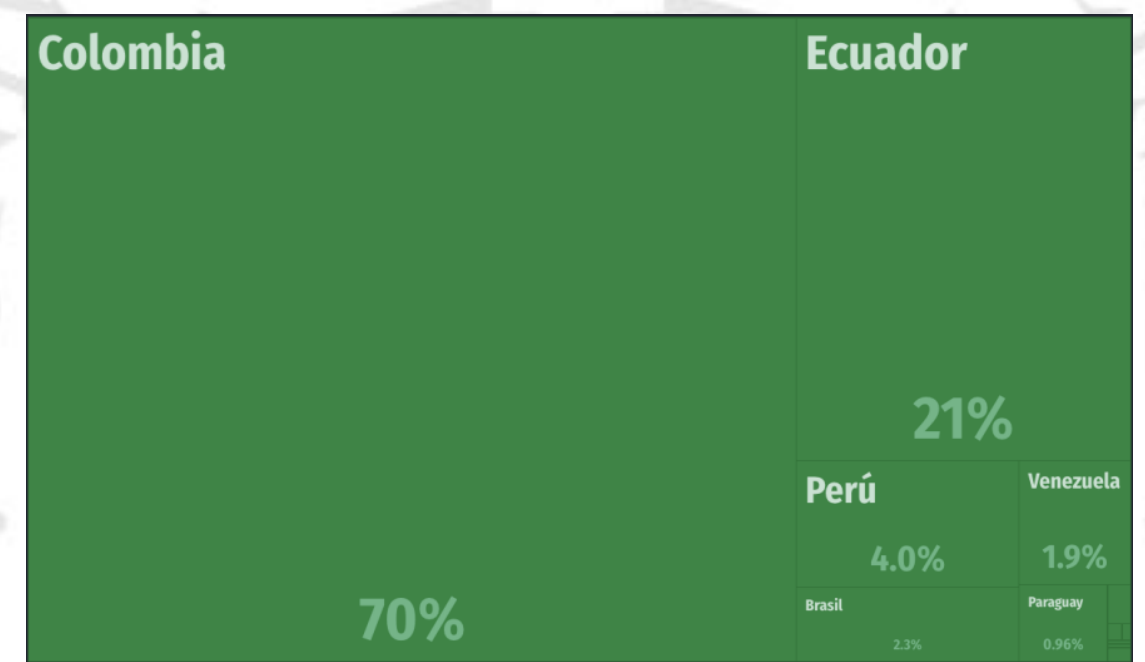

Figura 6: Exportaciones del aceite de coco en el mundo. OEC (2017) 


\section{b. Contexto nacional}

\section{Sector manufacturero}

La industria del aceite de coco se encuentra dentro del sector manufactura, al ser un aceite vegetal catalogado como bien de consumo.

Según Peñarada, la Cámara de Comercio de Lima (CCL) estimó que en el 2018 el sector manufactura alcanzaría un crecimiento de $3.7 \%$, su mayor tasa en cinco años. La aceleración del consumo privado motiva la producción de manufactura orientada al consumo masivo.

A febrero del 2019, el sector manufactura representó el $16.52 \%$ de la producción nacional (INEI, 2019). Se registró una disminución de $-1.28 \%$ con respecto al año anterior, sin embargo, el subsector fabril no primario creció en $1.46 \%$ impulsado por la actividad productora de bienes de consumo, intermedios y de capital.

En la Amazonía peruana se concentra la mayor producción de coco a nivel nacional. Al año 2017, la región San Martin concentra el mayor volumen de producción de coco con 11,579 toneladas producidas. Estas representan el 35\% de la producción nacional que ascendió a 32,646 toneladas a diciembre de ese año. Le siguen la región Loreto con 9,569 toneladas y Ucayali con 6,770 toneladas (MINAGRI, 2017).

El mercado peruano presenta una demanda insatisfecha de bienes de consumo de aceites vegetales, de los cuales el $0.04 \%$ de la producción nacional corresponde al aceite de coco. Para satisfacer la demanda, es necesaria la importación de otros países productores (MINAGRI, 2012), por lo que a octubre del 2017 se importaron 13,670 kilogramos de aceite de coco.

Según la OEC, al 2017 Perú importaba aceite de coco principalmente desde Ecuador (54\%), seguido por países del continente asiático como Malasia (29\%), Filipinas (5.2\%), y Sri Lanka (4.3\%); y Estados Unidos (3.3\%). Se exporta en menor medida al continente europeo a Bélgica-Luxemburgo (0.88\%) y España $(0.54 \%)$.

Según Veritrade, en los últimos 5 años se importó un total de US\$150,256 que corresponden a una cantidad de 27,301 kilogramos.

En cuanto a la exportación del aceite de coco peruano, al 2017 se exporta principalmente a México (51\%); en latinoamérica a Chile (17\%), Brasil (15\%), Colombia (9.2\%) y Ecuador (4.8\%), y en Europa se exporta a España (3,3\%).

Según Veritrade, en los últimos 5 años se exportó un total de US\$150,256 que corresponden a una cantidad de 27,301 kilogramos. El consumo per capita de aceites en el Perú es uno de los más bajos de la región, alcanzando un promedio $10 \mathrm{~kg} / \mathrm{anuales}$, mientras que en países región andina es más alta.

En la industria de consumo masivo, la rama de elaboración de aceites y grasas de origen vegetal y animal creció en $9,05 \%$ en el 2017, por mayor elaboración de aceite vegetal y diversas mantecas para el consumo local y externo (INEI, 2017). 


\section{Deforestación}

Según el Programa Nacional de Conservación de Bosques (PNCB) del Ministerio del Ambiente, el Perú es el país con la segunda mayor extensión de selva amazónica. En promedio, se pierden más de 120 mil hectáreas cada año, y en el 2018 , el $71 \%$ de la deforestación de bosques se concentró en la selva peruana que perdió 140,185 hectáreas (Gestión, 2018), de las cuales 3,000 corresponden a la región de San Martín.

Según César Calmet, coordinador ejecutivo de la PNCB, entre las principales causas de este fenómeno se encuentran la agricultura, la ganadería, la tala ilegal de árboles, la minería ilegal y el narcotráfico. Los agricultores queman bosques para limpiar las tierras para el cultivo, rotando de una parcela a otra una vez que esta se vuelve infértil.

Si bien se están realizando esfuerzos para reforestar la región amazónica, como la iniciativa presentada por el Fondo Mundial para la Naturaleza (WWF) para plantar 155 mil árboles en el 2018 y recuperar 140 hectáreas de la Amazonía que equivalen al $0.1 \%$ de la superficie deforestada, estos aún resultan insuficientes para hacer frente a este problema.

Según el Servicio Nacional Forestal y de Fauna Silvestre (SERFOR), los ecosistemas en el Perú son altamente vulnerables por efectos del cambio climático. Este factor, sumado al fenómeno de la deforestación, hace que la sensibilización de la población sobre el valor de nuestros bosques sea vital.

\subsection{Tendencias}

\section{Crecimiento del mercado de agricultura ecológica}

La empresa de estudios de mercado Ecovia Intelligence estima que el mercado mundial de alimentos orgánicos alcanzó 89.700 millones de dólares USA en 2016 (más de 72 mil millones de euros). Estados Unidos es el mercado líder con 38.900 millones de euros, seguido de Alemania (9.500 millones de euros), Francia (6.700 millones de euros) y China (5.900 millones de euros).

De acuerdo al estudio realizado en el 2018 sobre agricultura orgánica a nivel mundial aplicando información mundial al año 2016, FiBL e IFOAM, instituciones importantes de investigación en agricultura orgánica indican que a nivel mundial se gestionaron 57,7 millones de hectáreas a finales de 2016, lo que representa un crecimiento de 7,5 millones de hectáreas con respecto a 2015, el mayor crecimiento registrado.

En América Latina se encuentra el 12 por ciento de la tierra agrícola orgánica mundial con 7,1 millones de hectáreas.

El mercado global de alimentos y bebidas orgánicas creció un $10 \%$ entre 2015 y 2016, según FiBL e IFOAM en un estudio en el 2018. Indicó además que ha alcanzado los USD 89.700 millones. Asimismo, según la consultora inglesa Ecovia Intelligence (Organic Monitor), 2018, señala que el mercado era de 21.000 millones de dólares en 2001 y de 
89.700 millones en 2016, representando un crecimiento de $427 \%$. Por otro lado, la superficie en los mismos 15 años aumentó en 40,5 millones de hectáreas, es decir, un $334 \%$.

En este sentido, se presenta el desarrollo de la agricultura orgánica, que promueve y enriquece la biodiversidad, ciclos biológicos y la actividad biológica del suelo, ofreciendo un producto más seguro para el consumidor (OTA, 2002). Son los alimentos orgánicos, también llamados ecológicos o biológicos, los que se caracterizan principalmente por ser alimentos sanos y de calidad y por ser controlados en todas las etapas del proceso productivo desde el origen (CAAE 2013; Hartman Group 2010), volviéndolos significativos frente al consumo de productos industriales.

En el caso peruano, existe una oportunidad para posicionarse como país orgánico gracias a sus características geoestratégicas como país marítimo, andino, amazónico y con proyección bioceánica (Proexpansión 2014), ello acompañado del reconocimiento legal por el Estado de la agricultura orgánica en el 2001, aspecto que acrecenta las oportunidades de los agricultores de este ámbito (RAAA 2008).

Según una entrevista realizada por El Comercio en el 2015 a la organización de promoción del mercado ecológico, Ecológica Perú, el consumo de alimentos organicos se ha incrementado en 10 años en un 70\% apuntando al crecimiento. Eso se debe a un mayor interés de alimentos orgánicos, es decir, libres de pesticidas y fertilizantes artificiales, volviendo el consumo más saludable.

Esta tendencia a incrementando la creación de bioferias, ecoferias o mercados saludables, espacios de crecimiento para productores y consumidores ecológicos. La Bioferia, es la primera feria de alimentos orgánicos en el país, punto de venta que cumple 20 años en diciembre de este año. Otras bioferias muy visitadas se encuentran en Surquillo, La Molina y Magdalena.

El objetivo de estas bioferias es darle la oportunidad a los productores de campo o procesadores para vender sus productos y ser promoteres de un consumo saludable y responsable. La venta es consecuencia natural luego de que el usuario se informa, se sensibiliza y se convence de las ventajas del producto ecológico (LEISA 2015, APEGA 2016) 


\section{Consumo sano y responsable}

Según FiBL, los factores que explican la preferencia de los consumidores por productos orgánicos son aquellos relacionados con la salud de las personas (ausencia de plaguicidas, hormonas, antibióticos, OGM) y la protección del medioambiente.

La tendencia al consumo orgánico se encuentra en crecimiento debido al cambio en la visión de la responsabilidad medioambiental y alimentación saludable.

Según el estudio de Datum sobre "Vida Saludable" del 2018, realizado a hombres y mujeres de 18 a 70 años a nivel nacional, la gran mayoría de peruanos asocia este concepto con "comer sano" (68\%). Los limeños y citadinos lo asocian también con "hacer deporte" (58\%) lo cual estaría relacionado con salud física y "pasar tiempo con la familia" $(56 \%)$ que podría estar relacionado con la salud afectiva-emocional.

Kantar WorldPanel, compañía mundial de datos, insights y consultoría, reconoce que el consumidor peruano busca alimentarse de manera más sana, natural y balanceada, buscando mantenerse informado sobre los componentes de los productos que consume. Ello a llevado a que las organizaciones se alineen y ofrezcan alternativas más saludables.

Según el estudio Consumer Watch de la consultora, en el 2017 el 34\% de los hogares limeños decidió hacer cambios en su alimentación debido a la preocupación por su salud.

Es así que, de acuerdo a otro estudio reciente sobre Salud y Etiquetado realizado por Kantar, el 54\% de hogares peruanos se considera "saludable" o "muy saludable". Para este estudio, se tomó como muestra representativa de 1800 hogares a nivel nacional y se cruzó con un reporte de consumo de hogares que incluye 80 categorías de consumo masivo.

En el contexto peruano actual, la aprobación en marzo del 2019 del uso obligatorio de los octógonos de advertencia en los alimentos procesados, incentivará, como menciona Max Vidal, socio de Axer Consultores en una nota del diario Gestión del 2019, a que "los consumidores sean más críticos con las marcas y estén alertas al contenido de los productos. Ello los llevará a cambiar sus hábitos alimenticios". De esta manera, se identifica la tendencia del consumidor que busca estar más informado.

Según un estudio realizado en marzo de este año por la consultora a limeños de 20 a 59 años en marzo de este año, el 63\% de consumidores limeños afirma que reducirá el consumo de alimentos etiquetados con octógonos; mientras que un $21 \%$ dejará de consumirlos. No obstante, es importante mencionar que el 50\% de consumidores limeños no ha escuchado sobre los octógonos de advertencia en los alimentos procesados. Este porcentaje se irá reduciendo ante la difusión de la información de manera responsable por las entidades involucradas. 


\section{Impacto de los octógonos en hábitos de consumo de limeños}

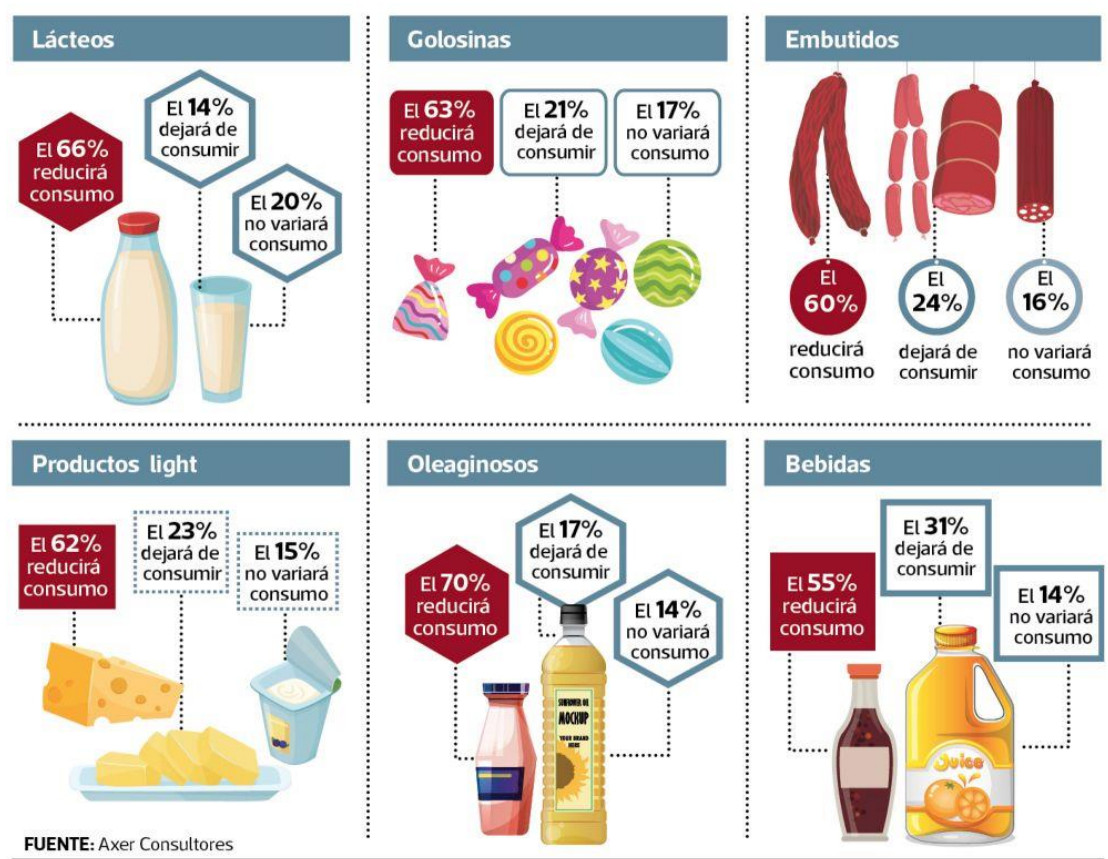

Figura 7: Impacto de los octógonos en hábitos de consumo de limeños. Axer Consultores (2019)

\section{Cuidado personal y cosmética}

De acuerdo a dos notas publicadas en el 2017 y 2018 sobre tendencias en belleza por Ainia, centro de investigación y desarrollo tecnológico Español, el concepto de mejora de estilo de vida y el bienestar aplicado a la alimentación está también siendo tendencia en el mercado cosmético, dada la relación estrecha con entre la estética, lo natural y la apariencia. Los productos cosméticos naturales son aquellos que contienen ingredientes obtenidos a partir de fuentes naturales, están libres de productos químicos o plaguicidas y son percibidos como más saludables.

Es así que el bienestar se presenta también con uno de los principales insights de consumo en el ámbito de la cosmética. Por otro lado, se identifica que los ingredientes utilizados en la cosmética ecológica son más beneficiosos para la salud de la piel, ejerciendo, además, un consumo más respetuoso con el medioambiente. 


\section{Marketing Verde}

El concepto del marketing verde se conceptualiza en la perspectiva social y empresarial.

Por un lado, la social busca estimular ideas y conductas medioambientales deseables entre los ciudadanos, que propicien comportamientos sociales beneficiosos para la comunidad. Por otro lado, la perspectiva empresarial motiva el compromiso con el medioambiente en las organizaciones y que, desde el proceso de planificación, implementación y control del márketing mix, se procure la satisfacción de los clientes con el menor impacto negativo sobre el ambiente (Mad Comunicación, 2007).

A medida que el consumidor se encuentre más informado, irá exigiendo productos que respeten el medioambiente en cada paso de la cadena productiva. Frente a ello Calomarde (2002), menciona que las empresas que no se ajusten a estos cambios perderán competitividad y serán reemplazadas por aquellas que sí entregaron un "producto aumentado", pues la cuestión ambiental es un beneficio adicional proporcionado a los consumidores.

Las estrategias del marketing mix ecológico reflejan la importancia del mayor cuidado medioambiental del producto durante las etapas del producto, precio, plaza, promoción y todo el ciclo de vida, incentivando a la reutilización o el reciclado del mismo en la fase final.

Frente a la distribución comercial del producto ecológico, es importante que la organización pueda reconocer los lugares de compra del consumidor ecológico y dónde se encuentra geográficamente, a fin de para brindarle facilidades y accesibilidad (Izaguirre, Fernández-Sainz, Vicente, 2013)

En muchos casos, aunque exista intención y motivación para la compra ecológica, ésta no puede llevarse a cabo por la escasa disponibilidad de productos ecológicos. (Rodríguez, 2006; Vermeir y Verbeke, 2006; Francis y Davis, 2015).

Asimismo, de acuerdo al precio, los productos ecológicos suelen tener un coste superior a los convencionales, lo que puede ser una de las barreras más importantes frente mantener un comportamiento ecológico. Para reducir este obstáculo, el consumidor debe, por un lado, percibir que los beneficios que se derivan del consumo de productos ecológicos son mayores que los esfuerzos (económicos y no económicos) en los que hay que incurrir para su adquisición y, por otro lado, satisfacer sus necesidades básicas a la hora de decidir la compra para obtener una percepción favorable.

Asimismo, resulta fundamental que el consumidor reciba información del producto ecológico, lo identifique y reconozca en su consumo el valor medioambiental y las ventajas para su salud (Hamann, 2013 e Izaguirre 2016)

Ante lo mencionado anteriormente, el rol de la comunicación se torna escencial pues la información brindada, además del aspecto comercial, debe centrarse en el valor del producto, educando al cliente e introduciendo nuevos comportamientos de compra orientados al compromiso con el ambiente, así como estableciendo y manteniendo una credibilidad ecológica para el producto y la empresa. Estos ecomensajes deben ser dirigidos hacia los grupos de interés en los que impacta la organización, involucrándolos 
y motivándolos a aplicar el contenido y reconocer su rol en el mercado orgánico y el medioambiente. Asimismo, las organizaciones de productos ecológicos deben identificar los canales y espacios de comunicación a los que recurre el consumidor, a fin de brindarles información cercana y relevante; un estudio de Young, Hwang, McDonald y Oates (2010), revela que la falta de tiempo para informarse, tomar la decisión, y llevar a cabo la compra es una de las barreras al consumo de productos ecológicos (Hamann 2016, Izaguirre 2013 e Izaguirre 2016)

Frente al desarrollo de prácticas de marketing verde, Grant (2007) en su libro The green Marketing Manifesto, destaca cinco puntos para su aplicación eficaz.

De esta manera, los siguientes conceptos invitan a aplicar el marketing verde como un estilo de vida; un cambio en el consumo que impacte en la sostenibilidad, desarrollo social y ambiental. Asimismo, el crecimiento de consumidores ecoamigables informados y educados que fomenten la creación de productos innovadores.
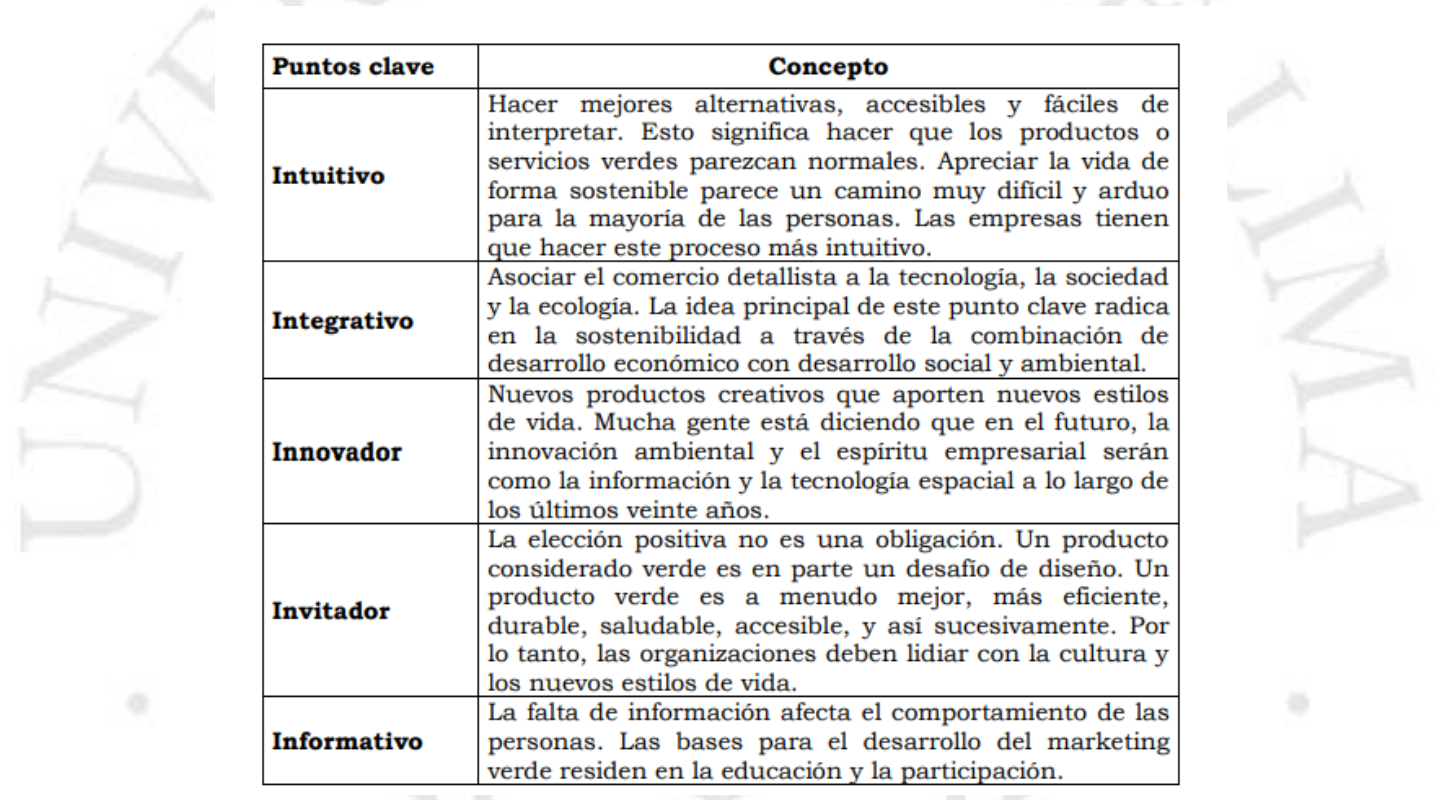

Figura 8: Los cinto puntos del marketing verde. Crassous y Grassmann (2011)

Esta concepción del marketing verde se da con el objetivo de evitar errores y greenwashing. Este último término se describe como una falsa estrategia de marketing donde las empresas denominan a sus productos como sostenibles y orgánicos, apalancándose en sus iniciativas de responsabilidad social y promoción amigable con el medioambiente, cuando en realidad no lo son.

Es así que en un artículo realizado por Conexión Esan en el 20128 se indica que actuamente la atención detallada a las etiquetas de los productos, así como las garantías y certificaciones de calidad de los mismos se tornan importantes para evitar publicidad engañosa y dañar la reputación del crecimiento de productos orgánicos. 


\subsection{El consumidor}

Hoy en día existe mayor conciencia sobre una alimentación más saludable. Izagirre et al. (2013) reconoce la aparición de un nuevo tipo de consumidor que se caracteriza por ser más consciente de las consecuencias medioambientales frente aquello que consume, ya que está sensibilizado por los efectos negativos en el ecosistema.

Además, se presentan comportamientos con distintos enfoques como la compra de productos ecológicos, reciclaje, voto, activismo u otros (Izagirre et al., 2013).

Según un artículo del 2017 en el diario El Economista, en el Perú, los millennials muestran una tendencia a lo natural, prefiriendo los productos orgánicos, ecológicos, más artesanales y con sabores más intensos.

Frente a ello, en una infografía realizada por Millennial Marketing indica la siguiente información sobre esta generación, nacida entre 1979 y los 2000:

- $\quad 30 \%$ consume productos orgánicos que se encuentren certificados. Prefieren la comida natural que procesada.

- 8 de cada 10 millennials desea saber la historia detrás de sus alimentos y conocer más sobre su constitución y creación.

- Mayor importancia de un empaque eco-amigable que refleje el estilo de vida y actitudes referentes a la alimentación, salud y medioambiente.

- Además de la nutrición, los alimentos son vistos por el componente de entretenimiento que le genera al usuario y la autoexpresión.

Según el informe "Tendencias en salud y alimentación" del 2008, realizado por Ipsos Perú, existe una predisposición positiva del 53\% de encuestados (500) hacia la información de cuidado nutricional y un $61 \%$ hacia la preocupación por el medioambiente. No obstante, el $21 \%$ de las personas encuestadas encuentran una barrera para mejorar sus hábitos de alimentación dado los nuevos informes complejos que se van creando. Asimismo, el $22 \%$ indica que está muy ocupado para tener una dieta saludable.

\section{Características del perfil}

En primer lugar, de acuerdo al informe del "Perfil del adulto joven peruano" realizado en el 2018 por Ipsos Perú, se tómo como base a 1024 jóvenes. En el Perú 6,267,908 corresponden al segmento de 21 a 35 años, conocidos como millennials. De la población indicada, el $48 \%$ pertenecen al género masculino y $52 \%$ al femenino. En cuanto al rango de edad, 37\% pertenecen al rango de 21 a 25 años, 33\% de 26 a 30 años y $30 \%$ de 31 a 35 años.

En cuanto al nivel socioeconómco, $3 \%$ pertenecen al nivel A, $17 \%$ al B, $33 \%$ al C, $29 \%$ al D y $18 \%$ al E.

Frente a sus estudios, $17 \%$ han concluido sus estudios superiores, $7 \%$ cuentan con universidad incompleta y $22 \%$ tienen estudios técnicos completos. 
De acuerdo a sus ingresos, las remuneraciones quincenales o mensuales son la principal fuente de ingresos para los adultos jóvenes $(59 \%$, ), seguido por el salario diario o semanal $(28 \%)$.

Referente a los medios de entretenimiento, manteniendo como base a 1024 entrevistados, el principal canal es la televisión (55\%), seguido por chatear en redes sociales (32\%) y conversar en WhatsApp (29\%). Las actividades como el uso de redes sociales, WhatsApp, Youtube o Spotify son predominantes en adultos jóvenes de NSE AB y del rango de edad de 21 a 30 años.

Asimismo, 3 de cada 4 jóvenes adultos es miembro de una red social, siendo Facebook (76\%) y WhatsApp (52\%) las más populares, seguido de Instagram (29\%). La tendencia de pertenecer a una red social es mayor en Lima (85\%). Asimismo, es superior en los NSE A (95\%), B (96\%) y C (86\%).

En segundo lugar, en el estudio "Medios tradicionales: Hábitos y actitudes" realizado en el 2017, se identifica que, de la base total de 351 limeños entrevistados, el NSE A cuenta con 5\% de lectores de diarios, NSE B 21\%, NSE C 42\%, NSE D $24 \%$ y NSE E $8 \%$. Además, El Comercio y Gestión son los diarios más leido en el NSE A con un $75 \%$. En el caso del rango de edad de 25 a 39 años, el mayor consumo se presenta por el diario Trome (56\%) y El Comercio (35\%). Asimismo, El Comercio es el diario líder en la versión web (46\%), así como el más utilizado mediante su aplicación (45\%).

En tercer lugar, en el informe "Hábitos y actitudes hacia los medios de comunicación alternativos" del 2015, utilizando como muestra a 517 entrevistados, se reconoce que los medios publicitarios con mayor agrado en los niveles NSE A, B y C son los videos. En cuanto a la edad de 25 a 39 años, se presenta mayor gusto en las actividades culturales o eventos deportivos (20\%), seguido por los videos (16\%).

De acuerdo a los elementos publitarios, los que más le agradan al NSE A son el catálogo (20\%) y la pantalla electrónica (Led) (17\%); en el caso del NSE B, la preferencia es la inversa presentando un $24 \%$ y $15 \%$, respectivamente. En cuanto a la edad de interés (25 a 39 años), se encuentra un mayor agrado en pantallas electrónicas (22\%), mensajes colgantes o pestañas de descuentos, ofertas de un producto (20\%) y catálogos (18\%).

En cuanto a los establecimientos que se suelen visitar, el total de entrevistados (517) indicó, a las bodegas (56\%) en primer lugar, seguido por supermercados o hipermercados $(53 \%)$ y mercados de barrio (42\%). Frente a los establecimientos que visitan con mayor frecuencia, se encuentra el mercado de barrio en primer puesto (29\%), supermercados o hipermercados $(26 \%)$ y bodegas $(25 \%)$. Según el informe, los tres atributos que atraen más de los avisos publicitarios en los puntos de venta son la creatividad/originalidad $(35 \%)$, las letras grandes $(31 \%)$, los colores llamativos $(22 \%)$ y fotografías empleadas $(22 \%)$.

Sobre la publicidad en internet, los elementos publicitarios de mayor agrado en la muestra encuestada (345) son el video (53\%), redes sociales (22\%) y banners en aplicaciones móviles (18\%), en ellos, los atibutos que más atraen son la creatividad/originalidad (51\%), que tenga explicación resumida de las ventajas (37\%) y el uso de fotos (32\%).

De acuerdo a la publicidad BTL, se presenta una mayor inclinación a la prueba de productos $(43 \%)$ y actividades culturales o eventos deportivos (25\%). 
En cuarto lugar, en el informe "Perfil del usuario de redes sociales" del 2018, de 367 personas encuestadas del NSE AB, 29\% siguen a influencers. Frente al nivel de uso en redes sociales; en primer lugar, el perfil demográfico del usuario de Facebook corresponde a un millennial de 37 años, soltero y que trabaja de forma dependiente. Según la muestra de 743 entrevistados, se utiliza principalmente esta red social para chatear (79\%), comentar (45\%) y dar "Me gusta" (41\%); en segundo lugar, el usuario activo de Instagram es un millennial de 30 años que pertenece a los NSE AB y que trabaja de forma independiente. Con una base de 153 entrevistados, la red social se emplea principalmente para publicar fotos y videos (74\%), mirar publicaciones (66\%) y dar "Me gusta" (52\%).

\section{Microentorno}

\subsection{La empresa}

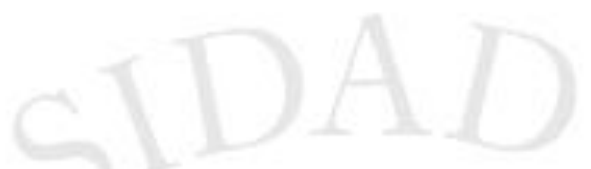

La empresa va a cumplir 20 años en el mercado de venta de aceite. No obtante, hasta el momento no ha logrado construir un propósito que inspire tanto hacia adentro como hacia afuera. Es así que, los socios de la organización han dedicido emprender una serie de cambios organizacionales con el objetivo de lograr el crecimiento del negocio.

\subsection{El producto y proceso}

Segú la Organización de las naciones unidas para la Alimentación y la Agricultura, el aceite de coco proviene de la fruta tropial coco. Esta fruta crece en cocoteros de hasta $30 \mathrm{~m}$ de alto y requieren de un clima cálido constante y libre de heladas, abundante lluvia y sol.

De acuerdo a los tipos de cocos se presentan:

- Los gigantes: utilizados para la producción de aceite y para consumirlos de manera fresca principalmente. Tienen un alto contenido de copra (pulpa seca del coco) de buena calidad.

- Enanos: utilizados para la producción de bebidas envasadas por su buen sabor. La copra de este tipo de cocos no es de muy buena calidad.

- Híbridos: cruce entre ambas variedades. Tienen un sabor agradable, copra de buena calidad y abundancia.

En cuanto a su uso, el producto puede ser empleado de manera alimenticia e industrial, siempre mantienendo su naturalidad. Algunos beneficios de su aplicación son:

Alimenticio:

- Combate el colesterol alto, tiroides - hipotiroidismo e hipertiroidismo, Alzheimer, demencia senil, diabetes, infecciones urinarias, pie de atleta, candidiasis, quemaduras, hongos en la piel y cuero cabelludo.

- Su composición de ácidos grasos permite que el cuerpo lo metabolice con mayor rapidez como energía, facilitando la digestión y la pérdida de grasa corporal.

- Favorece la formación de cuerpos cetónicos que generan sensación de saciedad. 
Industrial:

- Aporta diversas propiedades y beneficios a la piel como hidratante, desinfectante, antiarrugas, protector, calmante, antiinflamatorio y revitalizante.

- Se puede utiliza para cocinar y freir ya que su alto contenido de grasas saturadas lo hace resistente a las temperaturas.

- Mejora la salud bocal.

Por otro lado, el aceite de coco es una grasa vegetal por lo que su consumo excesivo puede elevar el colesterol LDL (malo). No obstante, también causa un aumento en el colesterol HDL (bueno), mejorando la calidad y tipo de colesterol en el cuerpo.

Frente a ello la Agencia de Consumo, Seguridad Alimentaria y Nutrición (AECOSAN) recomienda que el consumo diario de grasas no supere el $30 \%$ de la energía total consumida, con un máximo del $7 \%$ de grasas saturadas.

\section{Obtención del aceite de coco}

Coco Peruano apuesta por la creación de un aceite de coco orgánico, empleando así el Método Directo de Micro Expulsión para la obtención del producto, lo que hace que se caracterice por su limpieza, frescura y naturalidad. Además, el sabor y todos los beneficios que el aceite de coco puede ofrecer se conservan debido a que es prensado en frio, sin refinar y no pasa por filtros. Gracias a ello y la fertilidad de la selva peruana en donde se produce, es que se mantiene como un producto orgánico de calidad.

Según la organización Greenpeace, la agricultura ecológica nace del respeto a las dinámicas naturales de los ecosistemas y de la preservación del equilibrio biológico. La agricultura ecológica garantiza productos saludables para una producción actual y a largo plazo, ya que protege el suelo, el agua y el clima, promoviendo la biodiversidad.

\subsection{Público interno}

La empresa "Selva \& Salud" cuenta con 53 colaboradores en total. 17 en San Martín (12 trabajadores de campo, 3 administrativos, 2 socios) y 36 en Lima (22 vendedores, 8 administrativos, 5 asistentes y reparto, 1 socio). El $60 \%$ de los colaboradores son mujeres.

El $30 \%$ de los colaboradores tienen entre 18 y 25 años, el 50\%, entre 26 y 38 años y el $20 \%$ más de 39 años.

En el año 2010 se aperturó la primera tienda en Lima, en el distrito de Surquillo, más la empresa ha crecido sin un propósito organizacional claro, diferenciador y que inspire hacia adentro y hacia afuera de Selva \& Salud.

Dentro de las dificultades identificadas se reconoce que los trabajadores de Lima ignoran el espíritu de la producción y los trabajadores de San Martín se sienten incómodos por las presiones y exigencias de la sede de Lima. Los tres socios conscientes de ello vienen realizando algunas actividades espontáneas y reactivas de comunicación interna como: 
reuniones de integración, algunos viajes para que se conozcan, periódicos murales que se renuevan cada tres o cuatro meses y una revista para los colaboradores editada 3 veces al año.

Actualmente no hay un encargado de comunicación. Es el socio que vive en Lima, quién fomenta la comunicación entre los colaboradores y promueve las relaciones con las bioferias y los consumidores, es además quien recibe las llamadas WhatsApps de los pedidos.

Para los próximos 5 años, los socios fundadores desean incluir a nuevos acionistas y contratar a 100 colaboradores para la producción, administración y ventas de manera paulatina. Es preciso resaltar, que los nuevos accionistas no están convencidos de la inversión en comunicación (difusión, relacionamiento y diferenciación), considerando que la producción y distribución del producto es el mejor camino para alcanzar los objetivos.

\subsection{Público externo}

Hombres y mujeres entre los 21 y 35 años de NSE AB que residen en Lima.

Personas que tienen una preocupación por el cuidado del medioambiente y tener un estilo de vida saludable basado en un consumo responsable de productos.

Asisten a bioferias (Barranco, Miraflores, Surquillo, Pueblo Libre, Lince, La Molina, entre otros). 


\section{Arquetipo Mariana Del Valle}

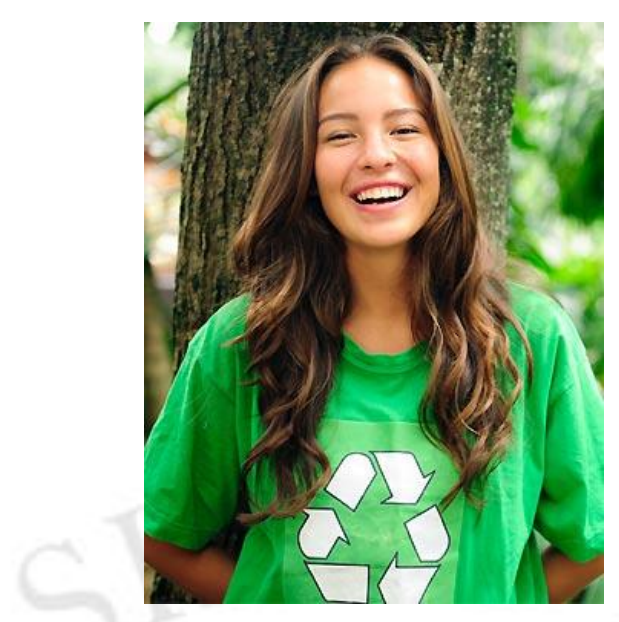

Mariana tiene 28 años y pertenece al NSE B, es dinámica, activa y reflexiva. Le gusta invertir tiempo en su imagen personal, buscando utilizar productos naturales en la mayoría de alimentos que consume y usa. Vive con su pareja Jorge de 31 años, en el distrito de Miraflores.

Dentro de sus aspiraciones está el poder coleccionar y compartir sus experiencias, dar a conocer su estilo de vida saludable, mantener su figura y salud y tener las capacidades económicas para poder comprar los productos que desee. En sus frustraciones, está el no alcanzar sus metas propuestas profesional y personalmente, sentir que su vida no va a dejar huella en su entorno, y la contaminación y falta de consciencia de algunas empresas que produce consecuencias negativas en el medioambiente.

Mariana es Analista de Marketing de una empresa peruana en crecimiento de productos para el cuidado personal, baño y el hogar. Se siente muy a gusto con su trabajo porque, además de definir, planificar y ejecutar estrategias para la venta de los productos en diversos canales y administrar la presencia de marca, comparte con sus compañeros de trabajo la conciencia por el cuidado del medioambiente, buscando comunicar la importancia de su aplicación en la organización.

En sus horarios de almuerzo en la oficina, Mariana prefiere comer de manera saludable, siempre buscando tener una porción de ensalada en su plato. Le gusta tomar jugos que prepara en su casa a base de cáscara de diversas frutas, infusiones y café orgánico.

Todos los fines de semana sale a caminar con su pareja, pasando siempre por la bioferia de Miraflores. Le gusta mucho este espacio porque se encuentra con personas que siguen su estilo de vida, así como una variedad de productos que compra para los primeros días de la semana. El que un producto sea orgánico, de calidad, llamativo en su diseño, pero no muy recargado y que contenga la información nutricional y de consumo o uso son atributos que Mariana considera muy importantes. También, dentro de su percepción, reconoce que en el Perú hay mucha riqueza y oportunidades de crecimiento emprendedor por lo que, cuando se da la oportunidad, busca apoyar a estos negocios y adquirir sus productos. Es importante recalcar que la calidad es muy importante para ella, por lo que la certificación de un producto es un aspecto que considera mucho. 
En cuanto a los puntos de venta de los productos, le gustaría encontrar los que compra en otros establecimientos, pues la biofería solo abre los fines de semana.

En el caso de sus pasatiempos, en algunas oportunidades realiza actividades de voluntariado enseñando talleres de reciclaje, además, le gusta la jardinería y manualidades para el hogar.

Por otro lado, de acuerdo a su conectividad en redes sociales, Mariana utiliza Facebook ocasionalmente para encontrar eventos ecoamigables a los que pueda asistir y ve videos cortos de temas de su interés. En el caso de Instagram, lo utiliza todos los días dándole "me gusta" a productos que le parecen innovadores, llamativos, imágenes de bienestar, deporte y ropa de emprendedores. Además, le da like a fotos de acontecimientos relacionados a campañas verdes, voluntariado y eventos. En cuanto a sus Instagram Stories, los utiliza para compartir los nuevos lugares saludables que visita, productos que consume personalmente y de la empresa en la que trabaja, así como las experiencias nuevas que pueda tener.

Cuando Mariana tiene una experiencia positiva con un producto, no duda en recomendarlo en el fanpage de la organización. En el caso de Instagram, le da "me gusta" a la página y al producto. Asimismo, le cuenta a sus conocidos y compañeros de trabajo sobre este y lo recomienda, enviándoles el enlace de la página web o red social que utiliza la empresa en caso ellos estén interesados.

En los medios de comunicación tradicionales, Mariana utiliza como primer diario El Comercio versión online, prefiriendo aquellas que apuesten por el bienestar de la sociedad en el ámbito educativo, ambiental, laboral, tecnológico, entre otros. También le parecen de utilidad las notas sobre tips o rutas para visitar o consumir que la plataforma coloca.

\subsection{Competencia}

De acuerdo a la venta de aceite de coco en el Perú se han elegido las siguientes empresas comercializadoras y puntos de venta con el objetivo de poder identificar las mejoras prácticas y aplicarlas hacia la filosofía corporativa de Coco Peruano.

- Peruvian Health

- Inkanat

- Veggispirit

- Organa

- Candela Perú

- Flora\&Fauna

Los indicadores comparativos a evaluar serán los siguientes. En el caso de la categoría "producto" se investigará específicamente sobre el aceite de coco.

1. Descripción de la empresa, filosofía

2. Servicios que ofrece

3. Imagen corporativa 
- El nombre de la empresa

- El logo y otros símbolos

- El eslogan

- Los colores (identidad cromática)

4. Producto

- Empaque

- Diseño

- Precio

- Distribución

5. Canales de comunicación

\section{- Peruvian Health}

\section{Descripción de la empresa}

Peruvian Health es una empresa dedicada a la comercialización del aceite de coco orgánico proveniente de Filipinas. Fue fundada en el año 2015 por tres familiares motivados por la necesidad mundial de consumir alimentos y productos saludables. Está posicionada como una empresa que desarrolla un catálogo de productos $100 \%$ naturales a base del aceite de coco.

Misión

Peruvian Health busca cambiar lo que consumimos a diario por opciones más sanas, desarrollando productos $100 \%$ naturales y beneficiosos para la salud de todos.

Visión

Llevar sus productos a la mayor cantidad de personas y así tener un impacto positivo en su salud. Posicionarse como una empresa de alto nivel en el sector de productos naturales.

2. Servicios que ofrece

Ofrece la venta de aceite de coco orgánico en diferentes presentaciones, así como diferentes productos elaborados en base a este como exfoliante corporal, crema corporal, bálsamos y kits de belleza. Además, ofrece utensilios realizados con coco como un bowl y una cucharita.

3. Imagen corporativa

- El nombre de la empresa: Peruvian Health

- El logo y otros símbolos 


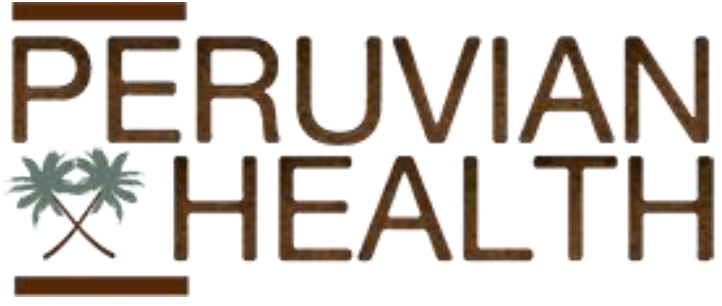

- El eslogan

¡Sé natural! es el insight de su marca y un mensaje que buscan que el consumidor aplique a lo que come, a lo que se pone en la piel, a lo que siente, piensa y es como ser humano.

- Los colores

Utilizan principalmente el color marrón en diferentes tonalidades, y el verde como color complementario. Estos colores provienen de la palmera. Asimismo, podemos apreciar el uso de textura en su logotipo

\section{Producto}

\section{Empaque}
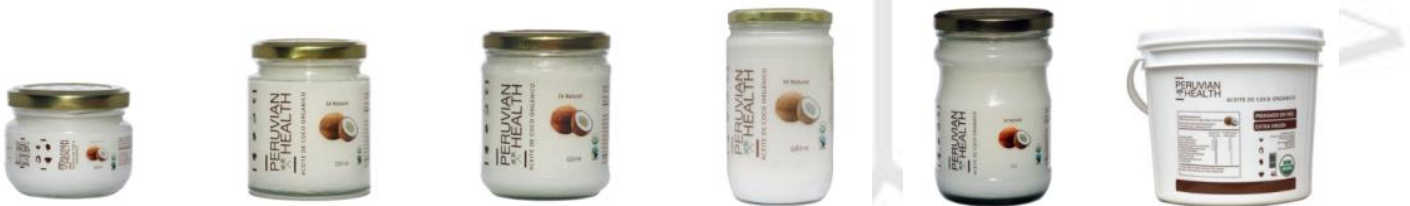

El aceite de coco orgánico virgen se presenta en pomos de vidrio con una tapa dorada. Viene en cuatro presentaciones de diferentes tamaños: $140 \mathrm{ml}, 250 \mathrm{ml}, 450 \mathrm{ml}, 680 \mathrm{ml}$, 11 y 41 .

\section{- Diseño}

La etiqueta tiene un fondo transparente que permite ver el producto. Contiene el logotipo de la empresa, una imagen del coco, las certificaciones que tiene el producto. Asimismo, encontramos el eslogan ¡Sé natural! y las especificaciones del producto.

\section{- Precio}

El precio del producto varía según el tamaño de este. La presentación de $140 \mathrm{ml}$ tiene un costo de $\mathrm{S} / 15$; la de $250 \mathrm{ml}, \mathrm{S} / 25$; la de $450 \mathrm{ml}, \mathrm{S} / 45$; la de $680 \mathrm{ml}, \mathrm{S} / 60$; la de 1 1, S/80; y la de $41, S / 240$. 
- Distribución

Se puede adquirir sus productos a través de su tienda online disponible en su página web, a pedido si se busca el producto a granel, o a través de su fanpage en Facebook donde venden sus productos derivados del aceite de coco.

Asimismo, se puede encontrar sus productos en la Ecoferia del Parque Mariscal Ramón Castilla y en Flora \& Fauna. Actualmente, han abierto una convocatoria a distribuidores independientes o empresas que quieran vender sus productos.

\section{Canales de comunicación}

A. Página web
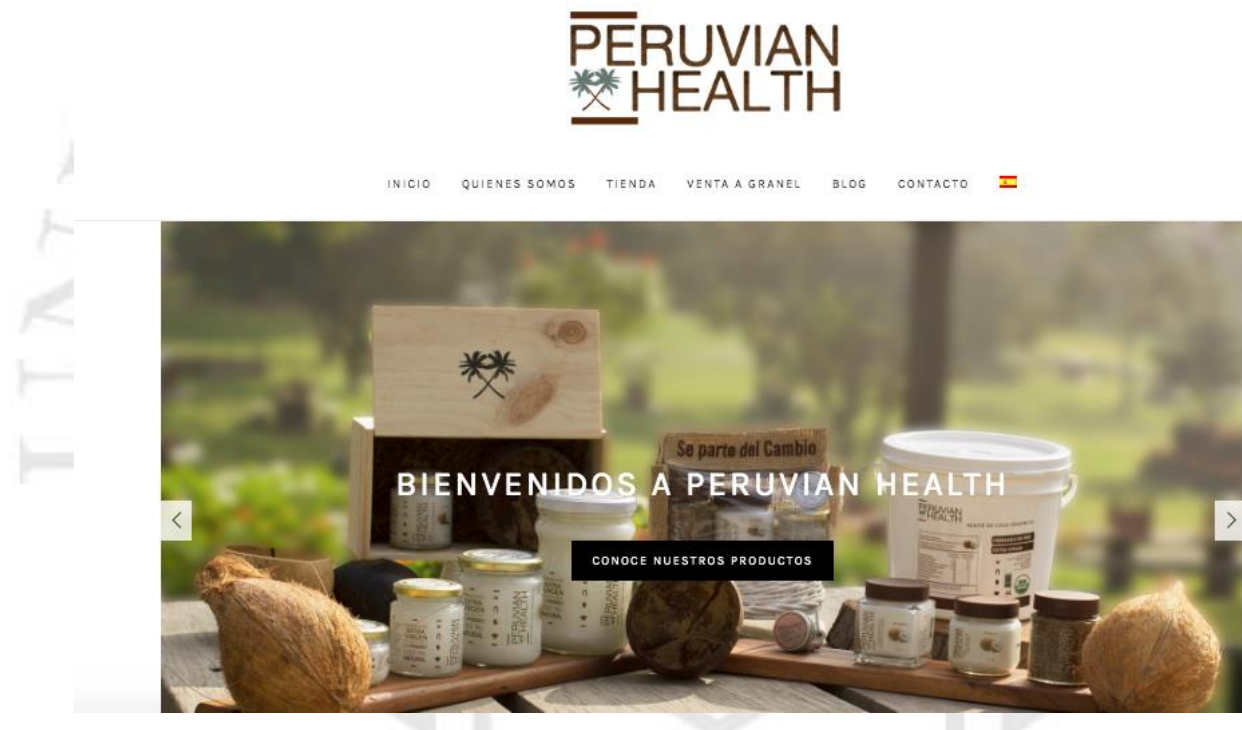

La página web de Peruvian Health posee los siguientes encabezados: Inicio, Quienes somos, Tienda, Venta a granel, Blog y Contacto. La página está dedicada a informar sobre sus productos basados en aceite de coco $100 \%$ orgánico y vírgen.

En la pestaña "Inicio" encontramos un slider con accesos directos a la página sobre los productos y a la tienda online. Utilizan imágenes propias de gran calidad donde presentan todos sus productos. Asimismo, encontramos tres imágenes de los principales productos que te llevan a su página informativa individual. Luego, encontramos un video donde una health coach y fitness trainer hace una presentación de los productos. Más abajo tiene un banner donde muestran las características principales de su producto. Finalmente tenemos una visualización de sus publicaciones en Instagram y el footer.

En la pestaña "Quienes somos" se encuentra la descripción de la empresa, su historia, su misión y su visión. Además, presentan indicadores como el número de unidades vendidas $(3,814)$ y la cantidad en seguidores que tienene en Facebook (20k).

En la pestaña "Tienda", se presenta el catálogo de productos que tienen. Puedes agregar directamente al carrito o hacer click a la foto del producto para ver información detallada 
de este. Cabe resaltar que en esta página informativa de detalle se puede agregar comentarios sobre el producto, lo cual suma al atractivo de este.

En "Venta a granel", se encuentra la información sobre el proceso para solicitar el producto en esa presentación, así como un formulario de solicitud y envío de información.

En la pestaña "Blog" se publican notas, artículos y recetas preparadas con aceite de coco. El CEO de la empresa escribe artículos en esta sección. Están permitidos los comentarios, que son respondidos oportunamente por un representante de la empresa.

Finalmente, en la pestaña “Contacto" se encuentra un formulario de contacto y teléfonos.

En el header encontramos los botones para crear/acceder a tu cuenta, así como el carrito de compras.

La página es clara en la presentación y orden de la información. Visualmente es sencilla de leer y los colores, fotografías y animaciones que utiliza le dan vida.

\section{B. Facebook}

El nombre de su fanpage en Facebook es Aceite de Coco Peruvian Health. Esta elección de nombre es conveniente pues habla directamente del producto, lo cual no quedaría claro si solo colocasen Peruvian Health.

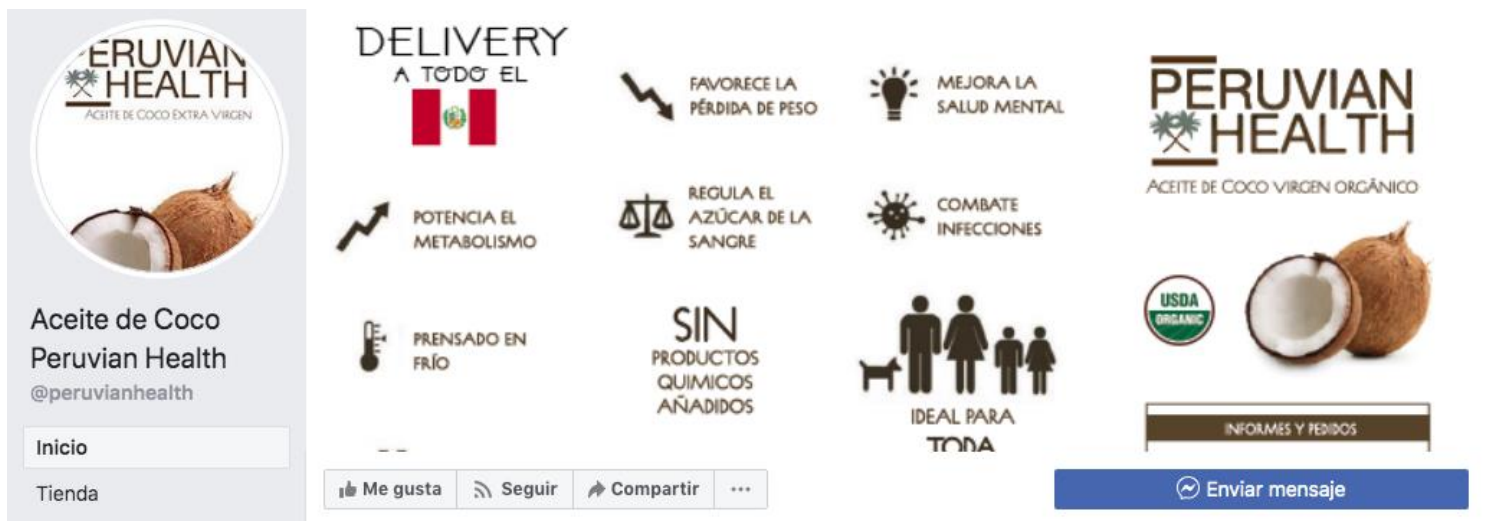

La página cuenta con 23,459 seguidores. Se refieren a sus seguidores como "cocolovers". Tienen diferentes tipos de publicaciones donde siempre se destaca la imagen del producto: fotos del producto, anuncios de participación en ecoferias, modelos utilizando el producto, diversos anuncios organizacionales (certificaciones, voluntariado, entrevistas en medios, nuevos locales distribuidores), recetas, tips de uso del producto, entre otros. En ocasiones ha publicado memes que son populares en el momento, relacionándolos con su empresa.

En todas sus publicaciones, utilizan los hastags \#SeNatural y \#SeParteDelCambio, los cuales comunican la misión de la empresa. 
B. Instagram

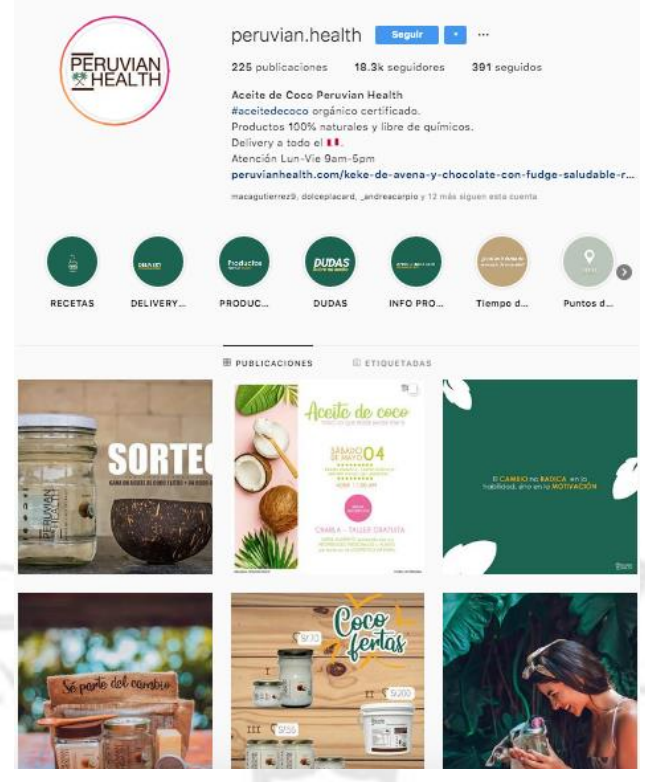

Peruvian Health tiene una cuenta en Instagram con el mismo nombre de la empresa. Tiene $18.3 \mathrm{k}$ seguidores y ha realizado 225 publicaciones, las cuales en su mayoría son rebotes de sus publicaciones en Facebook.

\section{- Inkanat}

1. Descripción de la empresa

Inkanat se crea en España en el año 2006, luego en el 2008 se crea Inkanat Perú como una central de compras para la empresa española. Inkanat se identifica como una empresa joven, dinámica y multicultural consciente de la mega diversidad y riqueza del patrimonio alimenticio de la región andino-amazónica. Posee la mejor materia prima y productos de alto valor agregado obtenidos con estrategias de desarrollo sostenible (económico, social y ambiental).

Filsofía

Inkanat postula los siguientes enunciados:

- La naturaleza es una gran fuente de conocimiento aún no muy bien conocida ni difundida.

- Todos los pueblos y culturas del mundo poseen una enorme riqueza de conocimiento sobre el entorno de que los rodea, fruto de muchas generaciones de aprendizaje.

- Nuestra sociedad occidental esta fascinada con la tecnología y la vida moderna que ha dejado de lado el saber universal, atemporal de la naturaleza.

- El comercio justo y la igualdad de oportunidades entre los pueblos pasa por aceptar el conocimiento y los productos de todos los pueblos por igual.

- La puesta en valor del conocimiento tradicional nos permite desarrollar y ofrecer los mejores productos que actualmente son comercializados en diferentes mercados alrededor del mundo conjuntamente con nuestra sede en España. 
- Nuestro trabajo tiene como objetivo final que más personas puedan acceder a los mejores productos de esta región sudamericana para el cuidado de su salud, belleza y bienestar personal.

- Trabajo responsable con comunidades andinas, calidad en productos orgánicos, variedad en materia prima.

2. Servicios que ofrece

- Importación y Exportación de materias primas y productos terminados de Sudamérica.

- Desarrollo y comercialización de complementos alimenticios, alimentación y cosmética natural.

- Venta al por mayor de productos terminados y de materias primas.

- Venta a comercios especializados.

- Venta por Internet.

3. Imagen corporativa

- El nombre de la empresa: Inkanat

- El logo y otros símbolos

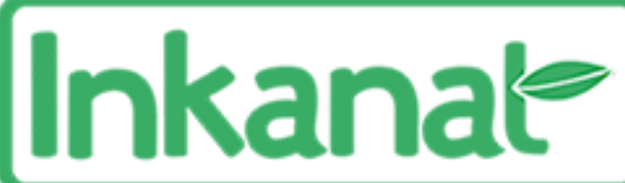

- El eslogan

Del trabajo responsable con comunidades nativas se obtiene un producto de alta calidad

- Los colores (identidad cromática)

El color principal utilizado es el verde en diversas tonalidades, seguido por el blanco, naranja y gris. Se puede inferir que el primer color puede estar vinculado con el concepto de naturaleza, productos orgánicos

4. Producto

- Empaque

El producto se presenta en una versión de $150 \mathrm{ml}$ y $400 \mathrm{ml}$, en un envase transparente circular. 
El diseño de la etiqueta cuenta con una figura de la fruta de donde proviene el aceite, acompañado del logo y las características del producto. El fondo es blanco con dos delgadas líneas marrones en la parte superior e inferior de la etiqueta.

- Precio

El precio del producto se encuentra entre 25 soles $(150 \mathrm{ml})$ y 45 soles $(400 \mathrm{ml})$.

- Distribución

El producto puede ser encontrado en la tienda online de Inkanat, tiendas orgánicas y naturales en Lima y pronvicia y centros de Yoga.

5. Canales de Comunicación

A. Página web

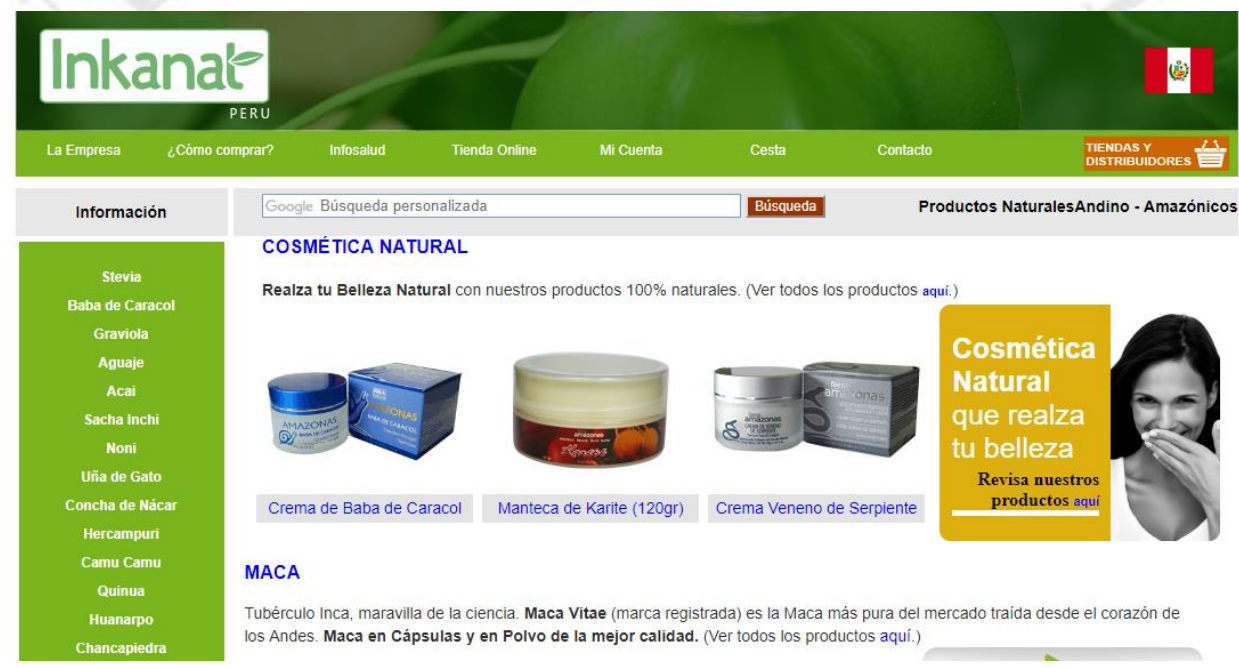

La página web de Inkanat posee los siguientes encabezados: La empresa, ¿Cómo comprar?, Infosalud, Tienda online, Mi Cuenta y Contacto. A primera vista, se puede identificar que es una página de venta de productos orgánicos variados.

En la pestaña "La Empresa" se muestra las opciones Quienes Somos y Filosofía, además de las actividades que realizan y un enlace hacia la página sobre la organización inkanat y su labor con comunidades, proyectos y el entorno natural.

En la pestaña “¿Cómo comprar?”, se presenta el proceso de compra descrito y los números de cuenta.

En "Infosalud", se encuentran diversos artículos sobre las descripciones y beneficios de los productos que vende Inkanat.

En la "Tienda online", se muestran todos los productos acompañados de la información y una imagen del mismo.

En la pestaña "Mi cuenta", el consumidor que desee adquirir los productos debe colocar su información y loguearse para acceder a los servicios de la organización. 
Finalmente, en la pestaña "Contacto" se encuentra un formulario de contacto y teléfonos.

Al lado derecho de las pestañas mencionadas, se presenta un botón llamado Tiendas y Distribuidores que lleva a otra página web donde se encuentra la información de los puntos donde se pueden encontrar los productos.

En el caso de la usabilidad, es fácil navegar por el sitio; nos obstante, la información podría encontrarse mejor presentada. La web cuenta con dos columnas a los costados donde se aprecian gran diversidad de datos, ello puede generar contaminación visual y la sensación de estrechez. La información dentro de casa pestaña es clara y se reconocen los productos que vende Inkanat de manera sencilla.

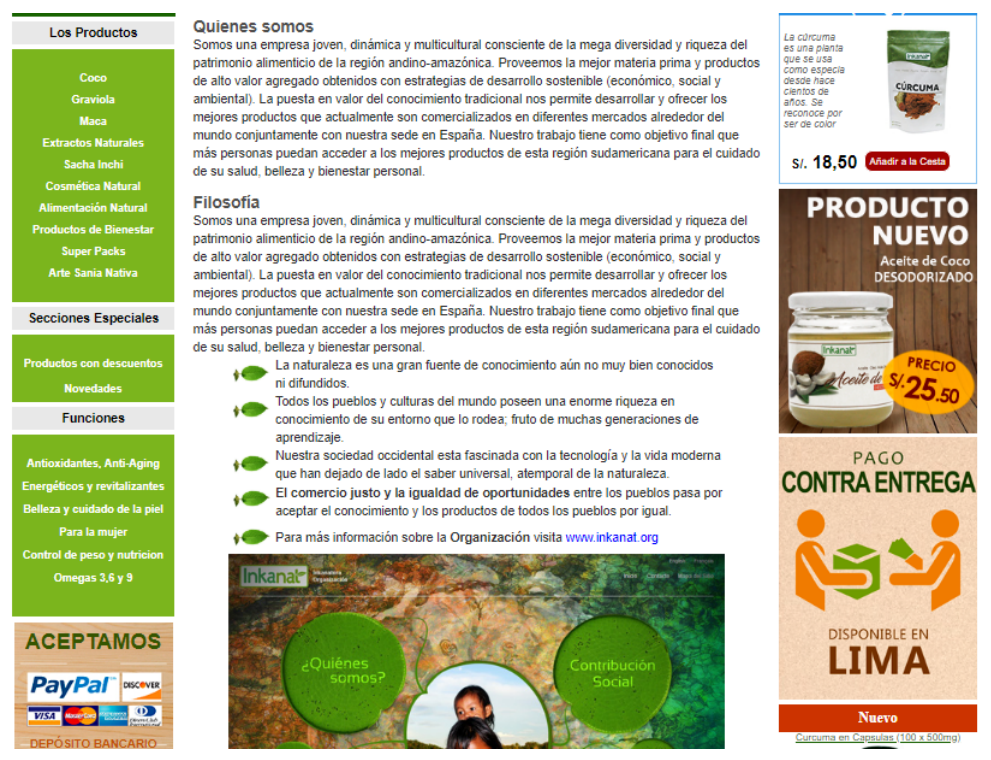

B. Facebook

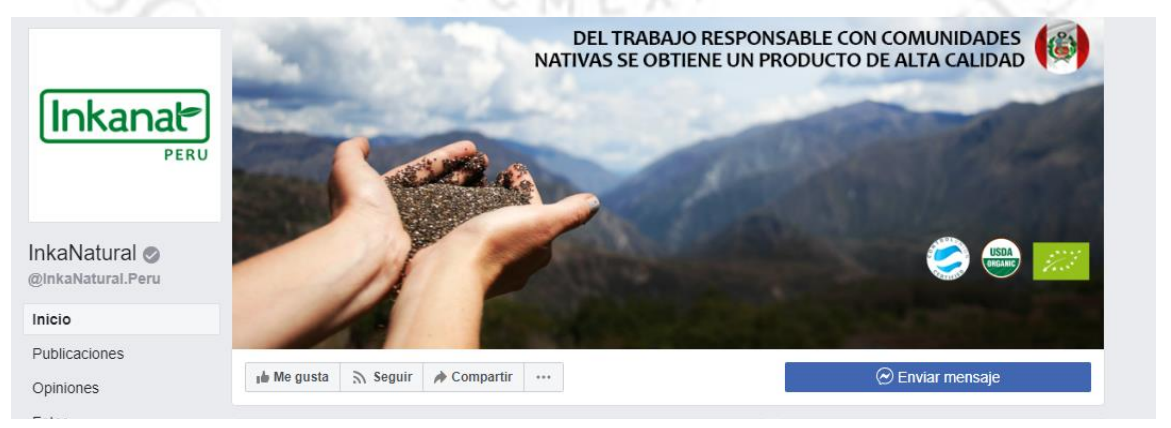

El fanpage de Inkanat cuenta con 9,000 seguidores. Sus publicaciones son diversas y llenas de color. Utilizan las imágenes de sus productos para promocionarlos, así como recuadros de texto donde comunican los beneficios y características de los mismos. Principalmente, los post que realizan son informativos y enfocados a la venta de sus productos, además cuentan con otros enfocados a comunicar sus locales de distribución, saludos por fechas festivas, entre otros. 


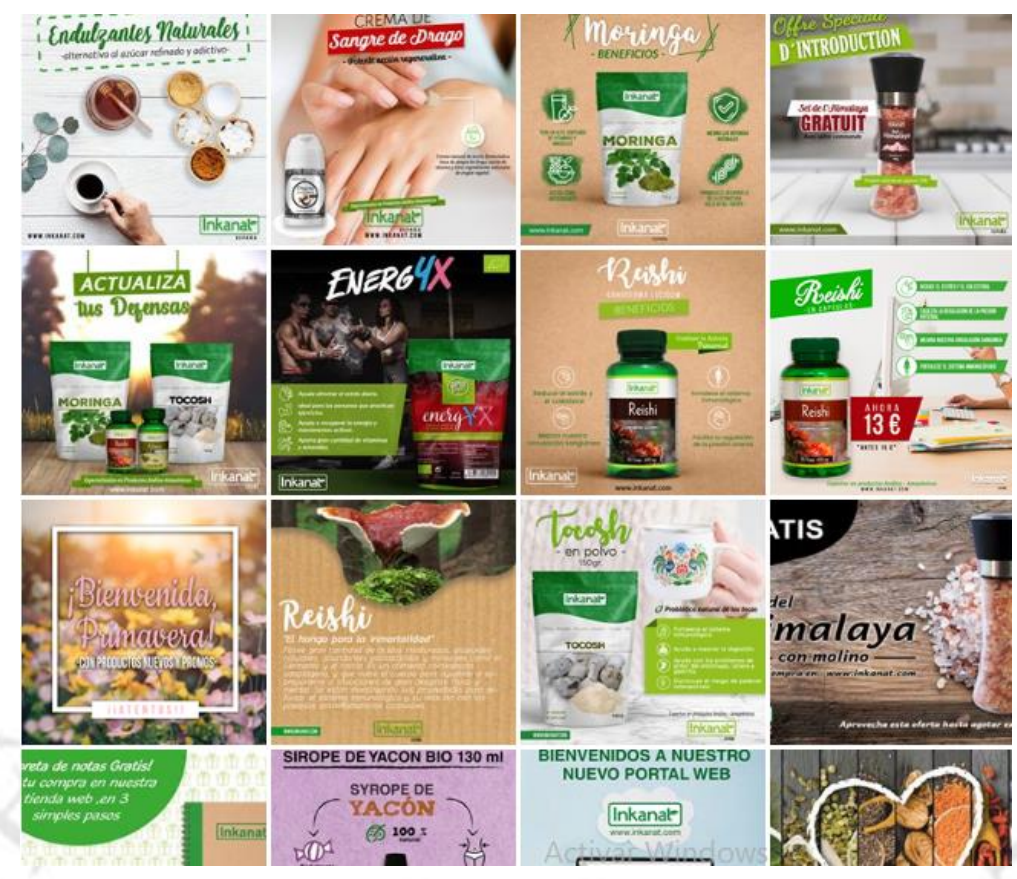

En cuanto a sus copys, comunican los beneficios del producto que están vendiendo, recomendando además otros productos que puedan tener características similares. Además, acompañan sus publicaciones con los datos de información, así como hashtags como \#Inkanat \#InkanatProductos \#InkanatOrgánico \#ProductosOrgánicos

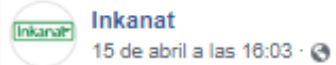

\#Inkanat \#InkanatProductos \#InkanatCosméticos \#InkanatOrgánico \#ProductosOrgánicos \#ProductosNaturales \#Plantbased

Para más infoe

(8) Lun a Jue: $9 \mathrm{am}-6 \mathrm{pm} /$ Vier: $9 \mathrm{am}-3 \mathrm{pm}$

E (0034) 943467089

* info@inkanat.com

Eww.inkanat.com 


\section{Youtube}

En su canal Inkanat Oficial, cuentan con algunos videos sobre la presentación de Inkanat, su relación con las comunidades y videos sobre ciertos productos como la Chía, Aguaje, Muña, entre otros. El canal no cuenta con movimiento actualmente.

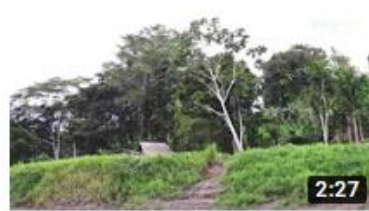

EI DESEO de HAMILTON Apu de la Comunidad Sargento... 110 vistas . Hace 5 años

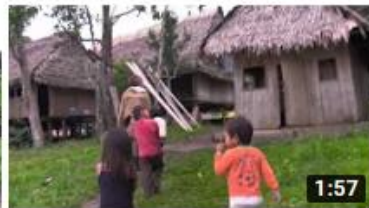

UNA MIRADA A LA SELVA

135 vistas . Hace 5 años

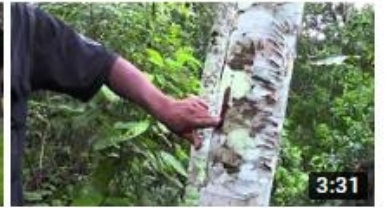

INKANAT PERÜ |

TRABAJANDO CON LAS...

76 vistas $\cdot$ Hace 5 años

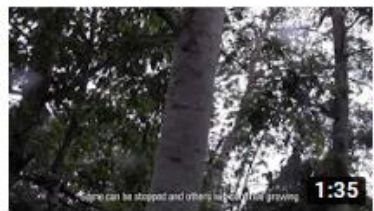

INKANAT PERU | SANGRE DE GRADO

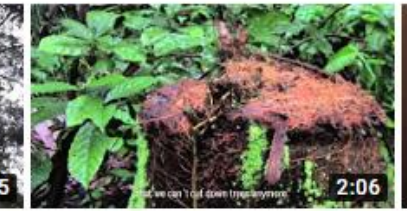

INKANAT PERÜ | AGUAJE

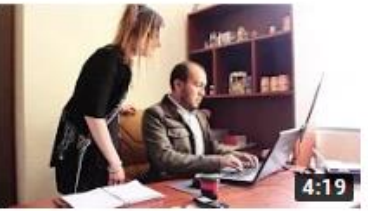

COMEXPERU ENTREVISTA INKANAT COMO CASO DE...

Por otro lado, Inkanat cuenta con menciones en los diarios online "Correo" en el 2018 sobre medicina alternativa y "Opinión Bolivia" en el 2016 sobre productos para subir las defensas. Además, de un video en el 2017 como exportador de la semana en la Asociación de Exportadores ADEX.

\section{- Veggispirit}

\section{Descripción de la empresa, filosofía}

Veggispirit inicia sus ventas en el 2005 en Granada España, con más de 700 productos orgánicos, la demanda de un público exigente y la concepción de la alimentación sana como tendencia principal. Luego continúa el negocio aperturando una sede en el Perú con productos de uso indispensable que conservaran sus características biológicas en beneficio de la salud de los consumidores.

En el año 2012 crearon Cocus, aceite de coco extra virgen, prensando al frío. Veggispirit menciona que su calidad, aroma y consistencia lo hace diferente a todas las marcas que aparecieron después. Tambien cuenta con Cocus Virgen, 100\% coco deshidratado, de alta calidad a un menor precio, para uso en gastronomía y repostería.

\section{Misión:}

Investigar las propiedades de los productos naturales para incorporarlos en nuestra dieta de manera que nos mantengan siempre sanos y nos permita utilizarlos a su vez en el alivio de múltiples dolencias.

Difundir los beneficios de una dieta natural, pues es la información la que nos otorga, la posibilidad de elegir correctamente como alimentarnos. 
Visión:

Convertirnos en la ventana a través de la cual los productos originarios del Perú puedan ser adquiridos por el mundo. Cada uno de ellos ha sido escogido de manera específica por sus propiedades y beneficios nutricionales, los cuales están garantizados en calidad y sanidad.

2. Servicios que ofrece

Venta de productos con certificación orgánica como el aceite de coco, cúrcuma medicial y sal de maras al exterior, al por mayor y en puntos de venta en Lima y Provincia.

3. Imagen corporativa

- El nombre de la empresa: Veggispirit

- El logo y otros símbolos

- El eslogan

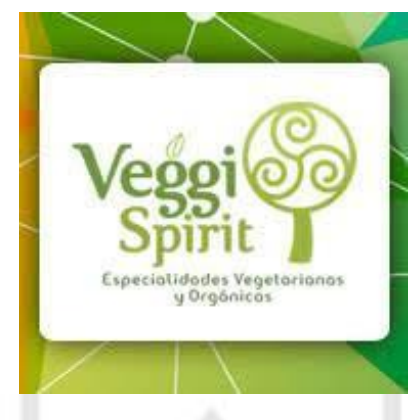

Especialidades Vegetarianas y Orgánicas. En el caso del producto Cocus el eslogan es Un aceite que te mantiene sano, tonificado y nutrido.

- Los colores (identidad cromática)

Veggispirit cuenta con una variedad de colores en su presentación en tonalidades pasteles. Los diversos colores que utilizan hace referencia a la bandera del tahuantinsuyo. Este vínculo se da ya que es en la provincia de Cusco donde trabajan con pequeños productores y obtienen sus productos.

4. Producto

- Empaque

El producto cuenta con presentaciones de 100gr, 250gr, 450gr y $1 \mathrm{~kg}$ diferenciados entre el Extra Virgen Pensado al frio y Cocus Virgen.

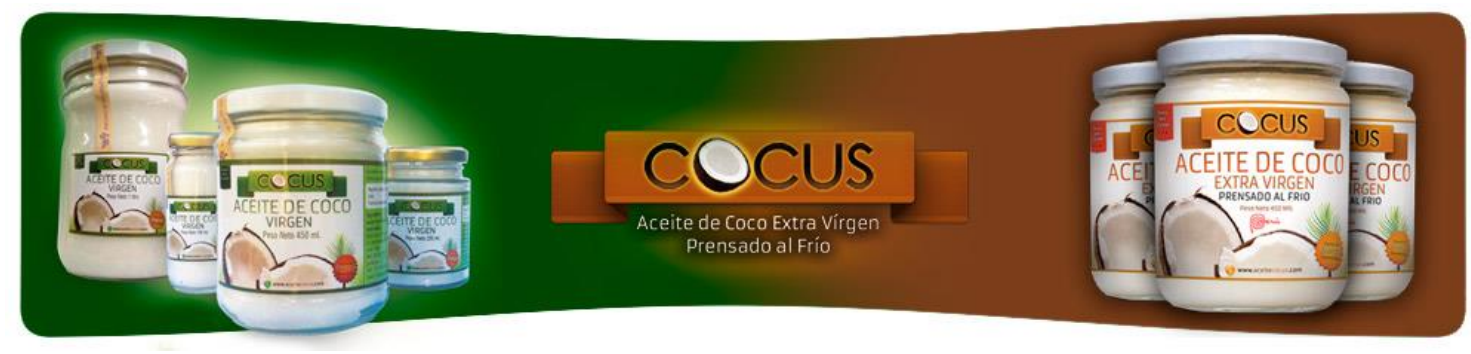


Ambos productos muestran la imagen de la fruta, acompañada del logo "Cocus" que se encuentra dentro de un banderín en tonalidades marrones. Además, se presenta el nombre del producto, tipo, presentación y la dirección de la página web con una tipografía llamativa, legible utilizando los colores de la fruta y el logo. El fondo del diseño es de color blanco, utilizando dos delgadas líneas en la parte superior e inferior de la etiqueta que rodean todo el envase. Además, se reconoce un sello narnaja en la parte fontal inferior de la etiqueta donde resalta la palabra "energía".

En la parte posterior de la etiqueta se encuentra un recuadro en color mostaza con la información del producto.

- Precio

El precio del producto se encuentra entre 23 soles (100gr.) 33 soles (250gr), 53 soles (450gr.), 100 soles $(1 \mathrm{~kg})$.

\section{- Distribución}

El producto puede ser ubicado en diversas tiendas naturales y ecológicas en Lima y otras provincias como Cusco, Arequipa, Puno, entre otras. Además, el producto se puede encontrar en Bolivia y Chile.

5. Canales de comunicación

A. Página web

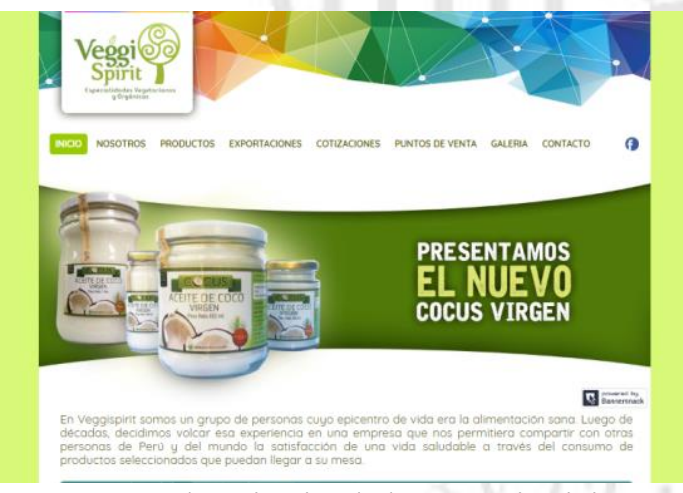

Imagen web principal de Veggispirit.

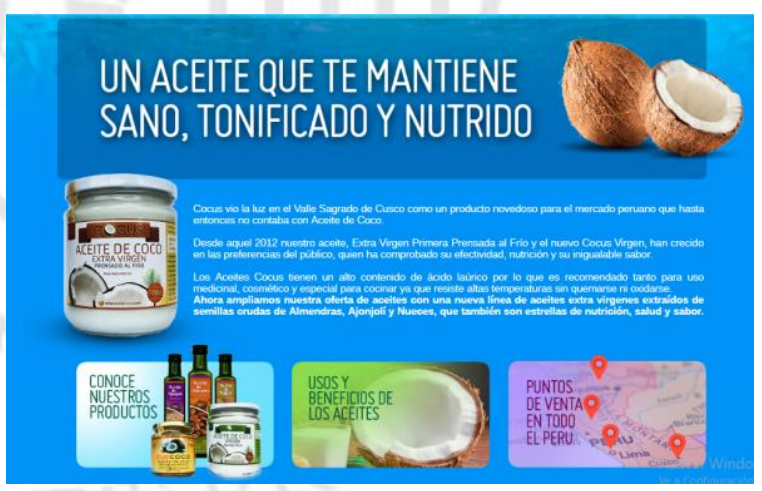

Imagen web del aceite de coco "Cocus".

En el caso de la página web se puede identificar que la marca cuenta con una página donde comunica sobre sus productos en general y 3 páginas más específicas a los productos de aceite de coco, cúrcuma y sal de maras.

La página web principal posee los siguientes encabezados: Inicio, Nosotros, Productos, Exportaciones, Cotizaciones, Puntos de Venta, Galeria, Contacto.

En la pestaña "Inicio" se puede encontrar un slider con las imágenes de los productos, seguido por una descripción de la empresa y las certificaciones orgánicas con las que cuentan. 
En "Nosotros", Veggispirit cuenta su historia, misión y visión, así la responsabilidad social de la organización.

En "Productos", se muestra el aceite de coco, la curcuma medicina y la sal de maras. Cada uno cuenta con un vínculo dentro de la página donde se describe el producto, beneficios, historia y aplicación. Asimismo, se presentan botones para tener la posibilidad de comprar los productos, hacer cotizaciones y ver los puntos de venta.

En las pestañas "Exportaciones", "Cotizaciones" y "Puntos de venta" se encuentran fichas de datos de acuerdo a lo que el cliente está buscando

En “Galería”, se muestran fotografías de los tres productos de Veggispirit.

Finalmente, en "Contacto", se ubica la dirección y correo de la empresa, así como un formulario.

Al lado derecho de las pestañas mencionadas, se puede encontrar el botón al fanpage de la empresa

En el caso de la usabilidad, es fácil navegar por el sitio; nos obstante, a pesar de que la información es clara, relevante y educativa, podría comunicarse de una manera más dinámica y atractiva.

La página web del producto Cocus posee los siguientes encabezados: Inicio, Nuestros Productos, Usos y Beneficios, Quienes somos, Dónde Comprarlos, Cocus Ads y Contáctanos

En la pestaña "Inicio", se encuentra la descripción del producto, así como botones para conocer los demás productos que vende la empresa, usos y beneficios del aciete y los puntos de venta en el Perú.

En la pestaña "Nuestros Productos", se presenta el aceite de coco y las variedades en las que se ofrece, así como aceites con otros componentes.

En "Usos y Beneficios", se muestra la información del aceite de coco y características del producto.

En "Quiénes Somos", se encuentra la historia de Veggispirit, así como los enlaces de la web y de los demás productos de la organización.

En la pestaña "Dónde comprar", se presentan las direcciones y horarios de atención de las tiendas donde Veggispirit vende sus productos.

En la pestaña "Cocus Ads", se muestran dos videos donde se comunica el proceso del aceite de coco, sus características e información sobre otros productos.

Finalmente, en "Contacto", se ubica la dirección y correo de la empresa, así como un formulario.

Al lado derecho de las pestañas mencionadas, se puede encontrar el botón al fanpage del aceite de coco "Aceite Cocus". 
En el caso de la usabilidad, es fácil navegar por el sitio. La información sobre el producto es completa, relevante y está acompañada de elementos visuales.

\section{B. Facebook}
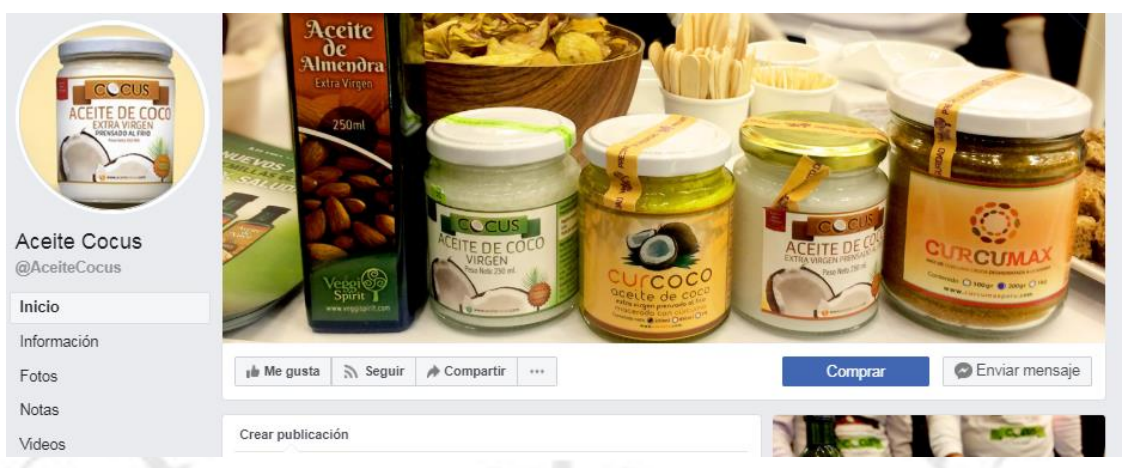

El fanpage de Aceite Cocus cuenta con 2,400 seguidores. Sus publicaciones comunican los beneficios del producto de manera creativa, ferias donde participan y degustaciones. La aplicación de colores es diversa, no guarda una línea gráfica muy clara. Utilizan las imágenes de sus productos en los post.

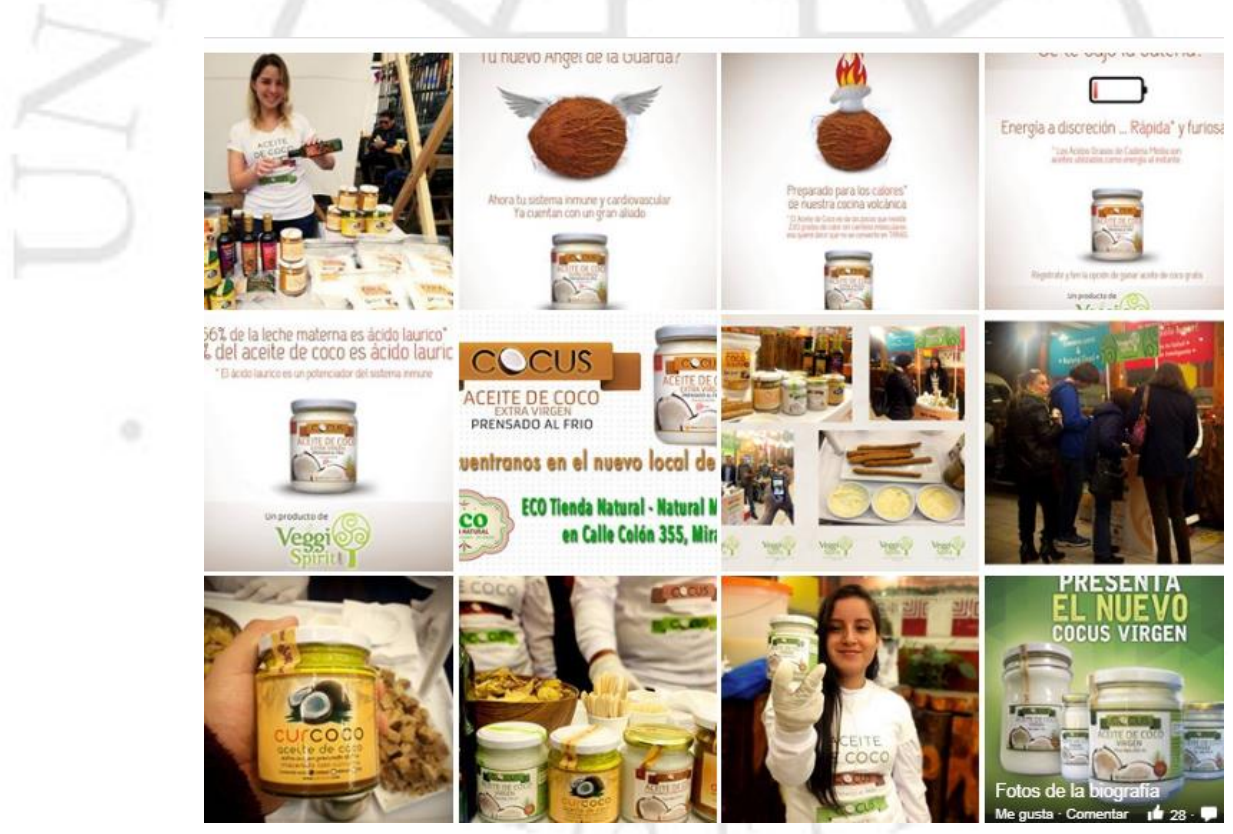

En cuanto a sus copys, comunican los beneficios del producto que están vendiendo, colocando en la mayoría de sus publicaciones el enlace que redirige a los puntos de venta. Además, acompañan sus publicaciones con hashtags como \#vivenatural, \#aceitecocus, \#aceitedecocoperú 
más.

6 de agosto de $2018 \cdot \theta$

Ya sabes que el aceite de coco es ugran aliado de tu sistema inmune y cardiovascular. No compres imitaciones. Puedes ubicarnos en los siguientes puntos de venta: http://aceitecocus.net/donde-comprarlos/4594365458

\#aceitedecoco \#aceitedecocoperu \#aceitecocus \#aceitecocusextravirgen

C. Instagram

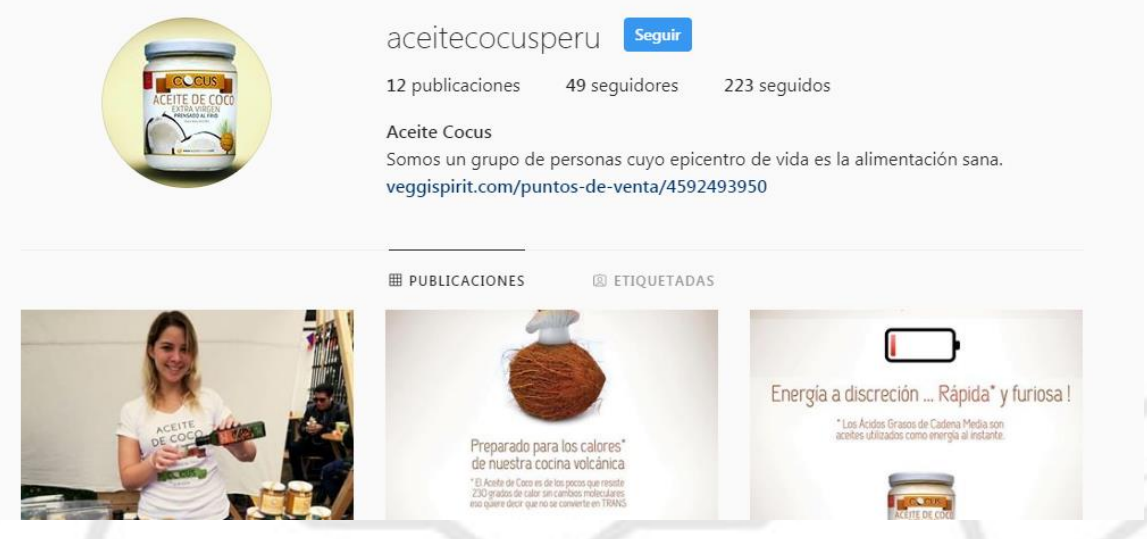

Veggispirit tiene un perfil en Instagram donde comunica sobre el aceite de coco "Cocus". Cuenta con 49 seguidores. Ha realizado 12 publicaciones utilizando las mismas piezas de Facebook.

\section{- Organa}

1. Descripción de la empresa, filosofía

Organa es una cadena de tiendas de productos saludables. Abre su primera tienda en mayo del 2018 en el distrito de Magdalena

Apuesta por un formato de supermercado en el layout del local, es decir con góndolas y pasillos central y laterales que permitan al cliente vivir una experiencia dinámica de compra.

\section{Servicios que ofrece}

Venta de productos orgánicos comestibles, de cuidado personal y para mascotas. 


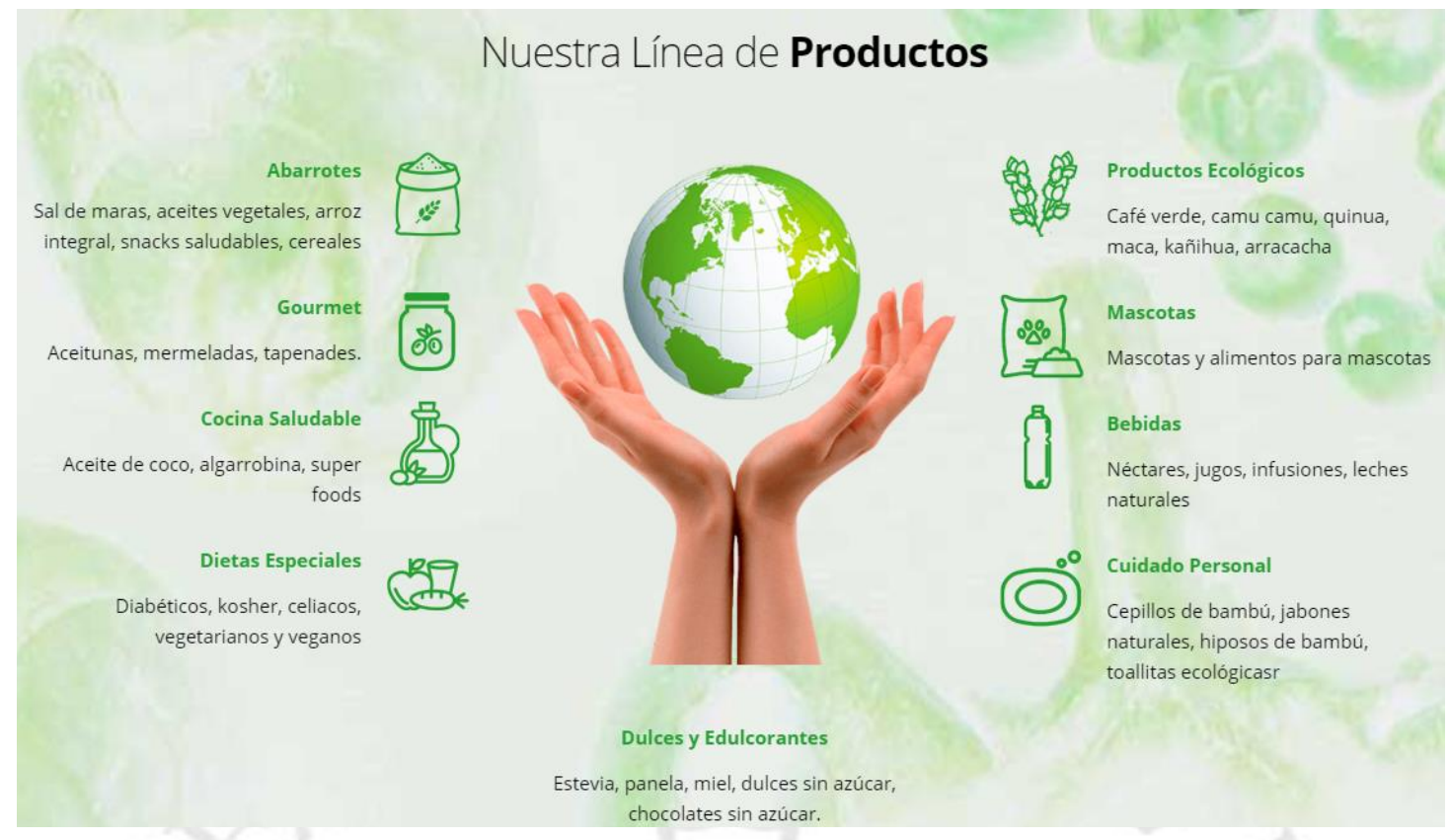

3. Imagen corporativa

- El nombre de la empresa: Organa

- El logo y otros símbolos

\section{Organa \\ Tienda orgánica y nutritiva}

- El eslogan

Los productos de Organa por su calidad hacen posible: cuidar tu salud, tener gran vigor y óptima nutrición.

- Los colores (identidad cromática)

Organa utiliza como color central el verde, seguido por blanco y el negro en menores cantidades. El color verde hace referencia a lo orgánico y nutritivo que caracteriza su tienda.

\section{Producto \\ - Empaque}

El producto que comercializa Organa es el aceite de coco orgánico de la marca Peruvian Health. Cuenta con presentaciones de $11 \mathrm{t}, 250 \mathrm{ml}, 200 \mathrm{ml}$ y $140 \mathrm{mil}$. 


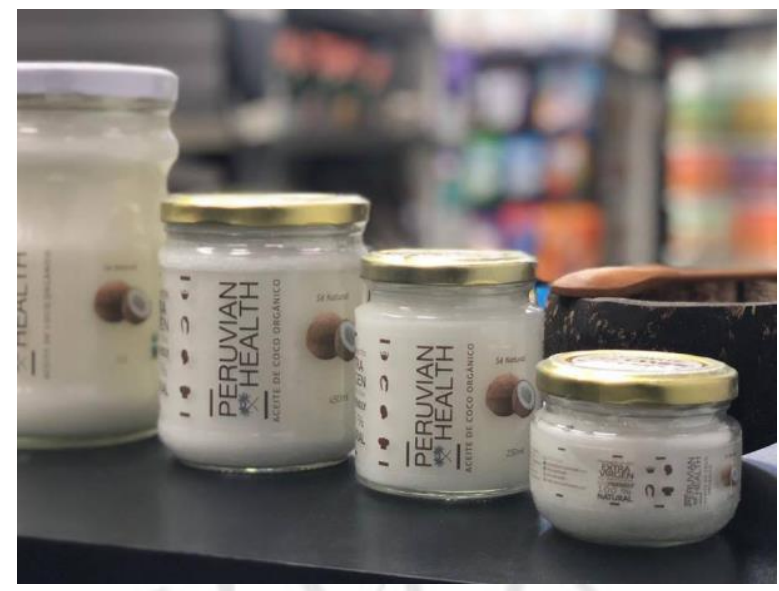

- Diseño

El diseño del producto Peruvian Health se encuentra alineado a la identidad gráfica de Organa que se muestra, además de orgánica, moderna, llamativa y minimalista. El desarrollo del diseño de Peruvian Health se ha realizado en líneas anteriores.

- Precio y Distribución

El precio y distribución del producto Peruvian Health se ha realizado en líneas anteriores.

5. Canales de comunicación

A. Página web

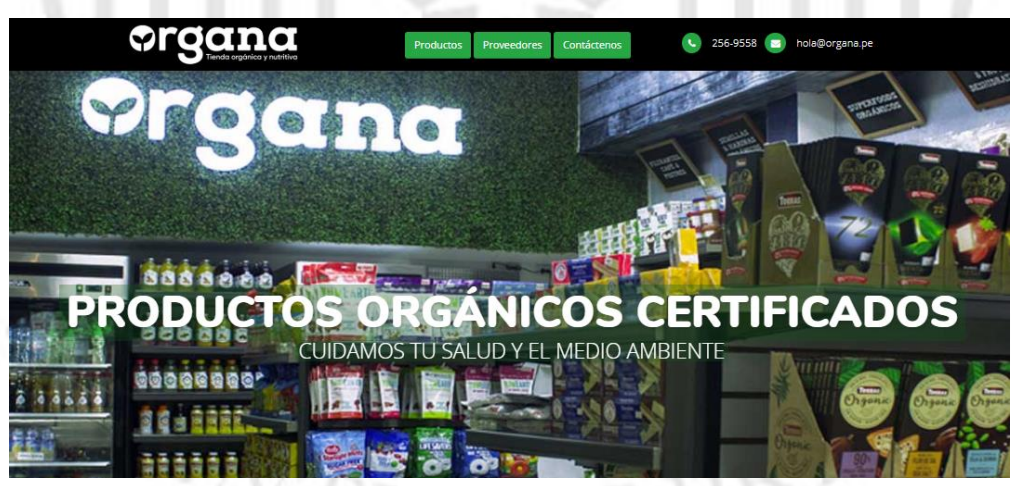

Organa posee una web de una sola página con los siguientes encabezados: Productos, Proveedores, Contáctenos.

En la sección "Productos", se pueden encontrar las cualidades y las diversas líneas que vende la empresa.

En "Proveedores", se muestra un slider con los proveedores con los que cuenta Organa.

Finalmente, en la sección "Contáctenos", se presenta la descripción de la empresa, información de contacto, un formulario y botones que linkean a su fanpge e Instagram.

En el caso de la usabilidad, es fácil navegar por el sitio; nos obstante, la organización podría desarollar más la web brindando más contenido sobre sus productos, cultura, etc. 


\section{B. Facebook}

El fanpage de Aceite Cocus cuenta con 7,100 seguidores. Sus publicaciones comunican principalmente los productos que venden, utilizando imágenes de los mismos como foco central. Además, realizan post esporádicos donde invitan a nuevas marcas a unirse a Organa.

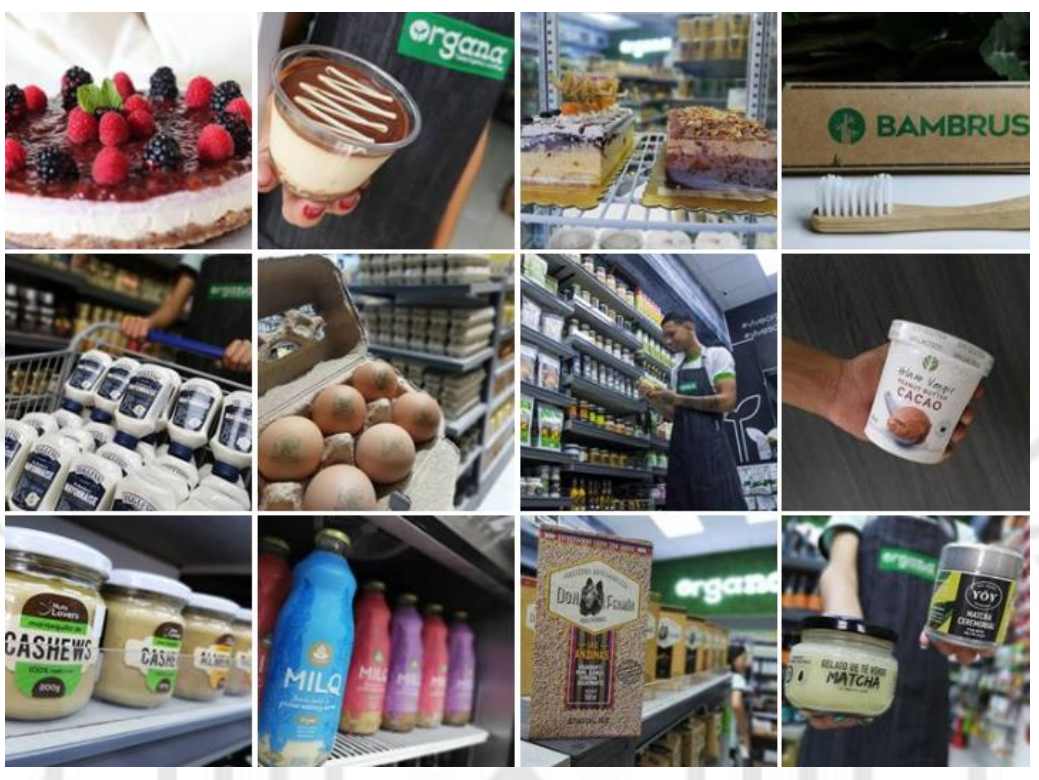

Los colores utilizados vienen de las fotografías de sus productos. Para la composición, utilizan encuadres cerrados lo que permite apreciar bien el producto, enfocando el mismo y desenfocando el fondo.

En cuanto a sus copys, comunican los productos con los que cuentan invitando a su consumo. Además, acompañan sus publicaciones con hashtags diversos dependiendo del producto.

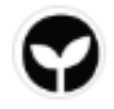

\section{Organa - Tienda orgánica y nutritiva}

11 de abril a las 19:44 - 6

\section{HUMMUS + PITA CHIPS 0 \\ Placer Absoluto !}

Ya están disponibles en Organa প.

\#pitachips \#hummus \#healthyfood \#saludable \#piqueo \#organaperu 
C. Instagram

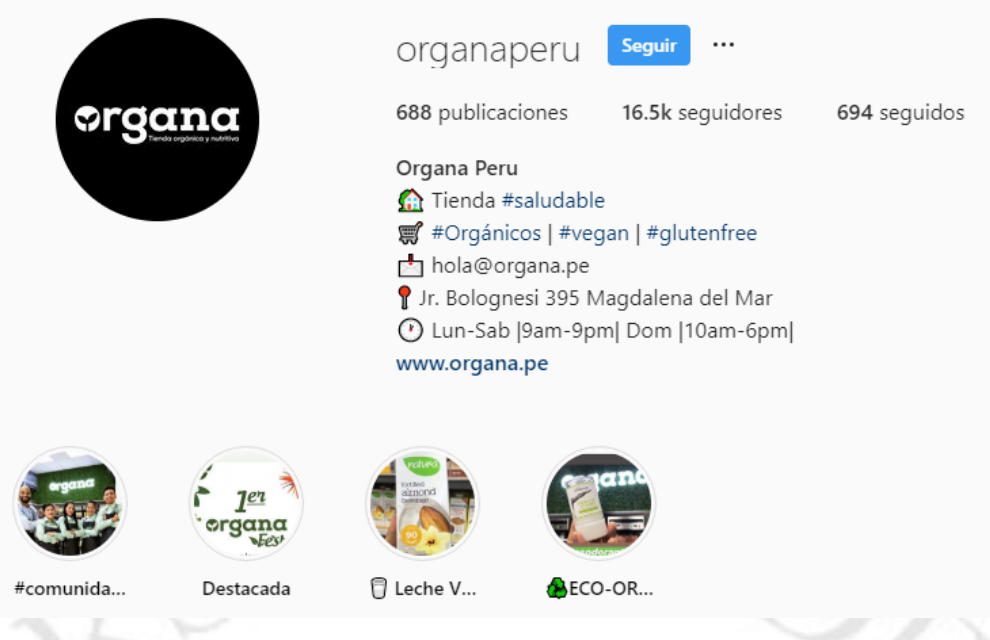

Organa tiene un perfil en Instagram con $16.5 \mathrm{k}$ de seguidores. Ha realizado 688 publicaciones utilizando las mismas piezas de Facebook. La empresa aplica los Instagram Stories, actualmente cuenta con cuatro fijados con los hashtags \#comunidadorgana, \#Destacada, \#Eco-Organa y \#LecheVegetal.

Asimismo, utiliza IGTV para mostrar sus productos, degustaciones y mensajes del nutricionista de Organa.

\section{- Candela Perú}

1. Descripción de la empresa

Candela Perú es una empresa peruana dedicada a la transformación y comercialización de productos orgánicos, contribuyendo al desarrollo y fortalecimiento de cadenas de valor basadas en la biodiversidad peruana. Fue fundada en 1989 y actualmente cuenta con dos plantas de procesamiento, en Lima y Madre de Dios.

Misión:

Candela es una organización líder en el desarrollo de mercados éticos de productos orgánicos de calidad con énfasis en el fortalecimiento de las cadenas de valor amazónicas y andinas a través del empoderamiento de las capacidades de los productores rurales, haciendo uso sostenible de los ecosistemas de donde provienen.

\section{Servicios que ofrece}

Candela Perú trabaja con productores individuales, asociaciones, micro y pequeñas empresas de diferentes zonas del Perú para ofrecer dos tipos de productos orgánicos: venta de productos a granel y productos a detalles entre los que se encuentran los aceites comestibles como el aceite de coco.

\section{Imagen corporativa}


- El nombre de la empresa

El nombre CANDELA PERÚ corresponde a las siglas de Comercio Alternativo de Productos No Trdicionales y Desarrollo para Latino América Perú.

- El logo y otros símbolos

\section{CANDELA}

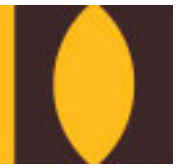

- El eslogan

El eslogan de Candela Perú es "Hacerlo bien, hacer el bien", el cual hace referencia al proceso con el que obtienen sus productos orgánicos, así como el impacto que tiene su trabajo en las comunidades que participan en la producción y elaboración de los mismos.

- Los colores (identidad cromática)

En cuanto a los colores corporativos, Candela Perú utiliza dos colores predominantes: el amarillo y el marrón, colores que por sus tonalidades cálidas se pueden asociar a lo natural y terreno.

\section{Producto \\ - Empaque}

El producto se presenta en un envase de vidrio circular y cuenta con presentaciones de 140,450 y $680 \mathrm{ml}$.

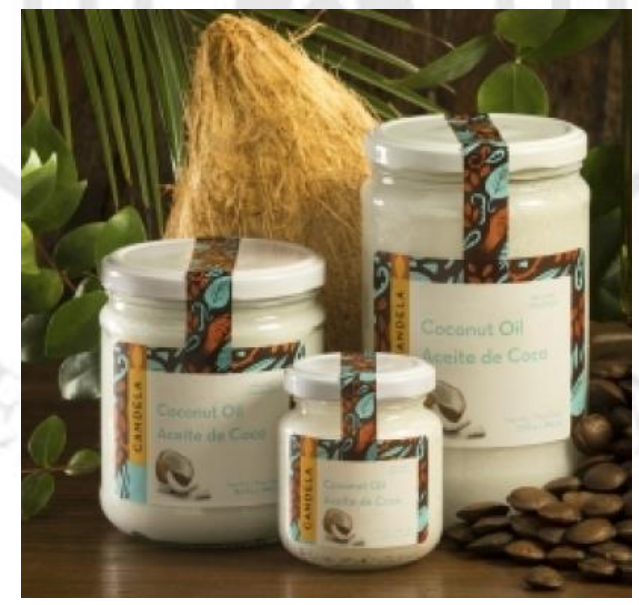

- Diseño

En el diseño de la etiqueta podemos apreciar diferentes elementos. Vemos la imagen del coco abierto, que es de donde procede el producto. La etiqueta tiene un fondo blanco y un tramado alrededor que contiene las imágenes de unas hojas, manos, hojas y cocos, elementos presentes en el proceso de obtención del aceite de coco. El logotipo se encuentra en vertical al lado izquierdo. El nombre del producto se coloca en español y en 
inglés, así como las características del producto y la categoría de orgánico. Se utiliza el turquesa como color complementario tanto en la texto como en el tramado.

\section{- Precio}

El precio del producto varía según la presentación de este: la de $140 \mathrm{ml}$ cuesta S/18; la de $450 \mathrm{ml}, \mathrm{S} / 48$; y la de $680 \mathrm{ml}, \mathrm{S} / 65$.

\section{- Distribución}

Candela Perú se dedica en gran parte a ventas al por mayor y a granel que atienden pedidos para negocios como tiendas, restaurantes, tiendas online, etc.

No cuenta con una tienda propia, pero venden sus productos en tiendas como BIOBODEGA, Madre Natura, Flora\&Fauna, Thika Thani Market, Mara Biomarket, La Bodega Orgánica, Yauvana, y El Ekeko. Además, participan en las bioferias de Miraflores y Surquillo ofreciendo sus productos en un stand.

Cuentan también con un servicio de delivery del producto, para pedidos a partir de los $\mathrm{S} / 250$ soles.

\section{Canales de comunicación}

\section{A. Página web}

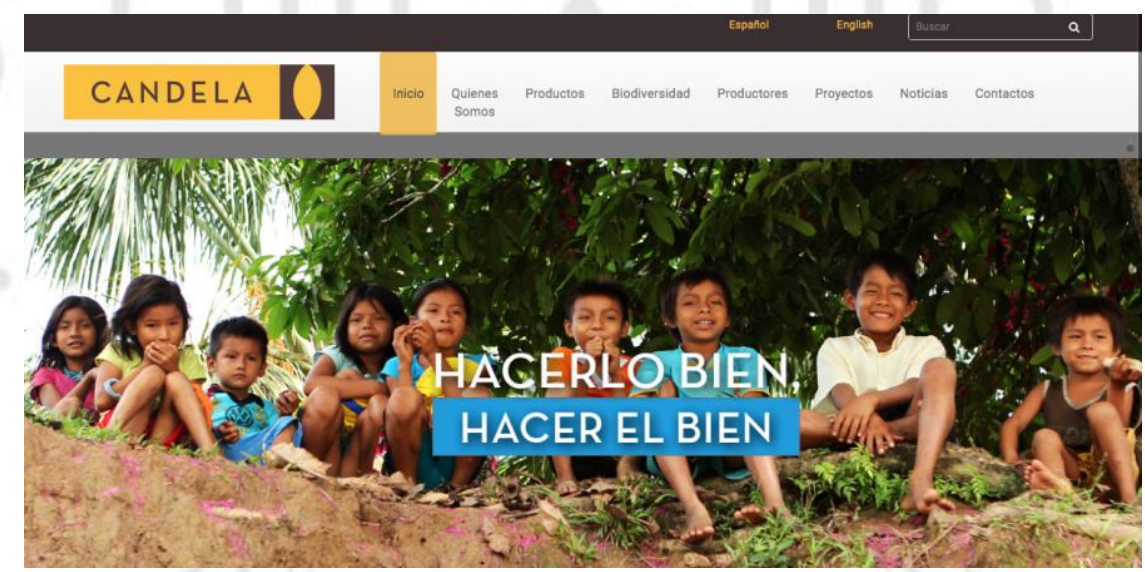

Candela Perú cuenta con una página web donde se puede encontrar información de la empresa, sus productos, y contenido relacionado a la biodiversidad, sus productores y los proyectos que tienen con la comunidad.

La página web posee los siguientes encabezados: Inicio, Quiénes Somos, Productos, Biodiversidad, Productores, Proyectos, Noticias y Contacto.

En la pestaña "Inicio" se puede encontrar un slider con fotos de sus productos y frases relacionadas a su misión, entre ellas, su eslogan. Además, cuenta con una sección de productos destacados, y finalmente las principales noticias. 
En "Quiénes Somos", encontramos el catálogo de la empresa (descargable), información de la misión, visión, certificaciones, historia, reporte de sostenibilidad, alianzas estratégicas, apariciones en prensa y las oportunidades laborales en la empresa.

En "Productos", se encuentra el contenido según la clasificación de tipo de producto entre productos a granel y productos a detalle. Dentro de cada una de estas secciones se encuentran el listado de productos, con un vínculo propio donde se coloa información detallada del producto como la descripción, ingredientes, procedencia, presentación, beneficios y usos.

En la pestaña "Biodiversidad" se encuentra información sobre cada cultivo de donde provienen sus productos.

En "Productores", se muestra información sobre los productores en las comunidades donde se encuentra la empresa, así como la cadena de valor. En "Proyectos", se encuentra la descripción de los distintos proyectos que tienen con las comunidades y ecosistemas de la zona.

En la pestaña "Noticias" encontramos noticias relevantes sobre la empresa; y en "Contacto", se indica la dirección de los locales de la empresa en Lima y Madre de Dios, un mapa de ubicación y un formulario de contacto.

En el footer de la página se encuentran los enlaces a sus redes sociales: Facebook, Instagram y YouTube.
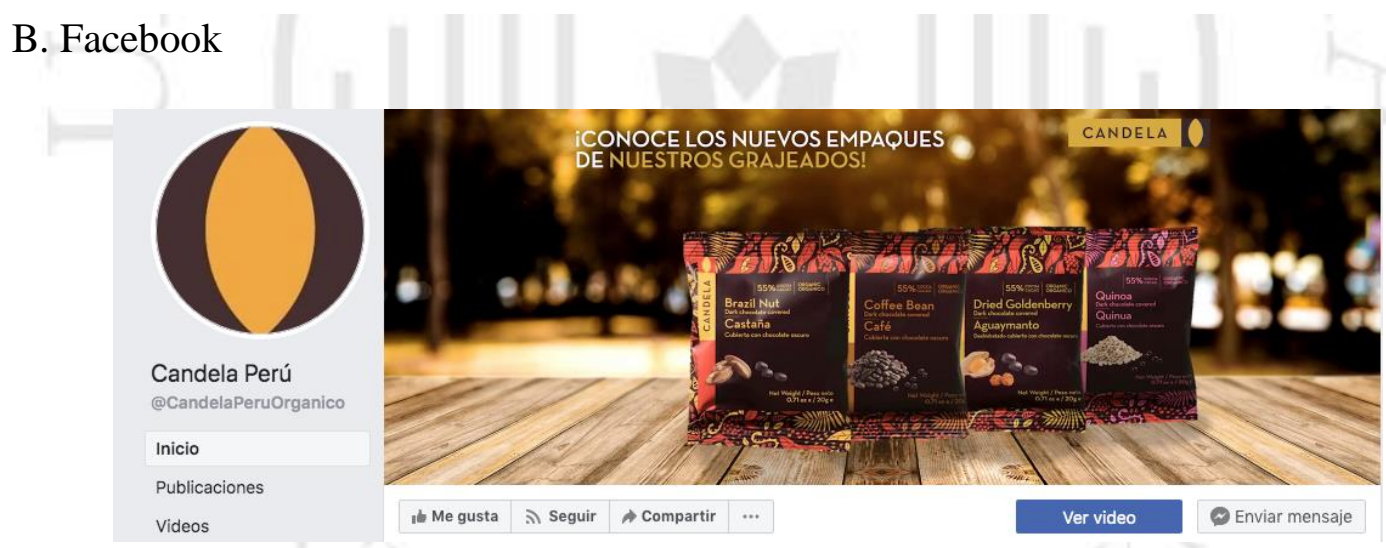

El fanpage de Candela Perú cuenta con 7,674 seguidores. Cuenta con diversas publicaciones: invitaciones a eventos y degustaciones, anuncios sobre nuevos puntos de venta de sus productos, publicaciones llamadas "Candela en tu día" donde colocan contenido sobre cómo utilizar sus productos en el día a día, así como recetas.

Utilizan mucho los hashtags para clasificar sus publicaciones, y para los nombres de sus productos. Además, cuentan con plantillas específicas para cada tipo de publicación, por lo que el muro se ve ordenado y coherente con su identidad gráfica.

\section{Instagram}


Candela Perú tiene un perfil en Instagram recientemente creado para el lanzamiento de la nueva imagen de sus productos. Cuenta con 2,122 seguidores y ha realizado 45 publicaciones, principalmente del nuevo empaque y del producto en sí.

Utiliza la herramienta de Stories para colocar información adicional de sus productos, así como compartir sus participaciones en ferias y eventos.

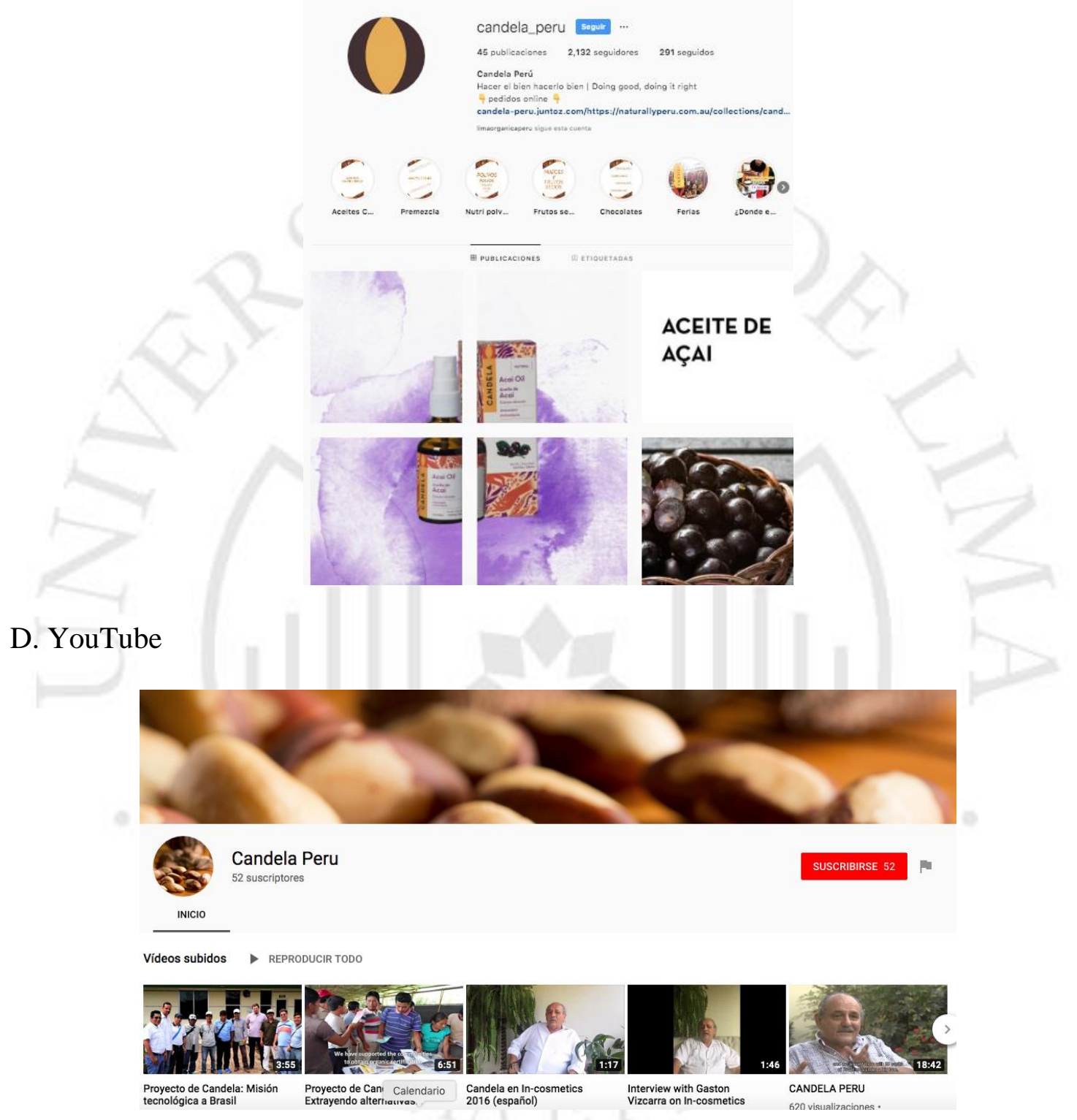

Candela Perú cuenta con un canal de YouTube donde tienen 52 suscriptores. Allí suben videos sobre la empresa, sus proyectos, sus productores, entrevistas, y con contenido a favor del cuidado de la biodiversidad. Hace dos años que no suben nuevo contenido. 
- Flora\&Fauna

1. Descripción de la empresa, filosofía

Flora \& Fauna es un mercado saludable especializado en la venta de productos orgánicos y libres de pesticidas, productos de belleza con ingredientes naturales, entre otros.

Propósito

Buscamos mejorar la salud de las personas, de los animales y del planeta ofreciendo alimentos y productos saludables, éticos y sostenibles.

Misión

Queremos ofrecer el mayor y mejor surtido de productos saludables, de manera transparente, eficiente y ecológica a través de una gratificante experiencia de compra.

Visión

Deseamos ser un promotor importante de la alimentación saludable y consumo consciente en el país, el socio de preferencia de los productores y fabricantes a nivel nacional y una voz influyente en el desarrollo de la industria saludable y responsable en el Perú.

Fuente: http://florayfauna.pe/

2. Servicios que ofrece

Flora \& Fauna ofrece una serie de productos orgánicos en las siguientes categorías:

- Frutas y verduras

- Comestibles

- Carnes, huevos, lácteos y alternativas

- Cuidado personal

- Limpieza

- Hogar

- Mascotas

- Alma botánica: suplementos

3. Imagen corporativa

- El nombre de la empresa: Flora \& Fauna

- El logo y otros símbolos

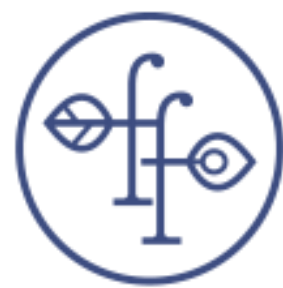


- El eslogan

Mercado saludable. La empresa también utiliza la frase "Somos Flora \& Fauna, somos tierra, somos todos" en su web para hacer referencia al origen de su producto y la comunidad que buscan formar en torno a la alimentación responsable y consumo consciente en el país.

- Los colores (identidad cromática)

El color predominante es el azul grisáceo tanto en su logotipo, como en su página web. Tiene como colores complementarios la crema y el gris oscuro.

\section{Producto}

La marca de aceite de coco que ofrece Flora \& Fauna es Peruvian Health, la cual ya ha sido descrita líneas arriba.

\section{- Distribución}

Cuenta con tres locales en la ciudad de Lima:

- Av. Mariscal La Mar 1110, Miraflores

- Av. Aviación 3110, San Borja

- Av. Primavera 654, Surco

También es posible hacer un pedido por delivery a través del celular, el cual tiene cobertira a todo Lima. 
5. Canales de comunicación

A. Página web

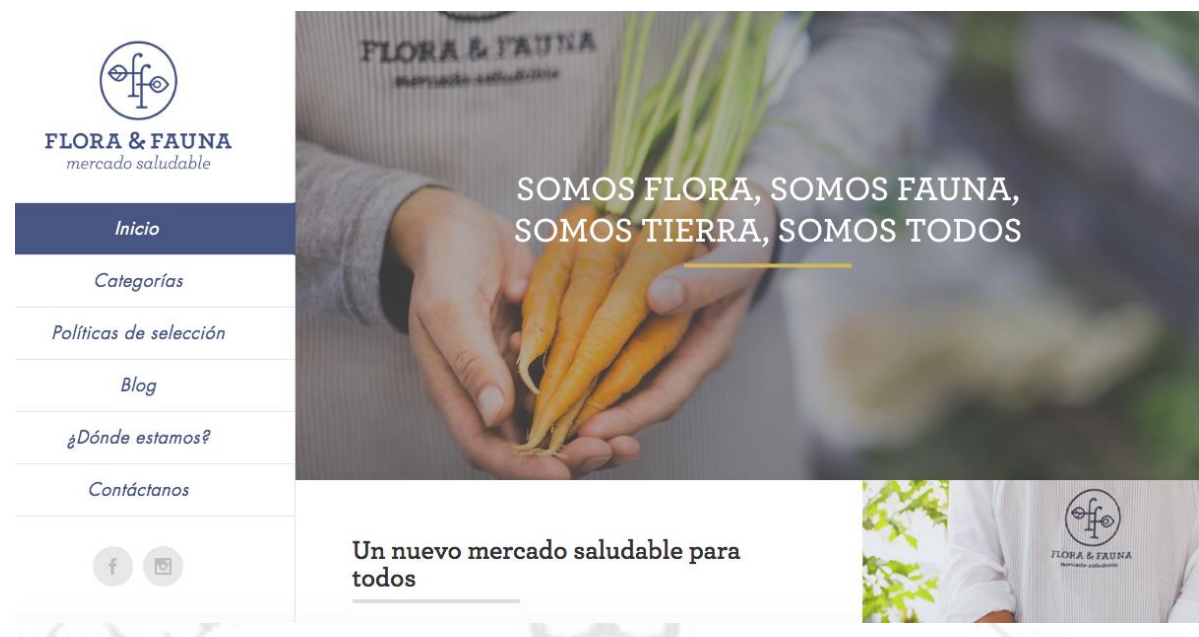

Flora \& Fauna cuenta con una página web que contiene información sobre la empresa, los productos que ofrece e información relacionada a la vida saludable y el consumo de productos orgánicos y naturales.

La página web posee los siguientes encabezados: Inicio, Categorías, Políticas de selección, Blog, ¿Dónde estamos?, y Contáctanos.

En la pestaña de Inicio se encuentra la descripción de lo que hace la empresa, su propósito, su misión y su visión.

En la sección Categorías se encuentra información referente a las categorías de productos que ofrecen y el detalle de los mismos.

En Políticas de selección se listan las características que tienen sus productos para estar incluidos dentro de su cartera.

La sección Blog contiene notas y artículos clasificados en tres categorías: Recetas, Bienestar y Estilo de vida.

En la pestaña ¿Dónde estamos? está la ubicación de los locales con un mapa. En Contáctanos hay un formulario para enviar consultas. Además, se indica que hay dos correos de contacto, uno para consultas generales (hola@florayfauna.pe) y otro para proveedores (comercial@ florayfauna.pe).

Cabe recalcar que en todas las páginas se encuentra un banner con la información de correo, teléfono y ubicación de los locales. 
B. Facebook

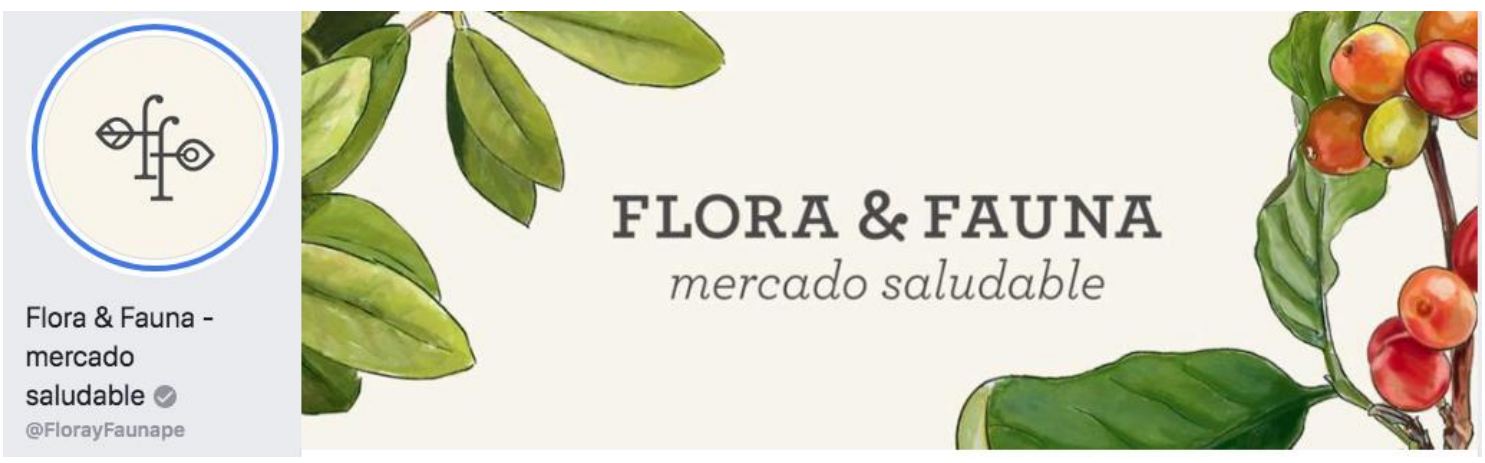

La página en Facebook de Flora \& Fauna cuenta con 106.354 seguidores. En sus publicaciones predomina el uso de fotografías, aunque cuentan con algunas plantillas gráficas para sus anuncios de eventos propios, talleres, horario de atención. Publican testimonios sobre vida saludable por parte de eco bloggers y coaches.

C. Instagram

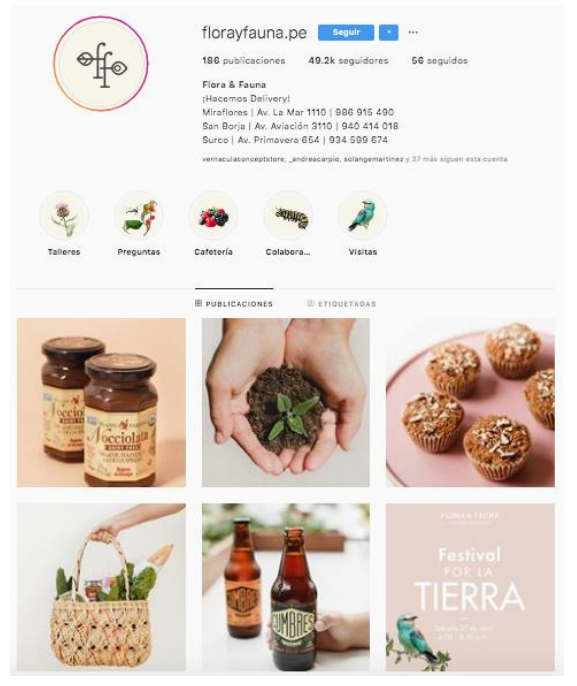

Flora \& Fauna tiene una cuenta en Instagram con 49.2 mil seguidores. En ella, rebotan el contenido publicado en su Facebook, así como historias destacadas donde utilizan plantillas específicas para: Talleres, Preguntas, Cafetería, Colaboradores y Visitas. 


\section{CAPÍTULO III: DIAGNÓSTICO DE LA SITUACIÓN ACTUAL}

\section{DAFO Cruzado}

A continuación, se procederá a identificar las principales fortalezas, debilidades, oportunidades y amenazas que la empresa atraviesa actualmente:

\section{Fortalezas:}

Del producto:

- El producto es orgánico y se produce en condiciones amigables con el medioambiente.

- El aceite de coco se obtiene de un producto primario al que la organización tiene acceso.

- El producto cuenta con diversas formas de uso: alimenticias, cosméticas y cuidado personal, industrial.

- Atributos positivos como la limpieza, frescura y naturalidad son prioridad para la producción del aceite.

- El método de procesamiento para el producto (Método Directo de Micro Expulsión o Direct Micro Expelling) permite conservar el sabor, calidad nutricional y frescura del producto.

- Fertilidad y nutrientes otorgados por la tierra de la selva peruana como valor agregado.

De la organización:

- Trayectoria de la empresa familiar. Cumplen 20 años en el 2020.

- Inicio de la empresa basada en una filosofía eco-amigable y la vida saludable de los peruanos alineada a las tendencias del mercado actuales.

- Son los mismos socios los que realizaron el procesamiento de la fruta desde sus inicios, garantizando la calidad de su producción.

- Dos de los tres socios viven en San Martín, lo cual permite la sostenibilidad en el control de la calidad de producción.

- El socio que se encuentra en Lima realiza de manera exitosa la venta de sus productos. Como relacionista público promueve la buena imagen de la organización mediante el trato personal con los clientes, abriendo nuevas oportunidades para contactos.

- Comunicación cercana con el cliente mediante los canales de la empresa.

- Cuentan con una tienda física en Surquillo, Lima.

- El 50\% de los colaboradores son millennials, al igual que el público objetivo.

- Motivación de los socios por mejorar la comunicación interna.

- Estrecha relación de casi 10 años con las comunidades productoras de Coco Bosque con las que se mantiene una alianza (ONG AMPA), contribuyendo a su sostenibilidad.

- Las comunidades de la selva con las que se trabaja conjuntamente, cuentan con la misma concientización ambiental, el consumo responsable para la preservación de los ecosistemas y el valor de la selva.

- La empresa está comprando además otros productos como el carbón de coco, 
hecho con los residuos de la materia prima.

- Los socios muestran apertura al cambio y la posibilidad de incorporar mayor tecnología en los procesos.

De la marca:

- Reconocimiento de la marca en bioferias y entre los principales clientes.

- Clientes fidelizados que corresponden al 30\% de las ventas.

- La recomendación del producto ha generado un $20 \%$ de las ventas.

\section{Debilidades:}

- Falta de una investigación de mercado donde la empresa reconozca el público que compra el aceite de coco.

- La empresa ha crecido sin un propósito organizacional claro.

- Falta de identificación, unidad y empatía de las necesidades y realidades entre los colaboradores de San Martin y los de Lima.

- Dificultades con la calidad de los envíos a otras provincias del Perú, generando mermas.

- Primera caída de ventas de la empresa (10\%) en el 2018.

- Los nuevos accionistas que ingresarán al negocio no se encuentran completamente alineados con la estrategia de los socios fundadores de apalancarse en la comunicación.

\section{Oportunidades:}

Del consumidor:

- Incremento de preferencia y percepción positiva hacia el consumo de productos orgánicos, frescos o saludables a nivel global.

- Tendencias orientadas en la producción y consumo ecoamigable en la industria alimenticia e industrial y en el consumo personal, respectivamente.

- Incremento en el uso del internet como fuente de información y reflexión sobre la salud.

- Los consumidores millennials presentan un uso constante de las redes sociales donde generan interacción.

- Influencers como estrategia para acercar al público a la marca y generar posicionamiento.

- Tendencia del consumidor millenial por compartir en sus redes productos alimenticios o de uso personal.

- La aplicación de la tecnología en la organización favorece el incremento de la productividad y competitividad, potencia la innovación, gestión de información, favorece la movilidad de la empresa y mejora la marca de la empresa.

Del mercado:

- Identificación de una gran demanda de productos ecológicos en el extranjero (Producto bandera - Marca Perú).

- Crecimiento del mercado de comida orgánica a través de bioferias, tiendas y restaurantes, así como empresas dedicadas a su comercialización.

- Mayor disposición de gasto por la compra de productos ecológicos. 
- En Coco Bosque, ubicado en la provincia de San Martín se produce, además del aceite de coco, otros productos naturales. Estos se están convirtiendo en una actividad sustentable para la región.

De la industria:

- En el país se produce alrededor de 35 mil toneladas de coco al año donde el $0.04 \%$ (de la producción nacional de aceites vegetales) se utiliza para la industria del aceite de coco.

- Creciente número de hectáreas destinadas a cultivos orgánicos.

Del gobierno:

- Tendencia a la regulación y fomento de distintas leyes frente al cultivo orgánico.

- Nuevas políticas y estrategias del Gobierno y entidades relacionadas frente a la producción y consumo de productos agrícolas.

\section{Amenazas:}

- Picota, la provincia más fértil en San Martín para producir este producto está amenazado por la deforestación.

- La demanda del aceite de coco no está siendo cubierta por la producción nacional, teniendo como resultado un crecimiento sostenido de la importación en los últimos 4 años.

- Empresas ilegales y migrantes que amenazan con la deforestación.

- Apertura de supermercados y tiendas grandes de productos orgánicos en el año 2018.

\section{Cruce:}

Estrategias FO (usar fortalezas para aprovechar oportunidades)

- Apalancarnos de la creciente tendencia hacia la alimentación y consumo orgánico presente en nuestro público objetivo, ya que ella está alineada con nuestra filosofía eco-amigable y nuestro producto $100 \%$ orgánico.

- Aplicar la tecnología para agilizar los procesos, potenciar la interacción entre los colaboradores y desarrollar estrategias que permitan utilizar los medios digitales y otros soportes tecnológicos como herramientas para comunicar los atributos del producto.

- Valernos de la experiencia, conocimiento y contactos de los socios para generar experiencias de valor que incentiven una relación más estrecha entre el producto y los grupos de interés de la empresa.

- Posicionarnos como una empresa familiar emprendedora que apuesta por la producción nacional de productos orgánicos como negocio responsable y sostenible que contribuye al desarrollo personal y profesional de las comunidades productoras.

- Aprovechar el reconocimiento de la marca en los clientes de las bioferias y el uso constante de las redes sociales por parte de ellos para transmitir sus experiencias positivas con el producto en el entorno digital. 
- Lograr alianzas estratégicas para que nuestros productos tengan un mayor alcance en el mercado.

Estrategias DO (superar debilidades aprovechando oportunidades)

- Crear una identidad corporativa que logre la identificación de los colaboradores, clientes y comunidad con la empresa.

- Apostar por la investigación de mercado para conocer a nuestro público objetivo y así ofrecerles una propuesta de valor ad hoc, así como mapear los acontecimientos en el mercado que puedan afectarnos.

- Trabajar de la mano con una empresa dedicada a la comercialización de productos ecológicos que conozca a fondo las mejores prácticas y condiciones para mantener la integridad del producto.

Estrategias FA (usar fortalezas para evitar amenazas)

- Trabajar junto a la comunidad de Coco Bosque para incentivar el cuidado de los ecosistemas y la sostenibilidad de las parcelas donde se cultiva el coco para contrarrestar la deforestación.

- Promover el consumo de productos orgánicos nacionales de calidad que estén alineados a nuestra identidad.

Estrategias DA (reducir debilidades y evitar amenazas)

- Alinear la estrategia de los nuevos accionistas con la de los socios fundadores para mantener la esencia de la marca y el producto en su crecimiento en el tiempo. 


\section{FODA cruzado con los problemas del negocio}

A continuación, se alinearán las estrategias identificadas en el FODA cruzado con los problemas del negocio.

I. Crecimiento de la empresa sin un propósito organizacional claro dada las diferentes necesidades y realidades de sus colaboradores en sus sedes de San Martín y Lima.

- Posicionarnos como una empresa familiar emprendedora que apuesta por la producción nacional de productos orgánicos como negocio responsable y sostenible que contribuye al desarrollo personal y profesional de las comunidades productoras.

- Crear una identidad corporativa que logre la identificación de los colaboradores, clientes y comunidad con la empresa.

- Alinear la estrategia de los nuevos accionistas con la de los socios fundadores para mantener la esencia de la marca y el producto en su crecimiento en el tiempo.

II. Carecimiento de un valor diferencial de la organización que inspire tanto interna como externamente.

- Apalancarnos de la creciente tendencia hacia la alimentación y consumo orgánico presente en nuestro público objetivo, ya que ella está alineada con nuestra filosofía eco-amigable y nuestro producto $100 \%$ orgánico.

- Valernos de la experiencia, conocimiento y contactos de los socios para generar experiencias de valor que incentiven una relación más estrecha entre el producto y los grupos de interés de la empresa.

- Trabajar junto a la comunidad de Coco Bosque para incentivar el cuidado de los ecosistemas y la sostenibilidad de las parcelas donde se cultiva el coco para contrarrestar la deforestación.

- Promover el consumo de productos orgánicos nacionales de calidad que estén alineados a nuestra identidad.

III. Desconocimiento del público que consume su producto y sus características.

- Apostar por la investigación de mercado para conocer a nuestro público objetivo y así ofrecerles una propuesta de valor ad hoc, así como mapear los acontecimientos en el mercado que puedan afectarnos.

IV. Pérdida de producción en el envío de productos a las ciudades de Arequipa, Trujillo y Cusco por la incorrecta manipulación del producto.

- Trabajar de la mano con una empresa dedicada a la comercialización de productos ecológicos que conozca a fondo las mejores prácticas y condiciones para mantener la integridad del producto.

V. Caída de $10 \%$ en las ventas debido al crecimiento del mercado del aceite de coco en supermercados y tiendas.

- Aprovechar el reconocimiento de la marca en los clientes de las bioferias y el uso constante de las redes sociales por parte de ellos para transmitir sus experiencias positivas con el producto en el entorno digital.

- Lograr alianzas estratégicas para que nuestros productos tengan un mayor alcance en el mercado.

Transversalmente, se aplicará la tecnología para agilizar los procesos, potenciar la interacción entre los colaboradores y desarrollar estrategias que permitan utilizar los medios digitales y otros soportes tecnológicos como herramientas para comunicar los atributos del producto, generando enganche y fidelización. 


\section{Canales de comunicación}

La empresa Coco Peruano cuenta con los siguientes canales de comunicación:

- Vía telefónica: clientes asiduos realizan sus pedidos por teléfono.

- Boca a boca: recomendación del producto y canal para mantener la relación del socio en Lima con los colaboradores, bioferias y consumidores.

- WhatsApp: recibimiento de pedidos.

- Periódico mural: renovación del mismo cada tres o cuatro meses.

- Revista: editada 3 veces al año.

Es importante recalcar, la importancia del canal telefónico, mediante llamadas y WhatsApp, para la venta del aceite de coco, así como el word of mouth que se produce gracias a las experiencias positivas y satisfechas de los consumidores con el producto; aspecto que impacta en las ventas y genera reconocimiento y, luego, fidelización en la marca.

\section{Mapeo de stakeholders}

\begin{tabular}{|c|c|c|c|}
\hline $\begin{array}{l}\text { Grupo de } \\
\text { interés }\end{array}$ & Tipo & Descripción & $\begin{array}{c}\text { Expectativas y } \\
\text { necesidades }\end{array}$ \\
\hline Socios & Primario & $\begin{array}{l}\text { - } 3 \text { socios principales } \\
\text { (hermanos) } \\
\text { - Nuevos accionistas }\end{array}$ & $\begin{array}{l}\text { Los socios actuales } \\
\text { tienen una expectativa } \\
\text { alta hacia la empresa y la } \\
\text { nueva dirección que } \\
\text { quieren } \\
\text { utilizando asumir, } \\
\text { comunicación de manera } \\
\text { estratégica para ser más } \\
\text { competitivos y mejorar } \\
\text { su relación con sus } \\
\text { grupos de interés. } \\
\text { Los nuevos accionistas } \\
\text { también tienen una } \\
\text { expectativa alta pues } \\
\text { buscan a obtener } \\
\text { resultados } \\
\text { justifiquen su inversión } \\
\text { de capital. }\end{array}$ \\
\hline Colaboradores & Primario & $\begin{array}{l}53 \quad \text { colaboradores } \\
\text { distribuidos entre sus sedes } \\
\text { en Lima y San Martín. } \\
\text { Áreas: }\end{array}$ & $\begin{array}{l}\text { Dependiendo del área en } \\
\text { la que se desempeñan, } \\
\text { sus expectativas varían: }\end{array}$ \\
\hline
\end{tabular}




\begin{tabular}{|c|c|c|c|}
\hline$\theta$ & & 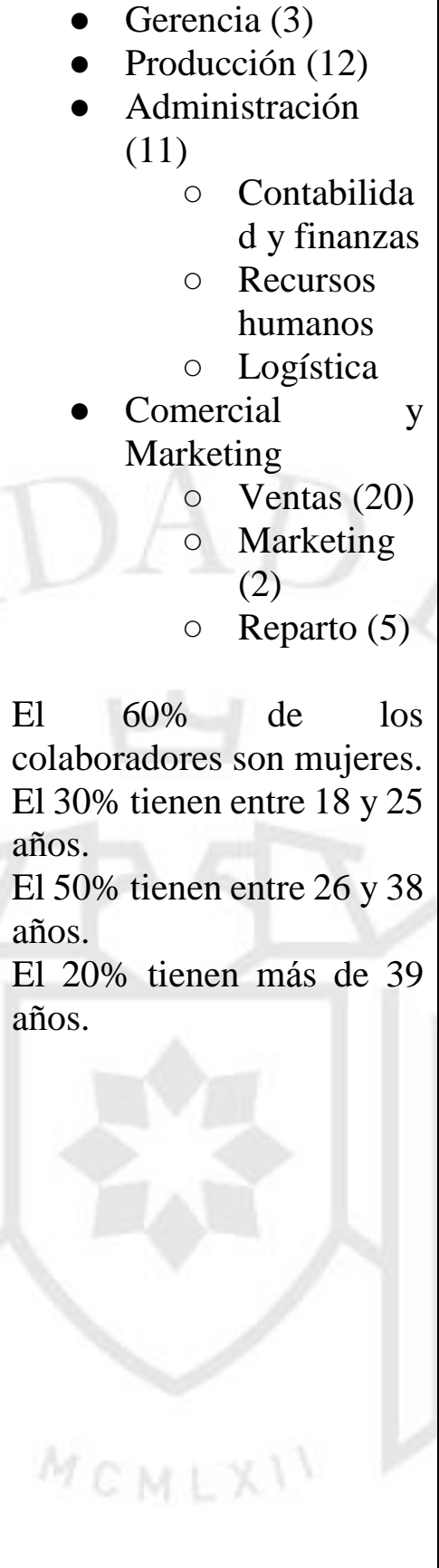 & $\begin{array}{l}\text { Los colaboradores en } \\
\text { áreas administrativas } \\
\text { esperan de la empresa } \\
\text { claridad sobre sus } \\
\text { funciones, roles y } \\
\text { desempeño para lograr } \\
\text { los objetivos } \\
\text { organizacionales. Deben } \\
\text { estar comprometidos con } \\
\text { la nueva filosofía } \\
\text { corporativa. } \\
\text { Los colaboradores en } \\
\text { producción tienen una } \\
\text { alta expectativa por } \\
\text { conocer el impacto de su } \\
\text { labor y desarrollar } \\
\text { capacidades que los } \\
\text { ayuden a hacer cada vez } \\
\text { mejor su trabajo. Buscan } \\
\text { que su trabajo sea } \\
\text { valorado. } \\
\text { Los colaboradores en las } \\
\text { áreas de ventas tienen la } \\
\text { expectativa de que la } \\
\text { empresa a la que } \\
\text { representan y el producto } \\
\text { que ofrecen sea bueno y } \\
\text { de calidad, acorde a la } \\
\text { filosofía que la empresa } \\
\text { busca compartir. Buscan } \\
\text { contar con metas claras } \\
\text { de ventas e incentivos } \\
\text { que los motiven a } \\
\text { superarlas. }\end{array}$ \\
\hline Proveedores & Primario & $\begin{array}{l}\text { Proyecto Coco } \\
\text { Bosque: La } \\
\text { empresa les compra } \\
750 \text { litros de aceite } \\
\text { de coco al mes. } \\
\text { - Flora Courier (para } \\
\text { envíos de delivery } \\
\text { en Arequipa, } \\
\text { Trujillo y Cusco). }\end{array}$ & $\begin{array}{l}\text { Los proveedores tienen } \\
\text { una expectativa alta pues } \\
\text { deben estar alineados a } \\
\text { los cambios o mejoras } \\
\text { que se implementen } \\
\text { como empresa. } \\
\text { Asimismo, deben } \\
\text { conocer la filosofía } \\
\text { corporativa para poder } \\
\text { compartirla. }\end{array}$ \\
\hline Clientes & Primario & $\begin{array}{l}\text { Target: Hombres y mujeres } \\
\text { entre los } 21 \text { y } 35 \text { años de }\end{array}$ & $\begin{array}{l}\text { Los clientes tienen la } \\
\text { necesidad de adquirir un }\end{array}$ \\
\hline
\end{tabular}




\begin{tabular}{|c|c|c|c|}
\hline & & $\begin{array}{l}\text { NSE AB que residen en } \\
\text { Lima. } \\
\text { Personas que tienen una } \\
\text { preocupación por el } \\
\text { cuidado del } \\
\text { medioambiente y tener un } \\
\text { estilo de vida saludable } \\
\text { basado en un consumo } \\
\text { responsable de productos. } \\
\text { Asisten a bioferias } \\
\text { (Barranco, Miraflores, } \\
\text { Surquillo, Pueblo Libre, } \\
\text { Lince, La Molina, entre } \\
\text { otros). }\end{array}$ & $\begin{array}{l}\text { producto saludable que } \\
\text { los ayude a vivir el } \\
\text { consumo responsable. } \\
\text { Buscan estar informados } \\
\text { sobre el producto y el } \\
\text { impacto que su consumo } \\
\text { implica. }\end{array}$ \\
\hline Comunidad & Secundario & $\begin{array}{l}\text { Distritos aledaños donde } \\
\text { se encuentran sus locales: } \\
\text { En Lima: } \\
\text { - Surquillo } \\
\text { - San Isidro } \\
\text { - San Borja } \\
\text { - Miraflores } \\
\text { - } \text { Barranco } \\
\text { - Jesús María } \\
\text { En San Martín: } \\
\text { - Pobladores que } \\
\text { habitan en las } \\
\text { zonas donde la } \\
\text { empresa cosecha y } \\
\text { produce el aceite } \\
\text { de coco. } \\
\text { Pobladores que } \\
\text { habitan en las } \\
\text { zonas donde se } \\
\text { desarrolla el } \\
\text { proyecto Coco } \\
\text { Bosque }\end{array}$ & $\begin{array}{l}\text { Esperan que la empresa } \\
\text { tenga un } \\
\text { comportamiento } \\
\text { responsable con respecto } \\
\text { al espacio y población } \\
\text { que habita en donde se } \\
\text { desarrollan sus } \\
\text { actividades de } \\
\text { producción, distribución } \\
\text { y venta del producto. }\end{array}$ \\
\hline Medioambiente & Secundario & $\begin{array}{l}\text { Comprende el impacto } \\
\text { medioambiental de la } \\
\text { empresa en la zona de } \\
\text { influencia donde se } \\
\text { desarrollan sus actividades. }\end{array}$ & $\begin{array}{l}\text { Se espera que la empresa } \\
\text { desarrolle sus } \\
\text { actividades respetando el } \\
\text { medioambiente tanto en } \\
\text { sus procesos internos }\end{array}$ \\
\hline
\end{tabular}




\begin{tabular}{|c|c|c|c|}
\hline & & $\begin{array}{l}\text { A nivel interno, comprende } \\
\text { las acciones dentro de los } \\
\text { procesos y procedimientos } \\
\text { relacionados con el } \\
\text { consumo de recursos y } \\
\text { gestión de residuos. A nivel } \\
\text { externo, comprenden } \\
\text { acciones que generan } \\
\text { impacto medioambiental } \\
\text { en la producción, } \\
\text { distribución y venta de sus } \\
\text { productos. }\end{array}$ & $\begin{array}{l}\text { como en la cadena de } \\
\text { producción. Al ser este } \\
\text { grupo de interés parte de } \\
\text { su fulosofía, la } \\
\text { expectativa es alta. }\end{array}$ \\
\hline $\begin{array}{l}\text { Alianzas } \\
\text { estratégicas }\end{array}$ & Primario & 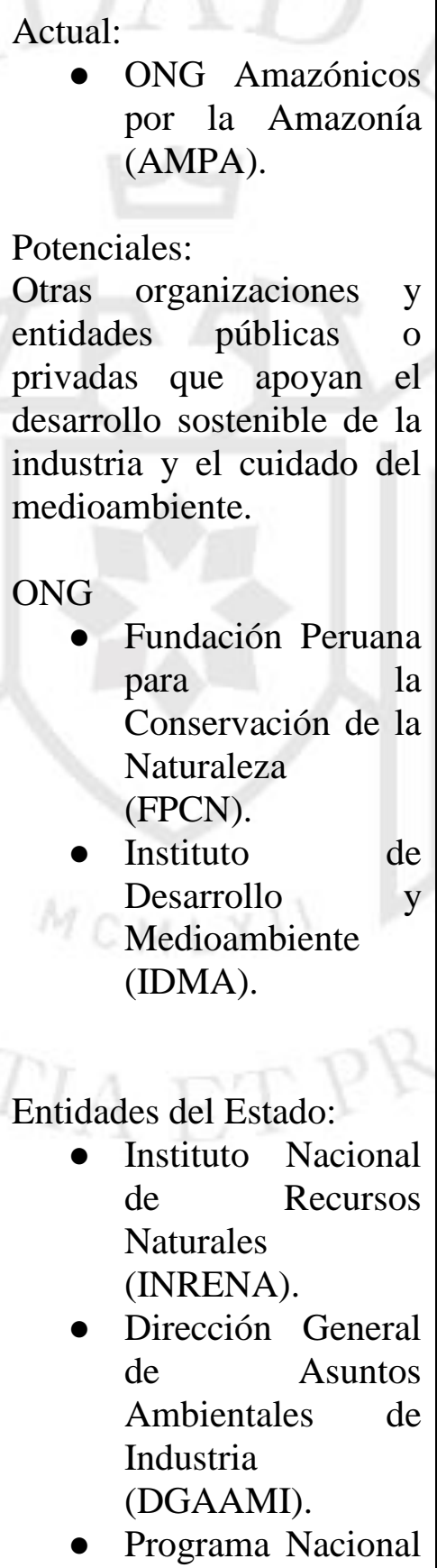 & $\begin{array}{l}\text { La expectativa de la } \\
\text { relación con esta alianza } \\
\text { estratégica es alta pues la } \\
\text { empresa depende de } \\
\text { ellos para su producción } \\
\text { del aceite de coco. }\end{array}$ \\
\hline
\end{tabular}




\begin{tabular}{|c|c|c|c|}
\hline & & $\begin{array}{l}\text { de Conservación de } \\
\text { Bosques para la } \\
\text { Mitigación del } \\
\text { Cambio Climático. }\end{array}$ & \\
\hline Competencia & Secundario & $\begin{array}{l}\text { Principales competidores } \\
\text { que venden aceite de coco: } \\
\text { - Peruvian Health } \\
\text { - Inkanat } \\
\text { - Veggispirit } \\
\text { - Candela Perú } \\
\text { - Bioselva } \\
\text { - Real Organic Perú } \\
\text { Tiendas que ofrecen } \\
\text { productos orgánicos: } \\
\text { - Tiendas Organa } \\
\text { - Flora\&Fauna }\end{array}$ & $\begin{array}{l}\text { La expectativa es medio } \\
\text { alta pues se debe tener } \\
\text { mapeados a los } \\
\text { competidores y sus } \\
\text { propuestas de valor para } \\
\text { que la empresa pueda } \\
\text { diferenciarse de cara al } \\
\text { consumidor. }\end{array}$ \\
\hline Gobierno & Secundario & 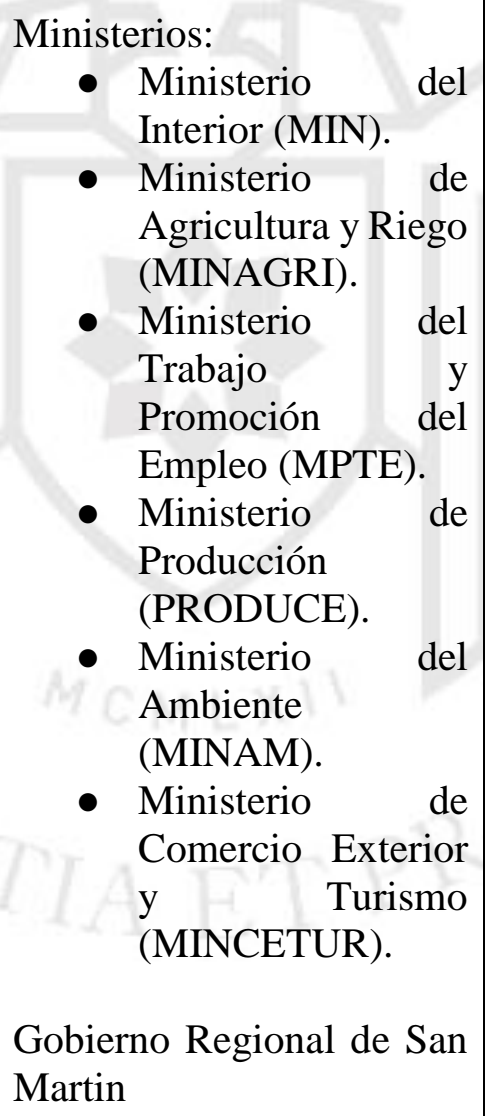 & $\begin{array}{l}\text { La expectativa de estas } \\
\text { entidades es media. La } \\
\text { empresa debe asegurarse } \\
\text { de cumplir con todas las } \\
\text { leyes y regulaciones que } \\
\text { se involucren con su } \\
\text { actividad. }\end{array}$ \\
\hline $\begin{array}{l}\text { Líderes } \\
\text { opinión }\end{array}$ & Secundario & $\begin{array}{l}\text { Influenciadores nacionales } \\
\text { ecoamigables y de wellness } \\
\text { life: } \\
\text { - Solange Martinez } \\
\text { (Armónica Café). }\end{array}$ & $\begin{array}{l}\text { La empresa puede } \\
\text { valerse de este grupo de } \\
\text { interés para su estrategia } \\
\text { de comunicación } \\
\text { externa, pues se } \\
\text { encuentran en tendencia. }\end{array}$ \\
\hline
\end{tabular}




\begin{tabular}{|c|c|c|c|}
\hline & & 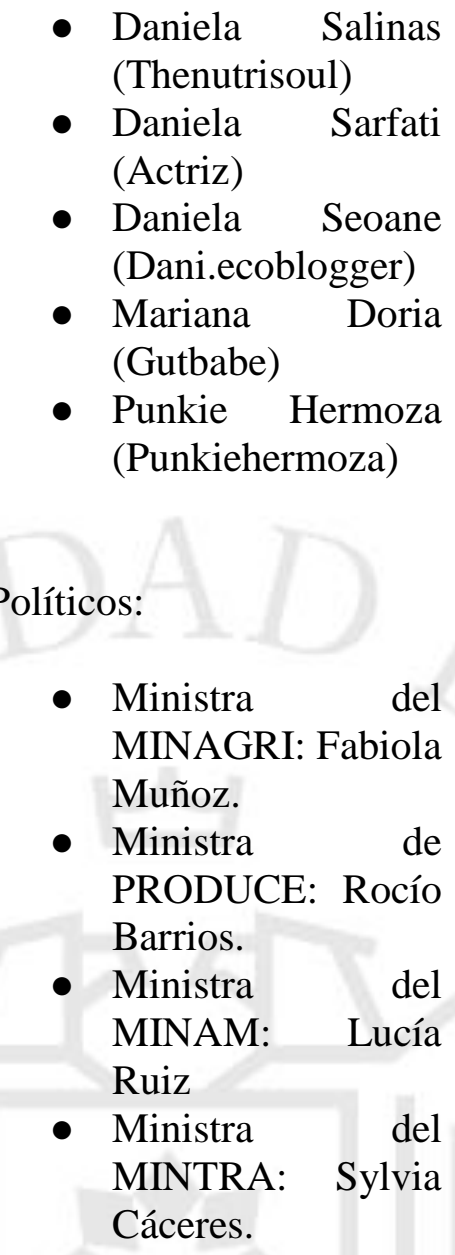 & + \\
\hline $\begin{array}{l}\text { Medios de } \\
\text { comunicación }\end{array}$ & Secundario & $\begin{array}{l}\text { - TV Perú } \\
\text { - El Comercio } \\
\text { Aptitus } \\
\text { A4 }\end{array}$ & $\begin{array}{l}\text { La expectativa de uso de } \\
\text { este grupo de interés es } \\
\text { baja ya que el tema del } \\
\text { consumo responsable } \\
\text { aún está posicionándose } \\
\text { a este nivel de } \\
\text { comunicación masiva. A } \\
\text { futuro, la empresa } \\
\text { podría evaluar buscar } \\
\text { relacionarse con ellos. }\end{array}$ \\
\hline
\end{tabular}




\section{Diagnóstico y problemas de comunicación:}

Nuestro plan estratégico de comunicación se basará en la aplicación de las estrategias identificadas tanto en el ámbito interno como externo, con el objetivo de que la comunicación se utilice de manera estratégica para apoyar al negocio en el cumplimiento de sus objetivos.

Es así, que las estrategias relacionadas a los problemas I, II y IV se abordarán desde una estrategia de comunicación interna que considere el rol del área de comunicaciones y otras áreas (como el área de producción), pues están orientadas a nuestro público interno (accionistas, colaboradores y proveedores); y las estrategias relacionadas a los problemas III y V se abordarán desde una estrategia de comunicación externa, al estar orientadas a nuestro público externo (clientes y comunidad).

Es así, que desde la comunicación se podrá ayudar a la empresa a abordar los siguientes problemas:

1. La organización mantiene, desde hace 19 años, una filosofía corporativa que está alineada a una tendencia creciente de vida saludable, mas no la está utilizando y comunicando como un aspecto diferenciador que inspire tanto interna como externamente.

2. El producto presenta diversos atributos como la calidad, trayectoria, su proceso agrícola, peruanidad, compromiso con las comunidades de la selva, entre otros. Estos pueden ser aplicados para la construcción del posicionamiento a comunicar.

3. Proyectar de manera homogénea la personalidad de marca Selva \& Salud, transmitiendo así la esencia, valores, tono y estilo de comunicación, que permitirán su identificación por los diferentes grupos de interés con los que interactúa, generando una experiencia única de marca.

4. La empresa mantiene un compromiso con las comunidades de Coco Bosque y la conservación del ecosistema en San Martín, aspectos que lo diferencian de sus consumidores y representan un valor agregado para la marca.

5. La empresa cuenta con clientes asiduos y el reconocimiento en las bioferias, no obstante, podría abordar esta fortaleza para difundir el producto y las experiencias positivas del mismo.

6. Los socios fundadores cuentan con una historia que representa la esencia de la organización, la cual podría ser utilizada como medio para generar pertenencia, identificación y crear una cultura medioambientalista.

7. La mayoría de canales de comunicación que la organización utiliza son de cara al cliente (personales) lo cual es una fortaleza pues se mantiene una relación mas cercana con el mismo. No obstante, se debe identificar cómo potenciarlos, agregar nuevos que sean interactivos tanto interna como externamente y retirar otros que no sean tan efectivos.

8. Aplicar la tecnología para agilizar los procesos, potenciar la interacción entre los colaboradores y desarrollar estrategias que permitan utilizar los medios digitales y otros soportes tecnológicos como herramientas para comunicar los atributos del producto, generando enganche y fidelización. 


\section{CAPÍTULO IV: PLAN ESTRATÉGICO DE COMUNICACIÓN JULIO 2019 - JULIO 2020}

\section{Objetivos de comunicación}

A partir del diagnóstico realizado de la situación actual y comunicacional de la empresa, se planteará un plan estratégico de comunicación para el periodo entre julio de 2019 y julio de 2020, que soporte al negocio en el logro de sus objetivos trazados.

\section{Objetivo general}

Diseñar una estrategia de comunicación que logre transmitir el propósito y propuesta de valor de la Selva \& Salud y potencie el engagement con sus stakeholders, de modo que se logre el crecimiento esperado de la empresa.

Para alcanzar este objetivo, se diseñará un plan de comunicación interna y otro de comunicación externa que abarquen los principales públicos. Se planteará un objetivo específico para cada plan, y dentro de cada uno se desarrollarán las estrategias y acciones que ayudarán a cumplirlos (todos descritos en sus respectivas matrices).

\section{Objetivo interno}

Involucrar a los colaboradores con la filosofía corporativa y la propuesta de valor de Selva \& Salud.

\section{Objetivos específicos internos}

Objetivo específico 1: Difundir la identidad y filosofía corporativa de Selva \& Salud a los colaboradores de sus dos sedes.

Objetivo específico 2: Interiorizar los valores corporativa en su aplicación diaria a través de la campaña "Nuestros valores $S \& S$ "

Objetivo específico 3: Relacionar a los colaboradores con la propuesta de valor de Selva \& Salud

\section{Objetivo externo}

Consolidar el posicionamiento de Selva \& Salud para generar una relación con sus públicos externos (clientes y proveedores).

\section{Objetivos específicos externos}

Objetivo específico 1: Dar a conocer la identidad corporativa de Selva \& Salud hacia sus clientes y proveedores.

Objetivo específico 2: Fortalecer la relación de Selva \& Salud con su público externo.

Objetivo específico 3: Construir un ecosistema digital sólido que permita el posicionamiento de Selva \& Salud en internet 


\section{Público objetivo}

a. Público interno

Colaboradores de Lima y San Martín que están distribuidos en las diferentes áreas.

b. Público externo

\section{Clientes}

Hombres y mujeres entre los 21 y 35 años de NSE AB que residen en Lima. Personas que tienen una preocupación por el cuidado del medioambiente y tener un estilo de vida saludable basado en un consumo responsable de productos. Asisten a bioferias (Barranco, Miraflores, Surquillo, Pueblo Libre, Lince, La Molina, entre otros).

Proveedores

Proyecto Coco Bosque: La empresa les compra 750 litros de aceite de coco al mes. Flora Courier (para envíos de delivery en Arequipa, Trujillo y Cusco).

Comunidad

Familias pertenecientes a Coco Bosque

\section{Indicadores}

a. Operativos: Con los indicadores operativos se mide el nivel de ejecución de un proyecto, actividad, taller, campaña, etc en referencia al número total de actividades.

b. Tácticos: Con los indicadores tácticas se pide una acción en concreta como el número de colaboradores que asistieron a un taller, personas que respondieron un correo, entre otros.

c. Cognitivos o de comportamiento: Los indicadores cognitivos permiten pedir el aprendizaje de una persona frente a una actividad, así como si se encuentra en un cambio en su comportamiento. Con este indicador se obtiene información más reflexiva e interna. Para poder obtenerla es necesario complementar la actividad con una herramienta de obtención de información como una trivia o encuesta de satisfacción donde se pueda reconocer la información indicada. 


\section{Planes de comunicación}

\subsection{Plan de comunicación interna}

\subsubsection{Objetivos del plan}

\section{Objetivo general:}

Involucrar a los colaboradores con la filosofía corporativa y la propuesta de valor de Selva \& Salud.

Objetivo específico 1: Difundir la identidad y filosofía corporativa de Selva \& Salud a los colaboradores de sus dos sedes.

Estrategia 1: Lanzamiento de la nueva identidad y filosofía corporativa en un evento donde participen todos los colaboradores

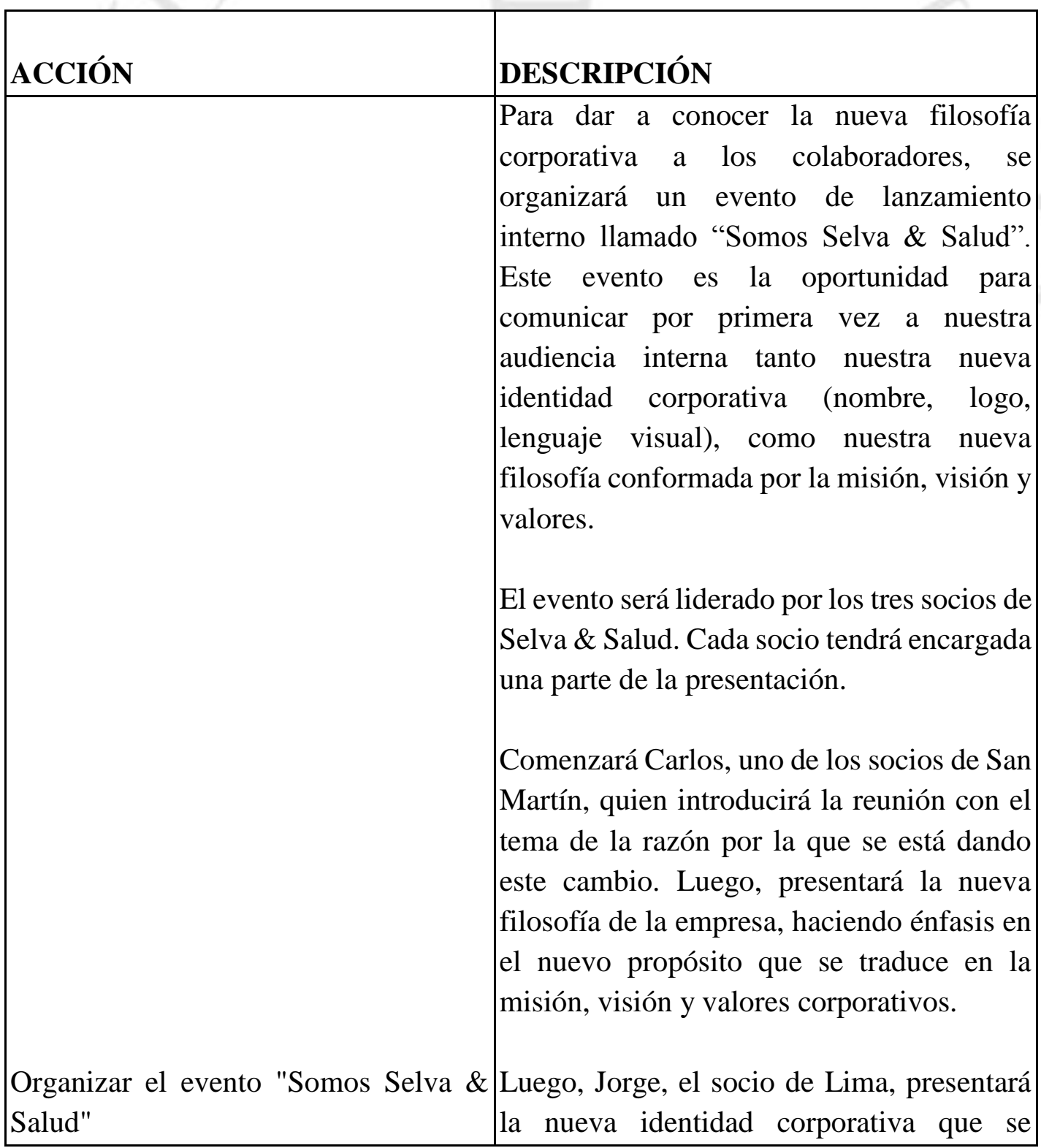




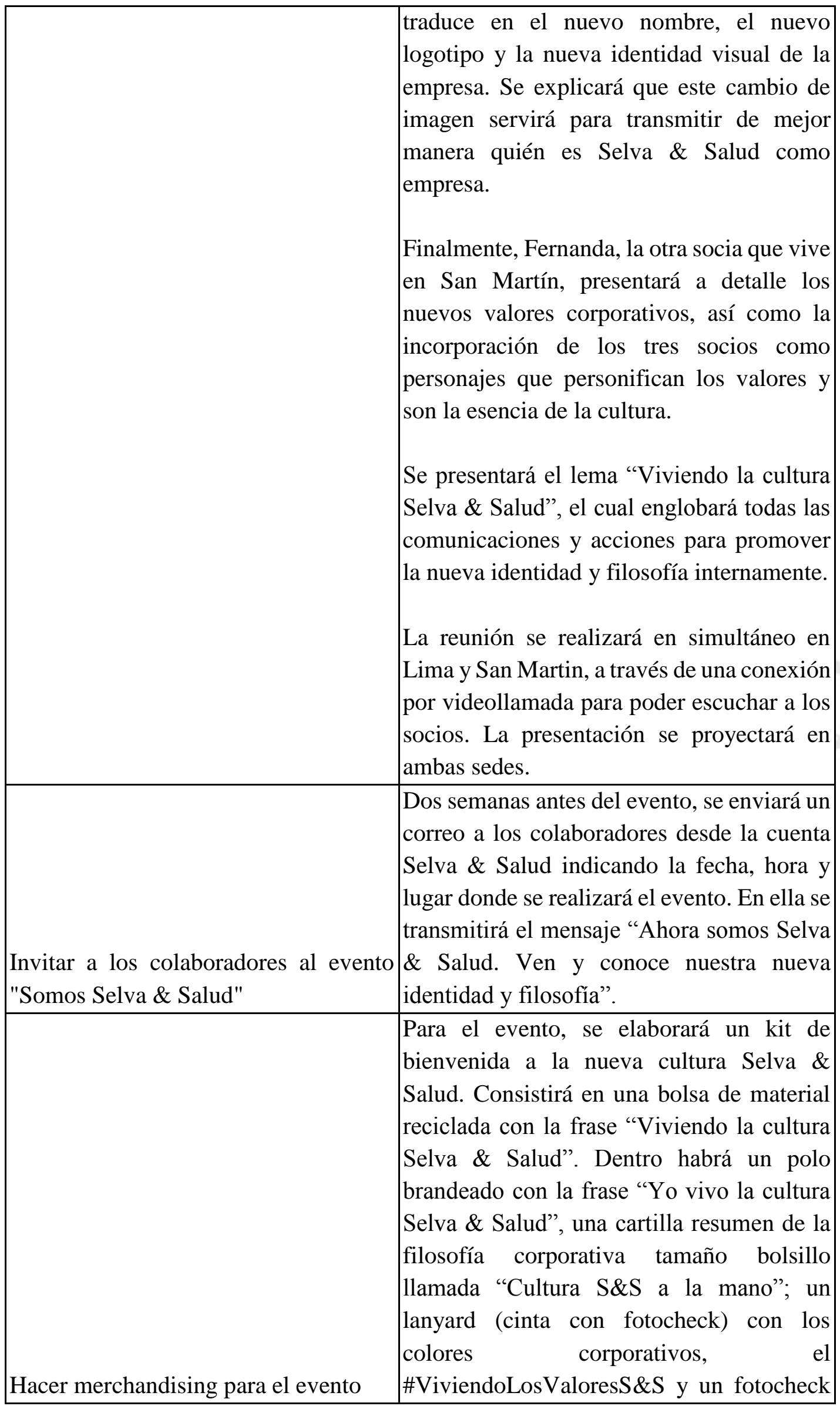




\begin{tabular}{|c|c|}
\hline & $\begin{array}{l}\text { hecho de material reciclado; y el díptico } \\
\text { corporativo. }\end{array}$ \\
\hline $\begin{array}{l}\text { Elaborar un díptico que contenga la } \\
\text { filosofía }\end{array}$ & $\begin{array}{l}\text { Se elaborará un díptico corporativo que } \\
\text { reúna de manera gráfica el propósito, } \\
\text { misión y visión de la empresa, así como sus } \\
\text { valores. }\end{array}$ \\
\hline Implementar viniles en las oficinas & $\begin{array}{l}\text { Luego del evento, se brandearán las oficinas } \\
\text { con la nueva identidad corporativa. Se } \\
\text { acondicionará un mural que incluya el } \\
\text { propósito, misión y visión. Los íconos que } \\
\text { corresponden a cada valor se colocarán en } \\
\text { la aplicación de la campaña "Nuestros } \\
\text { valores S\&S" del objetivo específico } 2 \text {. }\end{array}$ \\
\hline $\begin{array}{l}\text { Difundir el evento en nuestros canales } \\
\text { internos y externos }\end{array}$ & $\begin{array}{l}\text { Se tomarán fotos el día del evento, y se } \\
\text { grabarán testimonios de los colaboradores } \\
\text { que se compartirán luego por medio de los } \\
\text { canales internos y externos. }\end{array}$ \\
\hline $\begin{array}{l}\text { Incluir contenido relacionado en las } \\
\text { pautas de los canales internos de } \\
\text { comunicación }\end{array}$ & $\begin{array}{l}\text { Luego del evento, se realizarán } \\
\text { publicaciones de contenido para reforzar el } \\
\text { conocimiento adquirido de la filosofía } \\
\text { corporativa en los colaboradores de acuerdo } \\
\text { a la programación de contenidos por los } \\
\text { distintos canales (tratada en la estrategia 2). }\end{array}$ \\
\hline $\begin{array}{l}\text { Realiza una trivia de filosofía } \\
\text { corporativa }\end{array}$ & $\begin{array}{l}\text { Realizar una trivia que permita reconocer } \\
\text { los conocimientos aprendidos de cada de la } \\
\text { trivia corporativa. }\end{array}$ \\
\hline
\end{tabular}


Estrategia 2: Potenciar los canales de comunicación internos de Selva \& Salud para que sean participativos y efectivos.

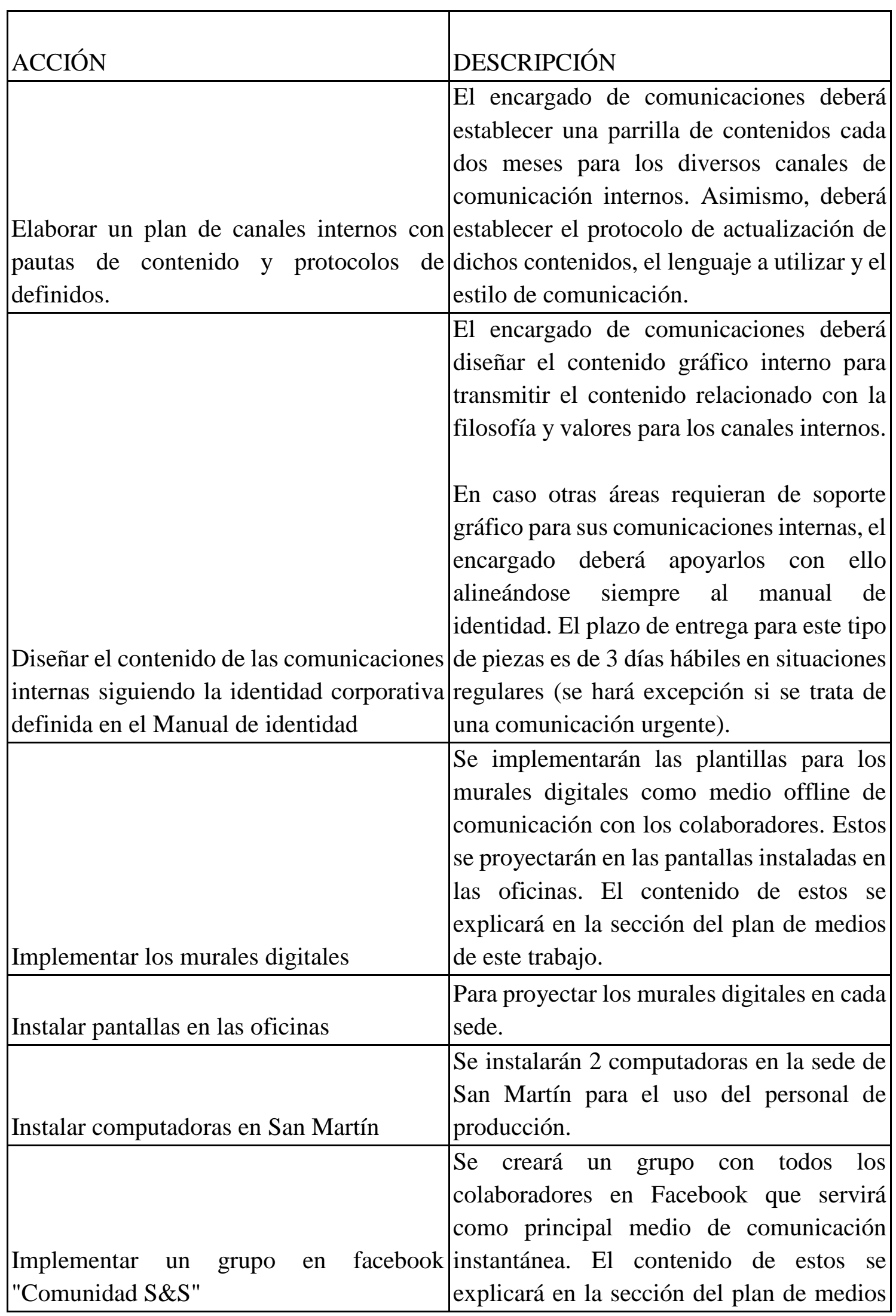




\begin{tabular}{|l|l|}
\hline Comprar celular corporativo & $\begin{array}{l}\text { de este trabajo. Se establecerán normas de } \\
\text { convivencia en el grupo. }\end{array}$ \\
\hline Difundir el grupo en facebook & $\begin{array}{l}\text { Se adquirirá un equipo celular para ser } \\
\text { utilizado por el área de Comercial y } \\
\text { Marketing desde Lima. }\end{array}$ \\
\hline $\begin{array}{l}\text { Implementar grupo en Whatsapp "Selva } \\
\text { Salud contigo" }\end{array}$ & $\begin{array}{l}\text { Una vez creado, se enviará a los } \\
\text { colaboradores un correo con el enlace para } \\
\text { unirse al grupo y se difundirá a través de los } \\
\text { murales digitales. }\end{array}$ \\
\hline $\begin{array}{l}\text { Se creará un grupo en Whatsapp para } \\
\text { comunicaciones cortas y recordatorios. }\end{array}$ \\
\hline Rifundir grupo en Whatsapp & $\begin{array}{l}\text { Una vez creado, se enviará a los } \\
\text { colaboradores un correo con el enlace para } \\
\text { unirse al grupo y se difundirá a través de los } \\
\text { murales digitales. Se establecerán normas } \\
\text { canales de comunicación }\end{array}$ \\
\hline $\begin{array}{l}\text { Una vez implementados los nuevos canales, } \\
\text { se realizará una encuesta al tercer mes desde } \\
\text { su implementación para saber si los } \\
\text { colaboradores están satisfechos y valoran } \\
\text { los canales establecidos, qué oportunidades } \\
\text { de mejora identifican, así como pedir sus } \\
\text { sugerencias sobre contenidos a difundir a } \\
\text { través de ellos. }\end{array}$ \\
\hline
\end{tabular}


Estrategia 3: Transmitir la trayectoria de la empresa mediante el uso del storytelling

\begin{tabular}{|c|c|}
\hline ACCIÓN & DESCRIPCIÓN \\
\hline $\begin{array}{l}\text { Reunirnos con los socios para conocer a } \\
\text { fondo la historia de la empresa }\end{array}$ & $\begin{array}{l}\text { Se concertará una reunión entre el } \\
\text { encargado de comunicaciones y los socios } \\
\text { para entender a fondo cómo se constituyó la } \\
\text { empresa, cuál ha sido su desarrollo en los } \\
\text { últimos } 19 \text { años. }\end{array}$ \\
\hline Realizar el guion del producto audiovisual & $\begin{array}{l}\text { Con el contenido obtenido en la reunión con } \\
\text { los socios, se elaborará el guion del video. }\end{array}$ \\
\hline Realizar el video del storytelling & $\begin{array}{l}\text { A través de un video se contará la historia } \\
\text { de Selva \& Salud, y cómo llegó a ser lo que } \\
\text { es hoy en día. La historia la contarán los } \\
\text { personajes de los } 3 \text { socios (Carlos, Fernanda } \\
\text { y Jorge) y será animado. }\end{array}$ \\
\hline $\begin{array}{l}\text { Presentar el video en el primer desayuno } \\
\text { mensual }\end{array}$ & $\begin{array}{l}\text { Se enviará la invitación al primer desayuno } \\
\text { adjuntando el programa anual de } \\
\text { desayunos. La primera presentación del } \\
\text { video será durante el primer desayuno } \\
\text { “¡Buenos días, Selva \& Salud!”. }\end{array}$ \\
\hline $\begin{array}{l}\text { Dividir el video en pastillas como } \\
\text { introducción en los murales digitales }\end{array}$ & $\begin{array}{l}\text { El video se dividirá en pequeñas partes que } \\
\text { puedan utilizarse en la semblanza de } \\
\text { introducción de los murales digitales. }\end{array}$ \\
\hline
\end{tabular}

Estrategia 4: Formar el comité de "Líderes S\&S"

\begin{tabular}{|l|l|}
\hline ACCIÓN & DESCRIPCIÓN \\
\hline & $\begin{array}{l}\text { El comité de Líderes S\&S serán nuestros } \\
\text { aliados en las comunicaciones internas al } \\
\text { personal. Ellos servirán como voceros de } \\
\text { nuestras comunicaciones, así como canal } \\
\text { directo entre recursos humanos y el } \\
\text { personal, pudiendo transmitir al comité } \\
\text { inquietudes o consultas que el personal } \\
\text { pudiera tener. } \\
\text { Definir con los socios los miembros de } \\
\text { este comité }\end{array}$ \\
\hline $\begin{array}{l}\text { El primer comité será conformado por } \\
\text { colaboradores seleccionados por los socios }\end{array}$ \\
\hline
\end{tabular}




\begin{tabular}{|c|c|}
\hline & $\begin{array}{l}\text { según su nivel de influencia y rendimiento. } \\
\text { Más adelante, se podrán definir por } \\
\text { votación. }\end{array}$ \\
\hline $\begin{array}{l}\text { Establecer una propuesta de plan de } \\
\text { anual y la presentación }\end{array}$ & $\begin{array}{l}\text { En base a las actividades y campañas de } \\
\text { comunicación en el año, se establecerá un } \\
\text { plan de trabajo de un año de duración. Este } \\
\text { se validará con los socios antes de su } \\
\text { difusión con el comité. Además, se realizará } \\
\text { una presentación de alto impacto donde se } \\
\text { compartirá el plan. }\end{array}$ \\
\hline $\begin{array}{l}\text { Convocar a los miembros a la primera } \\
\text { reunión }\end{array}$ & $\begin{array}{l}\text { Se invitará a los miembros seleccionados } \\
\text { por los socios a través de un correo. }\end{array}$ \\
\hline $\begin{array}{l}\text { Validar el plan de trabajo con los } \\
\text { miembros }\end{array}$ & $\begin{array}{l}\text { En la primera reunión, se expondrá el plan } \\
\text { de trabajo y se aprobará con los miembros. }\end{array}$ \\
\hline $\begin{array}{l}\text { Invitarlos a ser voceros de la filosofía } \\
\text { corporativa }\end{array}$ & $\begin{array}{l}\text { Se explicará el rol que tienen como } \\
\text { miembros del comité Líderes } S \& S \text {. }\end{array}$ \\
\hline $\begin{array}{l}\text { Comunicar los miembros del comité a los } \\
\text { colaboradores }\end{array}$ & $\begin{array}{l}\text { En el desayuno "Buenos días, Selva \& } \\
\text { Salud" más próximo, se comunicará al } \\
\text { personal quiénes son los miembros del } \\
\text { comité. Esta comunicación se rebotará en } \\
\text { los murales digitales. }\end{array}$ \\
\hline Tener reuniones periódicas & $\begin{array}{l}\text { A lo largo del año, se programarán } 3 \\
\text { reuniones adicionales para seguir con el } \\
\text { plan de trabajo establecido. }\end{array}$ \\
\hline
\end{tabular}

Objetivo específico 2: Interiorizar los valores corporativa en su aplicación diaria a través de la campaña "Nuestros valores S\&S".

Estrategia 1: Conocer y vivenciar los valores corporativos de manera cercana

\begin{tabular}{|l|l|}
\hline ACCIÓN & \begin{tabular}{l} 
DESCRIPCIÓN \\
\hline
\end{tabular} \\
$\begin{array}{l}\text { La campaña "Nuestros valores S\&S” busca } \\
\text { acompañar durante todo el plan anual de } \\
\text { Remunicación interna a los colaboradores para } \\
\text { el correcto aprendizaje y aplicación de los } \\
\text { valores corporativos. }\end{array}$ \\
"Nuestros valores S\&S" la campaña & $\begin{array}{l}\text { pe esta forma, los cinco valores serán } \\
\text { trabajados en módulos por } 10 \text { meses (2 meses }\end{array}$ \\
\hline
\end{tabular}




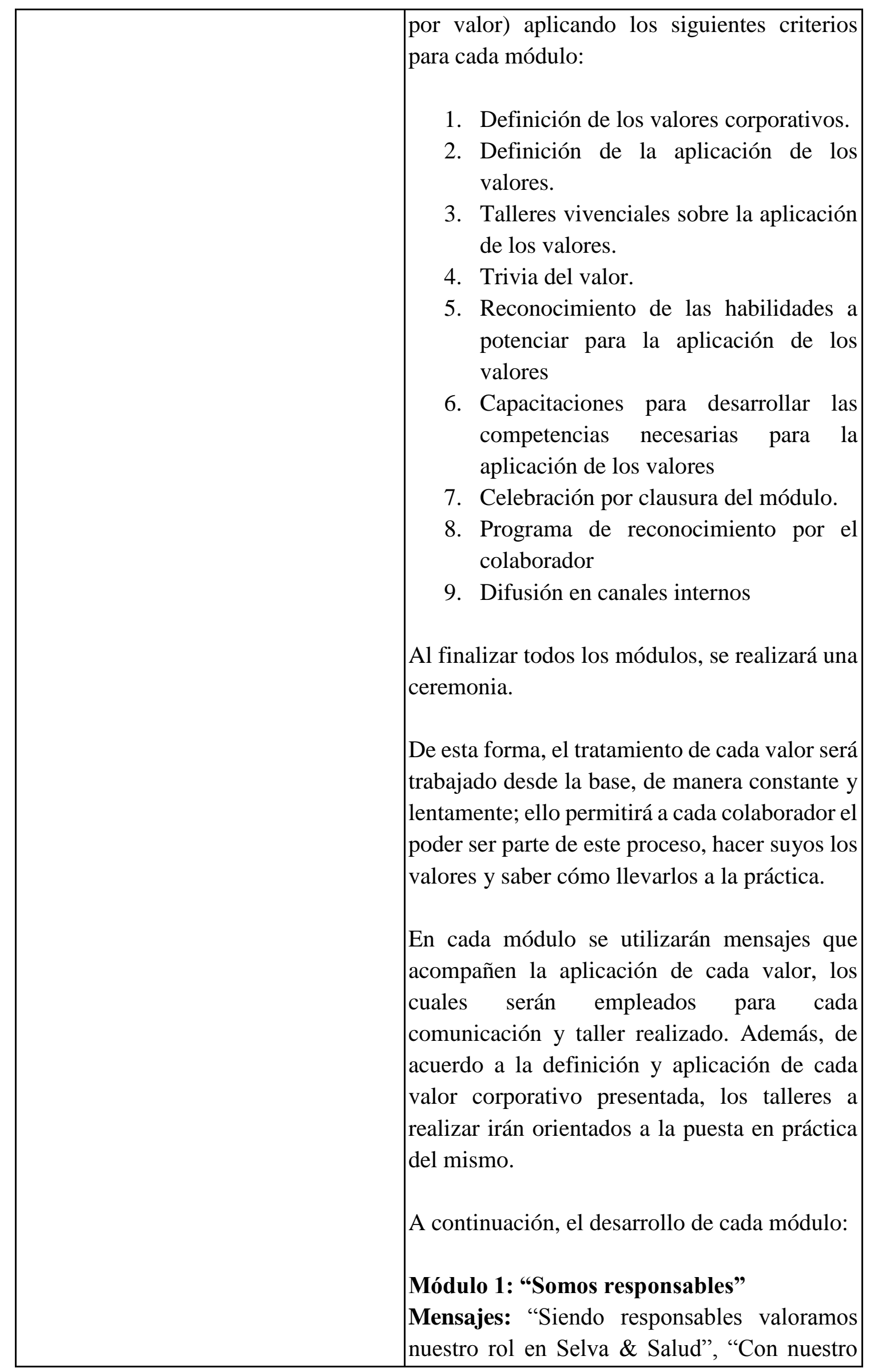




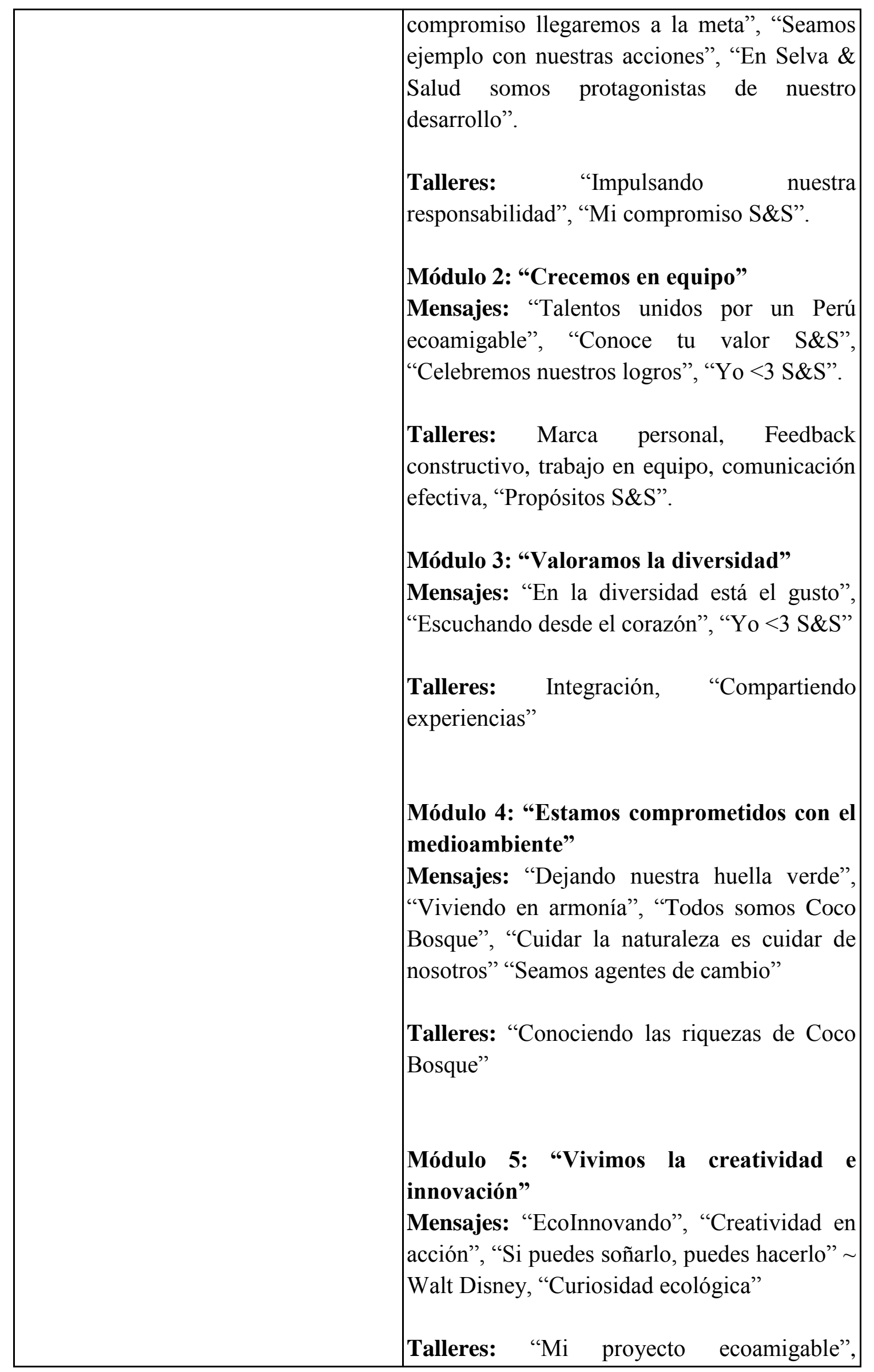




\begin{tabular}{|c|c|}
\hline & Metodologías ágiles y creativas. \\
\hline $\begin{array}{l}\text { Crear los } 3 \text { personajes que representen } \\
\text { los valores corporativos }\end{array}$ & $\begin{array}{l}\text { Dado que los socios de Selva \& Salud son la } \\
\text { esencia de la marca, se crearán } 3 \text { personajes } \\
\text { animados, cada uno representando a un socio. } \\
\text { Estos personajes presentarán características } \\
\text { físicas de los socios y se identificarán con los } \\
\text { valores corporativos. Estos son: } \\
\text { - Somos responsables } \\
\text { - Crecemos en equipo } \\
\text { - Valoramos la diversidad } \\
\text { - Estamos comprometidos con el } \\
\text { medioambiente } \\
\text { - Vivimos la creatividad e innovación } \\
\text { En el caso del primer socio, llamado Carlos, se } \\
\text { alineará con el valor de responsabilidad y el } \\
\text { compromiso con el medioambiente. Carlos es } \\
\text { uno de los socios que vive en San Martín. Su } \\
\text { personaje refleja la calidad de toda la cadena } \\
\text { del aceite de coco sumado a una producción } \\
\text { innovación. La importancia de continuar } \\
\text { sostenible para las comunidades productoras. } \\
\text { En el caso de Fernanda, la segunda socia que } \\
\text { también vive en San Martín, se vinculará con el } \\
\text { crecimiento en equipo y la diversidad. Con ella } \\
\text { se busca reflejar la importancia de mantener } \\
\text { una conexión entre la sede de San Martín y la } \\
\text { de Lima, reconociendo que todos los } \\
\text { colaboradores son importantes en su rol. } \\
\text { Asimismo, la filosofía de trabajar en equipo no } \\
\text { solamente porque el día a día lo requiere, sino } \\
\text { en la concientización de un crecimiento } \\
\text { conjunto donde se respete y se busque ser } \\
\text { empático con las necesidades, creencias, estilos } \\
\text { de dida, compañero de San Martín y de } \\
\text { anar }\end{array}$ \\
\hline
\end{tabular}




\begin{tabular}{|c|c|}
\hline & $\begin{array}{l}\text { mejorando en el producto y atención al cliente, } \\
\text { el gestionar relaciones interpersonales que } \\
\text { aperturen nuevos caminos de crecimiento, la } \\
\text { aplicación de la tecnología en los diversos } \\
\text { procesos de producción, distribución, atención } \\
\text { y comunicación, así como el diálogo y } \\
\text { participación continua de la marca con el } \\
\text { cliente y colaborador, serán los aspectos que lo } \\
\text { representan. }\end{array}$ \\
\hline $\begin{array}{l}\text { Hacer un video de presentación para los } \\
3 \text { personajes }\end{array}$ & $\begin{array}{l}\text { Los } 3 \text { personajes serán utilizados en una } \\
\text { propuesta audiovisual que refleje la aplicación } \\
\text { de los valores e identificación con los socios. }\end{array}$ \\
\hline Difundir video por canales internos & $\begin{array}{l}\text { El video será compartido en el grupo de } \\
\text { Facebook y enviado por mail a los } \\
\text { colaboradores. }\end{array}$ \\
\hline $\begin{array}{l}\text { Preparar el mural "Viviendo la cultura } \\
\text { Selva \& Salud" }\end{array}$ & $\begin{array}{l}\text { El mural constará del título "Viviendo la } \\
\text { cultura Selva \& Salud", seguido por la misión, } \\
\text { visión, y los nombres de los valores. Estos } \\
\text { últimos estarán ubicados alrededor del logo de } \\
\text { la empresa. Mientras se vaya completando cada } \\
\text { módulo, se irá colocando el ícono } \\
\text { correspondiente de cada valor impreso en vinil. } \\
\text { De esta manera, al finalizar los cinco módulos } \\
\text { se tendrá la imagen completa. }\end{array}$ \\
\hline $\begin{array}{l}\text { Elaborar una cartilla general de la } \\
\text { aplicación del valor para la cartilla } \\
\text { "Cultura S\&S a la mano" }\end{array}$ & $\begin{array}{l}\text { Elaborar una cartilla que aplique de manera } \\
\text { general el valor corporativo. } \\
\text { Se colocará en los murales digitales y el } \\
\text { Facebook Interno. Además, se colocará en } \\
\text { físico en la cartilla "Cultura S\&S a la mano" } \\
\text { que se les entregó en el evento de lanzamiento } \\
\text { de filosofía corporativa "Somos Selva \& } \\
\text { Salud". }\end{array}$ \\
\hline $\begin{array}{l}\text { Elaborar una cartilla por área con la } \\
\text { aplicación de los valores para la cartilla } \\
\text { "Cultura S\&S a la mano" }\end{array}$ & $\begin{array}{l}\text { Invitar a que cada área pueda armar su propia } \\
\text { lista de aplicación del valor de manera más } \\
\text { específica de acuerdo al desarrollo y las } \\
\text { necesidades de su día a día. } \\
\text { Luego de ello, se recogerán las listas realizadas } \\
\text { y se utilizara una misma plantilla para mantener } \\
\text { una imagen corporativa alineada. Esta plantilla } \\
\text { se colocará en cada área o espacio de trabajo, }\end{array}$ \\
\hline
\end{tabular}




\begin{tabular}{|c|c|}
\hline & $\begin{array}{l}\text { así como en la cartilla "Cultura S\&S a la } \\
\text { mano". }\end{array}$ \\
\hline Hacer un banner para cada personaje & $\begin{array}{l}\text { Cada personaje contará con un banner donde se } \\
\text { colocará las aplicaciones generales del valor. } \\
\text { De esta forma, los colaboradores podrán verlos } \\
\text { constantemente y tenerlos presentes. } \\
\begin{array}{l}\text { Los banners serán colocados en sitios } \\
\text { estratégicos }\end{array}\end{array}$ \\
\hline Recordatorio de talleres & $\begin{array}{l}\text { Los talleres serán agendados en el calendar de } \\
\text { los colaboradores y colocados en los murales } \\
\text { digitales para su recordación. }\end{array}$ \\
\hline $\begin{array}{l}\text { Realizar un taller vivencial sobre el } \\
\text { valor correspondiente }\end{array}$ & $\begin{array}{l}\text { En los siguientes talleres se busca aplicar los } \\
\text { contenidos explicados para el valor } \\
\text { correspondiente de manera creativa y lúdica, de } \\
\text { modo que se lleven a la práctica mediante } \\
\text { actividades y proyectos que agreguen valor a la } \\
\text { organización, mientras el colaborador vive el } \\
\text { valor de manera más cercana. } \\
\text { Los talleres se programarán para los días } \\
\text { viernes con duración de } 1 \text { a } 2 \text { horas, con previa } \\
\text { comunicación. }\end{array}$ \\
\hline $\begin{array}{l}\text { Realizar encuesta de aplicación y } \\
\text { satisfacción }\end{array}$ & $\begin{array}{l}\text { Al finalizar el taller, se enviará vía correo una } \\
\text { encuesta de aplicación y satisfacción que será } \\
\text { utilizada como insumo para la siguiente } \\
\text { estrategia. }\end{array}$ \\
\hline $\begin{array}{l}\text { Realizar una compartir celebrando la } \\
\text { clausura de cada módulo }\end{array}$ & $\begin{array}{l}\text { Al finalizar cada módulo se realizará un } \\
\text { compartir en el desayuno "Buenos días, S\&S", } \\
\text { donde se entregará a cada colaborador un pin } \\
\text { con la imagen del valor, celebrando así la } \\
\text { clausura del módulo. } \\
\text { Además, se procederá a colocar el vinil del } \\
\text { valor en el mural. }\end{array}$ \\
\hline Difundir el taller en canales internos & $\begin{array}{l}\text { Se colocarán fotografías de la clausura del } \\
\text { módulo en el canal interno de Facebook y } \\
\text { mediante correo corporativo. }\end{array}$ \\
\hline $\begin{array}{l}\text { Realizar una ceremonia al completar } \\
\text { todos los valores corporativos }\end{array}$ & $\begin{array}{l}\text { Al completar el aprendizaje, aplicación y } \\
\text { capacitación de los cinco valores, se procederá } \\
\text { a realizar una ceremonia reconociendo el } \\
\text { compromiso, esfuerzo y aporte de cada }\end{array}$ \\
\hline
\end{tabular}




\begin{tabular}{|l|l|l|}
\hline & $\begin{array}{l}\text { colaborador para completar cada módulo. } \\
\text { Además, se les entregará el pin del último valor } \\
\text { y se colocará el vinil final. }\end{array}$ \\
\hline $\begin{array}{l}\text { Publicación de un video sobre la celebración de } \\
\text { la clausura que estará acompañado de la } \\
\text { descripción de la campaña, testimonios de los } \\
\text { colaboradores y las experiencias compartidas } \\
\text { en la ceremonia. }\end{array}$ \\
$\begin{array}{l}\text { Realizar una publicación en redes } \\
\text { internas y externas sobre la campaña de } \\
\text { valores }\end{array}$ & $\begin{array}{l}\text { El video será colocado en el grupo de Facebook } \\
\text { interno, enviado en mailing por correo } \\
\text { corporativo, fanpage e Instagram. }\end{array}$ \\
\hline
\end{tabular}

Estrategia 2: Capacitar a los colaboradores en habilidades alineadas a nuestros valores

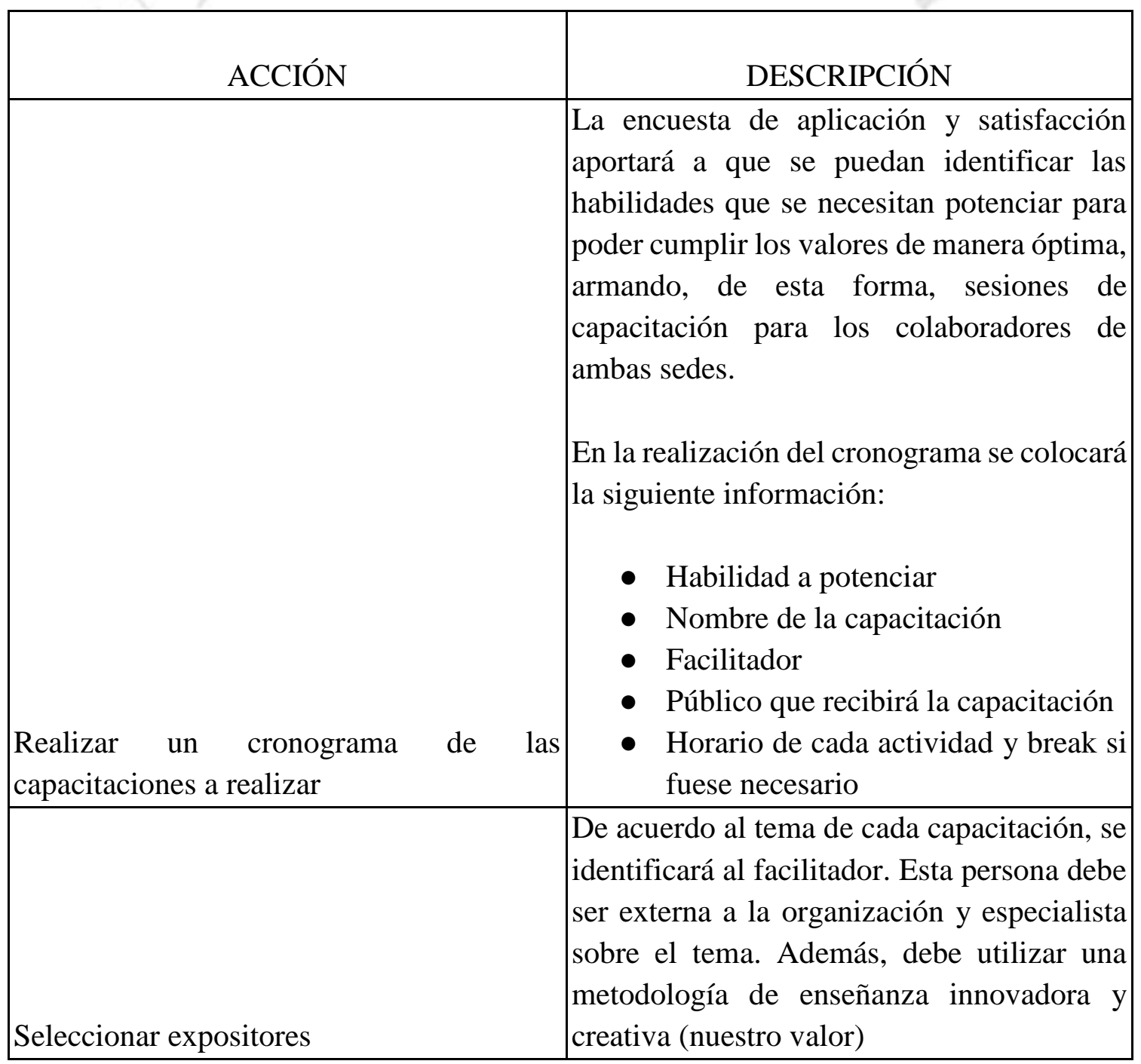




\begin{tabular}{|c|c|}
\hline $\begin{array}{l}\text { Diseñar un cuestionario de intereses y } \\
\text { expectativas pre capacitaciones }\end{array}$ & $\begin{array}{l}\text { Diseñar un cuestionario que permita } \\
\text { identificar los intereses y expectativas de los } \\
\text { colaboradores para la sesión. Ello permitirá } \\
\text { brindarle una guía al facilitador para } \\
\text { comunicar contenido relevante alineado a } \\
\text { las necesidades de los colaboradores, a los } \\
\text { valores y a los objetivos de la organización. }\end{array}$ \\
\hline Elaborar el contenido de las presentaciones & $\begin{array}{l}\text { Las presentaciones serán trabajadas en } \\
\text { conjunto con el expositor, aplicando el estilo } \\
\text { Selva \& Salud y colocando el logo de la } \\
\text { empresa. }\end{array}$ \\
\hline Diseñar una cartilla de enseñanzas & $\begin{array}{l}\text { Luego de la capacitación, se difundirá una } \\
\text { cartilla en los canales internos con los } \\
\text { principales hallazgos obtenidos de la } \\
\text { capacitación, así como preguntas de } \\
\text { reflexión sobre el tema. }\end{array}$ \\
\hline Difundir las capacitaciones & $\begin{array}{l}\text { Se colocarán fotografías de las } \\
\text { capacitaciones en los canales internos como } \\
\text { el Facebook y un mailing al correo } \\
\text { corporativo. }\end{array}$ \\
\hline Encuesta final de capacitaciones & $\begin{array}{l}\text { Al finalizar las sesiones se llevará a cabo una } \\
\text { encuesta para reconocer el nivel de } \\
\text { satisfacción de cada colaborador, así como } \\
\text { nuevos temas para aplicar más adelante. }\end{array}$ \\
\hline & $\begin{array}{l}\text { Realizar una trivia que permita reconocer los } \\
\text { conocimientos aprendidos de cada valor por }\end{array}$ \\
\hline Realizar una trivia según el valor abordado & los colaboradores y los puntos de mejora. \\
\hline & $\begin{array}{l}\text { Trabajar por áreas los puntos de mejora para } \\
\text { mantener a los colaboradores en un proceso } \\
\text { de mejora continua. }\end{array}$ \\
\hline $\begin{array}{l}\text { Abordar puntos de } \\
\text { identificados en la trivia }\end{array}$ & $\begin{array}{l}\text { Cada área deberá realizar un documento que } \\
\text { indique los puntos de reforzamiento, } \\
\text { acciones para la mejora continua, plazos y } \\
\text { responsables del área. }\end{array}$ \\
\hline
\end{tabular}


Estrategia 3: Programa de reconocimiento

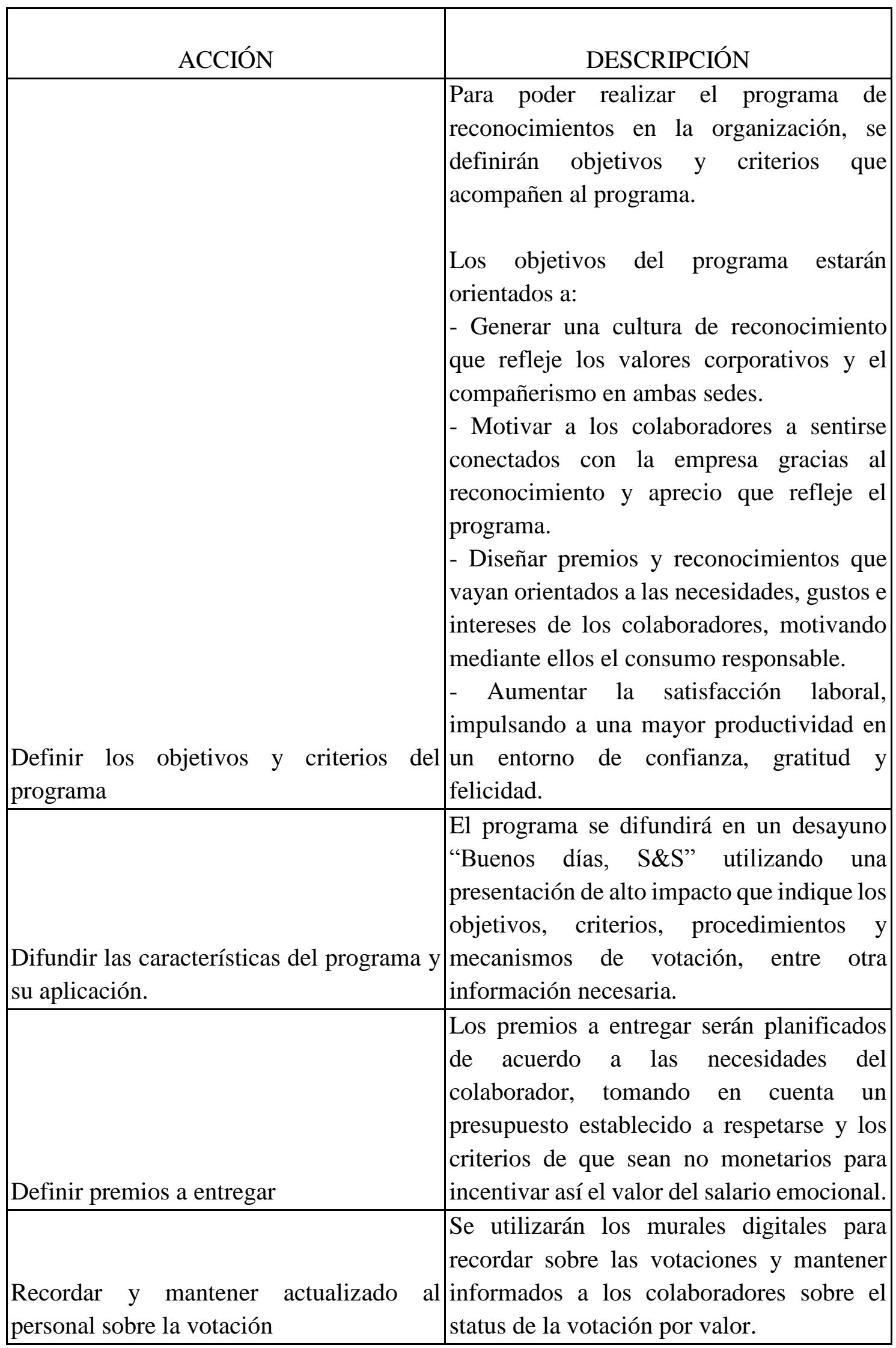




\begin{tabular}{|c|c|}
\hline & $\begin{array}{l}\text { Se utilizará el grupo de Facebook } \\
\text { "Comunidad S\&S" para difundir el } \\
\text { mecanismo de votación. } \\
\text { Para ello se empleará la opción de votación } \\
\text { de la red social donde se colocarán } \\
\text { preguntas relacionadas a la aplicación de los } \\
\text { valores "S\&S". Para cada valor se realizará } \\
1 \text { votación. } \\
\text { Ambas sedes contarán con } 2 \text { semanas para } \\
\text { elegir al candidato que mejor aplique la } \\
\text { pregunta. } \\
\text { De esta forma, se irán realizando diversas } \\
\text { preguntas que los colaboradores deberán ir } \\
\text { respondiendo para elegir finalmente a los } \\
\text { más votados. }\end{array}$ \\
\hline Premiar a los más votados por cada valor & $\begin{array}{l}\text { En el compartir de cierre de cada módulo de } \\
\text { valor, los socios premiarán a los más } \\
\text { votados. }\end{array}$ \\
\hline $\begin{array}{l}\text { Realizar una publicación en redes internas } \\
\text { y externas sobre el programa de } \\
\text { reconocimiento. }\end{array}$ & $\begin{array}{l}\text { Se realizará una publicación con diversas } \\
\text { fotos de la premiación. El copy comunicará } \\
\text { sobre el programa y los más votados. } \\
\text { Para ello, se utilizará el grupo de Facebook } \\
\text { de la comunidad, Instagram, el fanpage y el } \\
\text { correo corporativo donde se enviará un } \\
\text { mailing con el enlace hacia la publicación. }\end{array}$ \\
\hline
\end{tabular}

Objetivo Específico 3: Relacionar a los colaboradores con la propuesta de valor de Selva \& Salud

Estrategia 1: Difundir los atributos del producto bandera de la empresa (aceite de coco).

\begin{tabular}{|l|l|}
\hline \multicolumn{1}{|c|}{ ACCIÓN } & \multicolumn{1}{|c|}{ DESCRIPCIÓN } \\
\hline Elaborar una guía informativa del producto & $\begin{array}{l}\text { La guía del producto incluirá el origen del } \\
\text { mismo, atributos, proceso de producción, } \\
\text { valores diferenciales a comunicar al cliente, } \\
\text { tipo de cliente al que nos dirigimos y puntos } \\
\text { de venta. }\end{array}$ \\
$\begin{array}{l}\text { Esta guía se enviará por correo corporativo. } \\
\text { Además, se imprimirá y colocará en un }\end{array}$ \\
\hline
\end{tabular}




\begin{tabular}{|c|c|}
\hline & $\begin{array}{l}\text { pioner para mantener su calidad y que } \\
\text { pueda ser utilizada como material de } \\
\text { consulta o presentación. }\end{array}$ \\
\hline $\begin{array}{l}\text { Taller de formación "Valorando y } \\
\text { compartiendo mi producto" }\end{array}$ & $\begin{array}{l}\text { En este taller se busca comunicar sobre el } \\
\text { producto, sus beneficios y ventajas, } \\
\text { compartiendo así experiencias y generando } \\
\text { una identificación y comunicación alineada } \\
\text { sobre el mismo. Para ello, se realizará una } \\
\text { presentación y se motivará a un } \\
\text { conversatorio entre los asistentes. } \\
\text { El taller se realizará un viernes en horario } \\
\text { de oficina con duración de } 1 \text { a } 2 \text { horas, } \\
\text { coordinación previa. }\end{array}$ \\
\hline $\begin{array}{l}\text { Reconocer a los colaboradores que se } \\
\text { embajadores de la marca en sus redes }\end{array}$ & $\begin{array}{l}\text { Reconocer a los colaboradores que más han } \\
\text { compartido sobre la marca y sus } \\
\text { experiencias con la misma en sus redes. El } \\
\text { contenido compartido a tomar en cuenta } \\
\text { para el reconocimiento es: } \\
\text { - Publicaciones sobre el producto } \\
\text { - Publicaciones utilizando el } \\
\text { producto } \\
\text { - Compartir en sus redes las } \\
\text { publicaciones realizadas en el } \\
\text { fanpage o Instagram de Selva \& } \\
\text { Salud } \\
\text { Publicaciones sobre talleres, } \\
\text { capacitaciones y reconocimientos } \\
\text { recibidos } \\
\text { El reconocimiento se realizará en el } \\
\text { desayuno "Buenos días, S\&S", dando como } \\
\text { premio cupones para restaurantes, cine o un } \\
\text { día libre. }\end{array}$ \\
\hline $\begin{array}{l}\text { Difundir los puntos más resaltantes del } \\
\text { taller de formación }\end{array}$ & $\begin{array}{l}\text { Colocar en una sección del mural digital, } \\
\text { los aspectos más importantes del taller de } \\
\text { formación. }\end{array}$ \\
\hline
\end{tabular}


Estrategia 2: Fomentar que los colaboradores se identifiquen con su rol en el propósito de consumo responsable mediante el programa "¡S\&S en acción!"

\begin{tabular}{|c|c|}
\hline ACCIÓN & DESCRIPCIÓN \\
\hline $\begin{array}{l}\text { Realizar el cronograma de trabajo para las } \\
\text { sesiones a realizar }\end{array}$ & $\begin{array}{l}\text { En la realización del cronograma se } \\
\text { colocará la siguiente información: } \\
\text { - Habilidad a potenciar } \\
\text { - Nombre de la capacitación } \\
\text { - Facilitador } \\
\text { - Público que recibirá la capacitación } \\
\text { - Horario de cada actividad y break si } \\
\text { fuese necesario } \\
\text { El cronograma será realizado en una } \\
\text { reunión de trabajo. Se llevarán a cabo } 3 \\
\text { sesiones. }\end{array}$ \\
\hline Contratar a un facilitador para el programa & $\begin{array}{l}\text { De acuerdo al tema de cada sesión se } \\
\text { identificará al facilitador. Esta persona debe } \\
\text { ser externa a la organización y especialista } \\
\text { sobre el tema. Además, debe utilizar una } \\
\text { metodología de enseñanza innovadora y } \\
\text { creativa (nuestro valor) }\end{array}$ \\
\hline $\begin{array}{l}\text { Enviar una comunicación interna sobre el } \\
\text { lanzamiento del programa }\end{array}$ & $\begin{array}{l}\text { La pieza contendrá la información sobre } \\
\text { cada sesión y el nombre del programa } \\
\text { “iS\&S en acción!”. Además, se motivará a } \\
\text { que los colaboradores puedan potenciar sus } \\
\text { talentos y realizar proyectos juntos que } \\
\text { agreguen valor a la organización. } \\
\text { Será difundida mediante los murales } \\
\text { digitales y el correo corporativo”. }\end{array}$ \\
\hline $\begin{array}{l}\text { En el programa, dividir a los colaboradores } \\
\text { en equipos (por áreas y multidisciplinarios) }\end{array}$ & $\begin{array}{l}\text { Al iniciar el programa, cada colaborador } \\
\text { estará reunido por áreas. De esta manera, } \\
\text { podrán encontrar fortalezas y puntos a } \\
\text { mejora, reconociendo insights importantes. } \\
\text { Al terminar la primera sesión, se crearán } \\
\text { equipos multidisciplinarios. } \\
\text { En la segunda sesión, mediante la } \\
\text { aplicación de metodologías ágiles y } \\
\text { creativas, los equipos podrán identificar }\end{array}$ \\
\hline
\end{tabular}




\begin{tabular}{|c|c|}
\hline & $\begin{array}{l}\text { productos o servicios a aplicar en la } \\
\text { organización. } \\
\text { En la tercera sesión, los equipos expondrán } \\
\text { sus proyectos. }\end{array}$ \\
\hline $\begin{array}{l}\text { Difundir las sesiones de trabajo en nuestros } \\
\text { canales internos }\end{array}$ & $\begin{array}{l}\text { Se colocará una publicación con fotografías } \\
\text { del programa. En el copy se contará de qué } \\
\text { se trata y cuáles son sus objetivos en la } \\
\text { aplicación. }\end{array}$ \\
\hline $\begin{array}{l}\text { Presentación de proyectos trabajados por } \\
\text { los equipos }\end{array}$ & $\begin{array}{l}\text { Los equipos expondrán a sus demás } \\
\text { compañeros los proyectos creados. Cada } \\
\text { proyecto debe incluir: } \\
\text { - Entorno, contexto } \\
\text { - Desafío identificado } \\
\text { - Planteamiento a realizar } \\
\text { - Concepto creativo } \\
\text { - Áreas responsables } \\
\text { - Aproximaciones de presupuesto. } \\
\text { Las ideas deben ser compartidas mediante } \\
\text { un speech de impacto. Además, los } \\
\text { proyectos serán medidos del } 1 \text { al } 10 \text { de } \\
\text { acuerdo a los criterios identificados. }\end{array}$ \\
\hline $\begin{array}{l}\text { Realizar un video resumen de las sesiones } \\
\text { con sus principales hallazgos }\end{array}$ & $\begin{array}{l}\text { Se compartirá un video resumen sobre las } \\
\text { tres sesiones, agradeciendo a los } \\
\text { colaboradores por su participación. } \\
\text { Cada proyecto será visto con la Gerencia } \\
\text { para determinar su aplicación. }\end{array}$ \\
\hline
\end{tabular}

Estrategia 3: Comprometer a los colaboradores con las comunidades productoras de la selva y el medioambiente.

\begin{tabular}{|l|l|}
\hline \multicolumn{1}{|c|}{ ACCIÓN } & \multicolumn{1}{|c|}{ DESCRIPCIÓN } \\
\hline Formar un equipo con comisiones en San \\
$\begin{array}{l}\text { Martín y en Lima que lleven a cabo el } \\
\text { proyecto "Sembrando Selva \& Salud" }\end{array}$ & $\begin{array}{l}\text { El proyecto "Sembrando Selva \& Salud" } \\
\text { está orientado a buscar el desarrollo } \\
\text { sostenible de las familias de la comunidad } \\
\text { Coco Bosque. La idea es que sea un } \\
\text { proyecto de largo aliento de responsabilidad }\end{array}$ \\
\hline
\end{tabular}




\begin{tabular}{|c|c|}
\hline & $\begin{array}{l}\text { social, que involucre a sus colaboradores } \\
\text { con la comunidad de manera estratégica. En } \\
\text { este primer año, se trabajará la primera fase } \\
\text { del proyecto: la recolección de información } \\
\text { y primer contacto con la comunidad para } \\
\text { tener la materia prima para el desarrollo de } \\
\text { la propuesta de trabajo según las } \\
\text { necesidades de la comunidad. Para ello, se } \\
\text { formará un equipo conformado por una } \\
\text { comisión en Lima y otra en San Martín } \\
\text { quienes liderarán esta primera fase. Ambas } \\
\text { comisiones tendrán un representante por } \\
\text { sede, y deberán tener por lo menos } 5 \\
\text { voluntarios. }\end{array}$ \\
\hline $\begin{array}{l}\text { Convocar a los interesados que deseen } \\
\text { participar en el proyecto. }\end{array}$ & $\begin{array}{l}\text { Se enviará por correo electrónico y se } \\
\text { difundirá por los murales digitales la } \\
\text { convocatoria abierta a ser parte de este } \\
\text { proyecto. En la invitación se pondrán los } \\
\text { objetivos del proyecto, cómo será la } \\
\text { participación y un link de inscripción donde } \\
\text { podrán solicitar su ingreso al proyecto. }\end{array}$ \\
\hline \multirow[t]{2}{*}{$\begin{array}{l}\text { Convocar a las familias interesadas en San } \\
\text { Martín que deseen apoyar en la } \\
\text { investigación y diagnóstico }\end{array}$} & $\begin{array}{l}\text { En San Martín, la comisión de esa sede } \\
\text { comenzará con el reconocimiento de las } \\
\text { familias a las que se acudirá para esta fase } \\
\text { del proyecto. Para ello, se elaborarán unos } \\
\text { volantes físicos informativos del proyecto } \\
\text { que distribuirán durante tres días por las } \\
\text { parcelas pertenecientes a Coco Bosque, y } \\
\text { los dos días restantes irán confirmando e } \\
\text { inscribiendo a los interesados. También se } \\
\text { habilitará un teléfono celular al que la } \\
\text { familia puede llamar para confirmar su } \\
\text { participación. }\end{array}$ \\
\hline & $\begin{array}{l}\text { Para inscribirse, las familias deberán } \\
\text { proveer esta información: } \\
\text { - Nombres y apellidos de miembros } \\
\text { de la familia } \\
\text { - DNI } \\
\text { - Dirección } \\
\text { - Teléfono de contacto }\end{array}$ \\
\hline $\begin{array}{l}\text { Viaje del equipo seleccionado de Lima a } \\
\text { San Martin }\end{array}$ & $\begin{array}{l}\text { La comisión de Lima viajará a San Martín } \\
\text { por tierra. }\end{array}$ \\
\hline
\end{tabular}




\begin{tabular}{|c|c|}
\hline $\begin{array}{l}\text { Recopilación de información en las familias } \\
\text { de San Martìn }\end{array}$ & 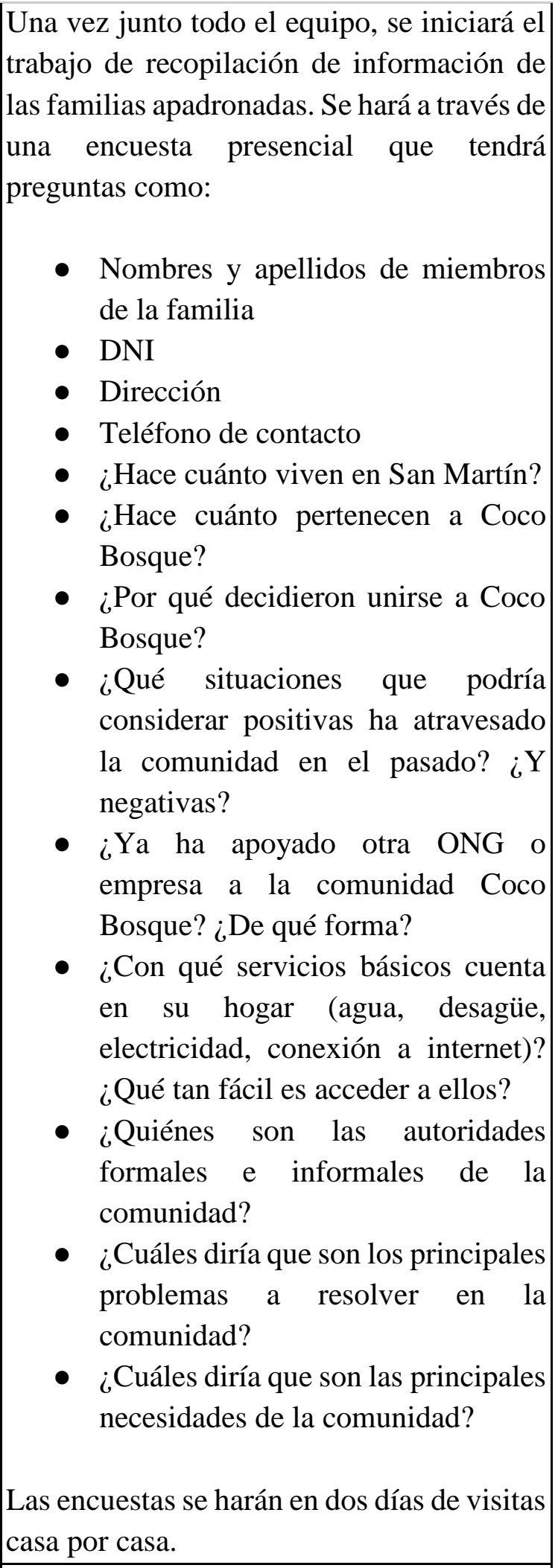 \\
\hline Realizar un compartir con la comunidad & $\begin{array}{l}\text { Una vez finalizada la recopilación de } \\
\text { información, el equipo del proyecto } \\
\text { organizará un compartir informal con las } \\
\text { familias de la comunidad que participaron. } \\
\text { Este se realizará en las instalaciones de }\end{array}$ \\
\hline
\end{tabular}




\begin{tabular}{|c|c|}
\hline & $\begin{array}{l}\text { Coco Bosque. Se servirán bocaditos y } \\
\text { bebidas no alcohólicas sencillas, y } \\
\text { miembros del equipo compartirán sus } \\
\text { apreciaciones sobre su experiencia en esos } \\
\text { días. Se finalizará agradeciendo a las } \\
\text { familias por su colaboración, e indicando } \\
\text { que más adelante vendrán más actividades. }\end{array}$ \\
\hline $\begin{array}{l}\text { Realización de presentación visual sobre } \\
\text { hallazgos }\end{array}$ & $\begin{array}{l}\text { En el siguiente desayuno "Buenos días, } \\
\text { S\&S", los líderes del equipo en Lima y } \\
\text { San Martín presentarán brevemente los } \\
\text { principales hallazgos de las necesidades de } \\
\text { la comunidad que Selva \& Salud podría } \\
\text { ayudar a resolver. }\end{array}$ \\
\hline $\begin{array}{l}\text { Difundir resultados de la primera fase del } \\
\text { proyecto }\end{array}$ & $\begin{array}{l}\text { Estos hallazgos se difundirán por nuestros } \\
\text { canales de comunicación para reforzarlos } \\
\text { en los colaboradores. Asimismo, tanto en } \\
\text { el correo informativo como en la } \\
\text { publicación en el grupo en Facebook se } \\
\text { incluirá un enlace a un buzón de } \\
\text { sugerencias (Google forms) donde se } \\
\text { podrán sugerir ideas para el proyecto. }\end{array}$ \\
\hline $\begin{array}{l}\text { Elaborar un plan de trabajo a partir de los } \\
\text { hallazgos }\end{array}$ & $\begin{array}{l}\text { El equipo continuará trabajando en lo que } \\
\text { queda del año en la propuesta de trabajo } \\
\text { para los siguientes } 4 \text { años. Contarán con la } \\
\text { ayuda del área de Comercial y Marketing. }\end{array}$ \\
\hline
\end{tabular}




\subsection{Plan de comunicación externa}

\subsubsection{Objetivos del plan}

\section{Objetivo general:}

Consolidar el posicionamiento de Selva \& Salud para generar una relación con sus públicos externos (clientes y proveedores)

Objetivo específico 1: Dar a conocer la identidad corporativa de Selva \& Salud hacia sus clientes y proveedores.

Estrategia 1: Difundir la imagen de Selva \& Salud como empresa que fomenta el consumo responsable y cuidado del medioambiente.

\begin{tabular}{|c|c|}
\hline ACCIÓN & DESCRIPCIÓN \\
\hline $\begin{array}{l}\text { Realizar campaña en redes sociales "La } \\
\text { selva en tus manos" }\end{array}$ & $\begin{array}{l}\text { La campaña corresponde a fomentar el } \\
\text { consumo responsable y cuidado del } \\
\text { medioambiente. El consumo responsable } \\
\text { parterá de lo indicado en el propósito de } \\
\text { Selva \& Salud: } \\
\text { ¿Cómo fomentamos un consumo } \\
\text { responsable? } \\
\text { En nuestros clientes: Brindando a } \\
\text { nuestros clientes información } \\
\text { actualizada, accesible y de valor } \\
\text { para que conozcan los beneficios de } \\
\text { consumir productos más } \\
\text { sostenibles y adopten un estilo de } \\
\text { vida saludable y ecoamigable. } \\
\text { De esta manera, la campaña iniciará } \\
\text { con mensajes que inviten a los usuarios a } \\
\text { unirse a la campaña como: } \\
\text { "Viviendo la cultura S\&S, ¿te unes?", "La } \\
\text { selva en tus manos". } \\
\text { Luego, junto al aceite de coco, se realizarán } \\
\text { publicaciones sobre sus beneficios desde el } \\
\text { ámbito alimenticio y de uso. Por otro lado, } \\
\text { se compartirán videos que cuenten el } \\
\text { proceso del aceite de coco, curiosidades de } \\
\text { la selva y sus valores para nuestro producto. } \\
\text { Además, se realizarán videos cortos sobre } \\
\text { productos sostenibles, tips y se compartirán } \\
\text { artículos propios desde la web y ya creados, }\end{array}$ \\
\hline
\end{tabular}




\begin{tabular}{|c|c|}
\hline & $\begin{array}{l}\text { utilizando los mensajes "Dejando nuestra } \\
\text { huella verde", "Cuidar la naturaleza es } \\
\text { cuidar de nosotros" y "Seamos agentes de } \\
\text { cambio". }\end{array}$ \\
\hline Creación de videos institucionales & $\begin{array}{l}\text { Con los siguientes videos se busca } \\
\text { transmitir en la historia de la organización } \\
\text { y su propósito hacia el consumo } \\
\text { responsable y cuidado del medio. }\end{array}$ \\
\hline Difusión de videos institucionales & $\begin{array}{l}\text { Los videos serán difundidos mediante el } \\
\text { fanpage y el Instagram de la empresa, así } \\
\text { como mediante un mailing que se envíe a } \\
\text { los clientes invitándolos a conocernos. }\end{array}$ \\
\hline $\begin{array}{l}\text { Mail sobre nueva imagen y filosofía } \\
\text { empresarial }\end{array}$ & $\begin{array}{l}\text { Junto a los videos institucionales se añadirá } \\
\text { la nueva imagen y filosofía empresarial. }\end{array}$ \\
\hline $\begin{array}{l}\text { Reunión con productores de Coco } \\
\text { Bosque para comunicarles la nueva } \\
\text { filosofía e imagen }\end{array}$ & $\begin{array}{l}\text { En la reunión con Coco Bosque se busca } \\
\text { transmitir nuestra filosofía corporativa e } \\
\text { imagen, invitando a las comunidades a ser } \\
\text { parte de nuestro propósito y reconociendo la } \\
\text { importancia de su rol durante toda la } \\
\text { trayectoria de la empresa. } \\
\text { Además, se busca escuchar sus dudas, } \\
\text { mejoras, ideas y sugerencias frente lo } \\
\text { expuesto. }\end{array}$ \\
\hline $\begin{array}{l}\text { Artículos sobre el consumo } \\
\text { responsable }\end{array}$ & $\begin{array}{l}\text { En nuestra sección "Blog" en la página web } \\
\text { compartiremos notas relacionadas al estilo } \\
\text { de vida saludable, al cuidado del medio } \\
\text { ambiente, a la selva y las comunidades con } \\
\text { las que compartirmos, enseñanzas } \\
\text { aprendidas, entre otros artículos. } \\
\text { Se compartirán los artículos por el fanpage } \\
\text { de la empresa para darles mayor difusión. }\end{array}$ \\
\hline
\end{tabular}


Estrategia 2: Potenciar el rol de los socios como embajadores de la marca

\begin{tabular}{|c|c|}
\hline ACCIÓN & DESCRIPCIÓN \\
\hline $\begin{array}{l}\text { Realizar Instagram Stories e historias } \\
\text { en Facebook en las redes de la empresa }\end{array}$ & $\begin{array}{l}\text { Realizar un cronograma de historias a } \\
\text { publicar para cada red. } \\
\text { Coordinar con los socios sobre las } \\
\text { experiencias que se buscan mostrar en las } \\
\text { historias de ambas redes, así como los } \\
\text { mensajes a incluir y lineamientos de } \\
\text { grabación. Con el objetivo de contar con el } \\
\text { material y poder disponer del mismo, los } \\
\text { socios grabarán videos y luego estos serán } \\
\text { subidos de acuerdo al cronograma indicado. }\end{array}$ \\
\hline $\begin{array}{l}\text { Realizar eventos y talleres donde } \\
\text { participen los socios como expositores }\end{array}$ & $\begin{array}{l}\text { Se realizará un cronograma de talleres y } \\
\text { eventos donde participarán los socios como } \\
\text { expositores. Estos eventos o talleres serán } \\
\text { realizados en la sede de Surquillo y en la } \\
\text { sede de San Martín en un espacio } \\
\text { acondicionado. }\end{array}$ \\
\hline $\begin{array}{l}\text { Coordinar la participación de socios en } \\
\text { diarios versión digital }\end{array}$ & $\begin{array}{l}\text { Coordinar la participación de los socios en } \\
\text { segmentos del diario El Comercio, } \\
\text { relacionados a productos orgánicos, } \\
\text { producción del aceite de coco, comunidades } \\
\text { productoras peruanas, pymes orgánicas, } \\
\text { cuidado del medioambiente, entre otros. } \\
\text { Se buscará que la participación sea en } \\
\text { artículos digitales; versión más utilizad por } \\
\text { nuestro público objetivo. }\end{array}$ \\
\hline $\begin{array}{l}\text { Difundir la aparición de socios en las } \\
\text { redes sociales }\end{array}$ & $\begin{array}{l}\text { Realizar la revisión de la publicación y } \\
\text { compartirla en el fanpage e Instagram de la } \\
\text { empresa. }\end{array}$ \\
\hline
\end{tabular}


Estrategia 3: Implementar piezas y canales de comunicación externa para potenciar el reconocimiento y venta

\begin{tabular}{|c|c|}
\hline ACCIÓN & DESCRIPCIÓN \\
\hline Elaborar flyers del producto & $\begin{array}{l}\text { Creación de flyers que muestren el producto de } \\
\text { manera visual, indicando los beneficios del } \\
\text { mismo y las frases "Cuidando a las personas y } \\
\text { el medioambiente" y "Viviendo la cultura } \\
\text { Selva \& Salud". } \\
\text { Estos flyers serán utilizados en los puntos de } \\
\text { venta y recojo de nuestro producto. }\end{array}$ \\
\hline $\begin{array}{l}\text { Banners corporativos con la nueva } \\
\text { imagen y el proceso de producción }\end{array}$ & $\begin{array}{l}\text { Realizar banners que contengan el logo de } \\
\text { Selva \& Salud, tipografía y colores } \\
\text { corporativos, así como el proceso de } \\
\text { producción presentado de manera visual y } \\
\text { atractiva para el cliente. }\end{array}$ \\
\hline $\begin{array}{l}\text { Potenciar la línea telefónica de } \\
\text { contacto al cliente "Contacto Selva \& } \\
\text { Salud" }\end{array}$ & $\begin{array}{l}\text { La línea telefónica es un canal existente, por lo } \\
\text { que buscamos aprovechar su valor y aporte } \\
\text { para los clientes. } \\
\text { Para ello, se comunicará en nuestras redes y } \\
\text { capacitará a los encargadores de la línea en } \\
\text { atención al cliente y reconocer que conozcan el } \\
\text { producto, venta, usos y beneficios para } \\
\text { responder todas las dudas del cliente de manera } \\
\text { clara y amical. }\end{array}$ \\
\hline
\end{tabular}

Objetivo Específico 2: Fortalecer la relación de Selva \& Salud con su público externo

Estrategia 1: Generar experiencias positivas de la marca para fidelizar a los clientes

\begin{tabular}{|c|l|}
\hline ACCIÓN & \multicolumn{1}{|c|}{ DESCRIPCIÓN } \\
\hline Generar base de datos de clientes & $\begin{array}{l}\text { Para la generación de la base de datos se } \\
\text { aprovechará la recurrencia del público en las } \\
\text { bioferias y en la tienda de Surquillo para } \\
\text { obtener los datos de los clientes. }\end{array}$ \\
\hline Recompensar a los clientes más fieles & $\begin{array}{l}\text { Los clientes asiduos serán recompensados } \\
\text { con merchandising, productos de la empresa }\end{array}$ \\
\hline
\end{tabular}




\begin{tabular}{|c|c|}
\hline & $\begin{array}{l}\text { y de las alianzas estratégicas. Con ello se } \\
\text { busca agradecerles por su continuidad, } \\
\text { mantenerlos fidelizados y que puedan seguir } \\
\text { recomendando el producto a sus conocidos. }\end{array}$ \\
\hline $\begin{array}{l}\text { Invitar a los clientes a eventos } \\
\text { diversos }\end{array}$ & $\begin{array}{l}\text { Con el objetivo de poder mantener una } \\
\text { relación con los clientes y captar nuevos, se } \\
\text { realizarán diversos eventos para vivir la } \\
\text { cultura Selva \& Salud y sumar experiencias } \\
\text { relacionadas de la marca. } \\
\text { Al finalizar el evento, se comunicará a los } \\
\text { participantes sobre nuestras redes sociales y } \\
\text { la posibilidad de estar en nuestra base para } \\
\text { recibir información de Selva \& Salud. }\end{array}$ \\
\hline $\begin{array}{l}\text { Compartir en redes sociales los } \\
\text { testimonios de los clientes satisfechos } \\
\text { y el uso que le dan al producto }\end{array}$ & $\begin{array}{l}\text { Los testimonios representan las experiencias } \\
\text { positivas de nuestros clientes. Su punto de } \\
\text { vista frente a los productos y el uso de estos } \\
\text { nos dará respaldo y atraerán a nuevos } \\
\text { clientes. } \\
\text { Los testimonios se colocarán en fanpage e } \\
\text { Instagram como publicación o video. }\end{array}$ \\
\hline $\begin{array}{l}\text { Realizar sorteos y promociones en } \\
\text { redes }\end{array}$ & $\begin{array}{l}\text { Los sorteos y promociones atraerán a } \\
\text { nuevos clientes y serán una posibilidad para } \\
\text { probar los productos e incrementar así la } \\
\text { demanda. } \\
\text { Los sorteos y promociones serán realizados } \\
\text { en nuestras redes. Las publicaciones irán } \\
\text { variando de red social para generar tráfico } \\
\text { entre redes. Los productos o servicios a } \\
\text { sortear y promociones serán tanto de Selva } \\
\& \text { Salud, como de las alianzas estratégicas a } \\
\text { realizar. } \\
\text { En el caso del sorteo, se pedirá al ganador o } \\
\text { ganadora que se tome una foto con el } \\
\text { producto o realice una historia en sus redes } \\
\text { para poder utilizar el material. }\end{array}$ \\
\hline
\end{tabular}


Estrategia 2: Establecer alianzas estratégicas con organizaciones y personas relacionadas al consumo responsable

\begin{tabular}{|c|c|}
\hline ACCIÓN & DESCRIPCIÓN \\
\hline $\begin{array}{l}\text { Identificar aliados potenciales en las } \\
\text { bioferias }\end{array}$ & $\begin{array}{l}\text { Para poder identificar a los aliados potenciales } \\
\text { se realizará un benchmark de las empresas que } \\
\text { venden sus productos en la biofería, así como un } \\
\text { proceso de observación. Estos productos deben } \\
\text { ser complementarios al aceite de coco y } \\
\text { mantener cierta alineación con la filosofía, } \\
\text { formas de venta y atención que Selva \& Salud. } \\
\text { De esta manera se creatán alianzas novedosas y } \\
\text { atractivdas para las necesidades del cliente y de } \\
\text { ambas empresas. }\end{array}$ \\
\hline $\begin{array}{l}\text { Abordar a los aliados estratégicos } \\
\text { para definir expectativas comunes }\end{array}$ & $\begin{array}{l}\text { Se conversará con los aliados identificados } \\
\text { para reconocer formas de trabajar en conjunto } \\
\text { y encontrar objetivos comunes para llevar a } \\
\text { cabo la alianza de manera exitosa. }\end{array}$ \\
\hline Realizar actividades en conjunto & $\begin{array}{l}\text { Frente los objetivos comunes planteados, se } \\
\text { realizarán actividades en conjunto que } \\
\text { muestren lo mejor de cada marca y sus } \\
\text { productos. De esta forma, se busca ampliar el } \\
\text { número de clientes al que llega el producto, } \\
\text { atrayendo a potenciales. } \\
\text { Las actividades serán colocadas en un } \\
\text { calendario y se buscará que estén alineadas a } \\
\text { fechas donde el consumidor tienda a consumir } \\
\text { más o regalar (Ej. Día de la madre, Fiestas } \\
\text { patrias, Navidad). }\end{array}$ \\
\hline $\begin{array}{l}\text { Publicar el producto del negocio } \\
\text { aliado en nuestras redes sociales }\end{array}$ & $\begin{array}{l}\text { La difusión de los productos o actividades en } \\
\text { conjunto se realizarán en el fanpage e } \\
\text { Instagram de Selva \& Salud. } \\
\text { En el copy se comunicará el objetivo de la } \\
\text { alianza, utilizando mensajes como "Sumando } \\
\text { nuestras fortalezas para un Perú que viva el } \\
\text { consumo responsable hacia un estilo de vida } \\
\text { ecoamigable" y "Dando a conocer nuestro } \\
\text { valor". }\end{array}$ \\
\hline
\end{tabular}


Objetivo específico 3: Construir un ecosistema digital sólido que permita el posicionamiento de Selva \& Salud en internet

Estrategia 1: Implementar la página web corporativa de Selva \& Salud

\begin{tabular}{|c|c|}
\hline ACCIÓN & DESCRIPCIÓN \\
\hline $\begin{array}{l}\text { Identificar y recopilar la información } \\
\text { necesaria para colocarla en la página web }\end{array}$ & $\begin{array}{l}\text { Para realizar esta acción, el encargado de } \\
\text { comunicaciones se reunirá con las áreas } \\
\text { involucradas en la producción de } \\
\text { contenido según el siguiente esquema: } \\
\text { 1. Inicio: Comercial y Marketing. } \\
\text { 2. Nosotros: Socios y Comercial y } \\
\text { Marketing. } \\
\text { 3. Productos: Miembros del área de } \\
\text { producción y ventas para definir } \\
\text { el contenido relacionado al } \\
\text { producto. comunidad: } \\
\text { 4. Nuestra la la } \\
\text { Representantes de Coco Bosque } \\
\text { para reunir información de la } \\
\text { comunidad. Representantes de la } \\
\text { municipalidad de los distritos } \\
\text { donde se desenvuelve la empresa. } \\
\text { 5. Blog: Artículos producidos por } \\
\text { los socios y el encargado de } \\
\text { comunicaciones. } \\
\text { 6. Contacto: Tendrá la información } \\
\text { de contacto (teléfono, dirección y } \\
\text { correo), así como un formulario } \\
\text { para hacer pedidos o consultas. } \\
\text { El contenido final será revisado por } \\
\text { Comercial \& Marketing para garantizar } \\
\text { cumpla con el estilo de } \\
\text { comunicación definido por la empresa. } \\
\text { Luego, se presentará en una reunión final } \\
\text { con los socios antes del envío a la agencia } \\
\text { digital. }\end{array}$ \\
\hline Planificación de la página web & $\begin{array}{l}\text { La página web se trabajará de la mano } \\
\text { con una agencia digital en cada una de } \\
\text { sus etapas. Previo a la planificación, se } \\
\text { compartirá un brief desarrollado a partir }\end{array}$ \\
\hline
\end{tabular}




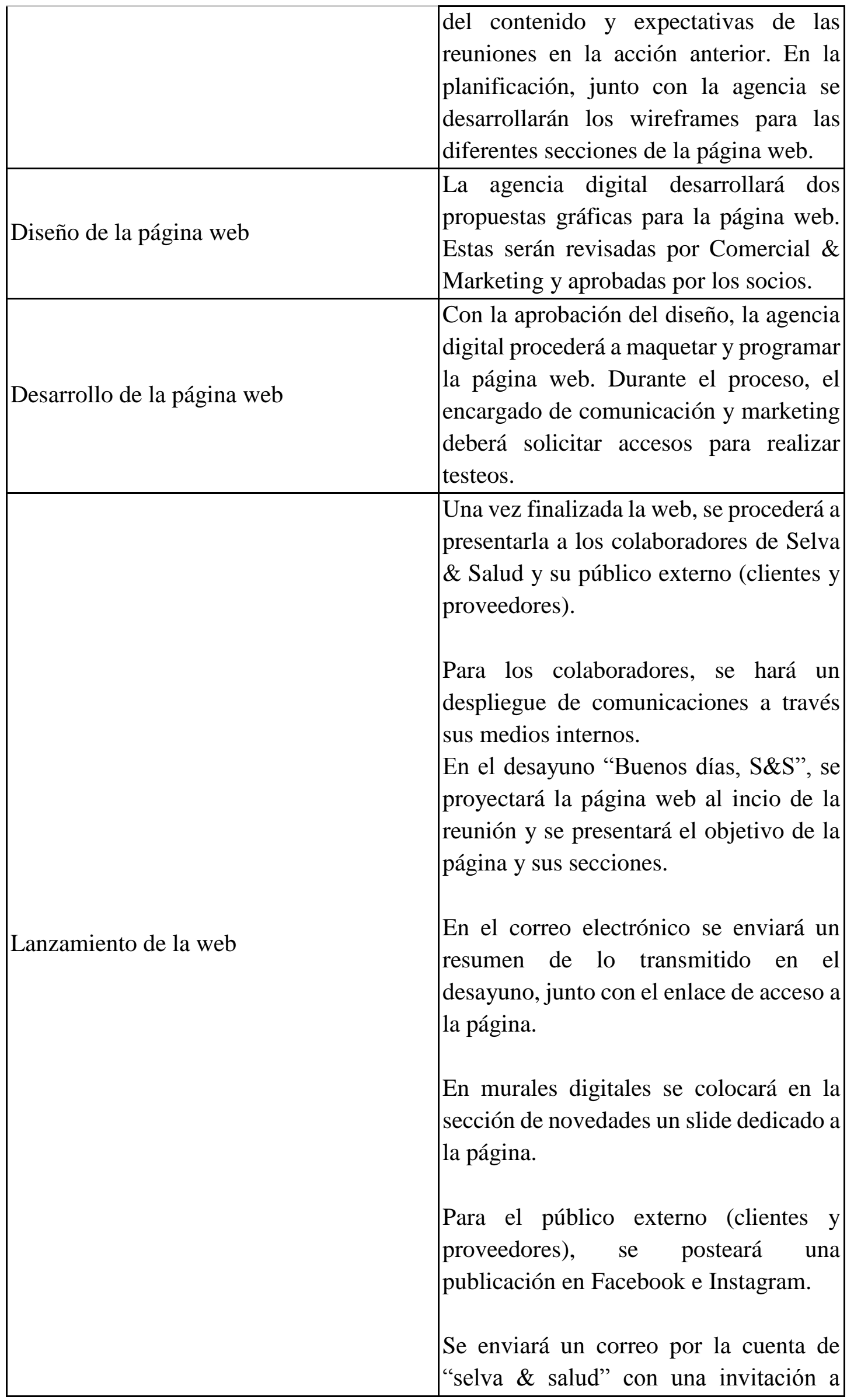




\begin{tabular}{|c|c|}
\hline & visitar la nueva página de la empresa. \\
\hline Mantenimiento del contenido & $\begin{array}{l}\text { El encargado de comunicaciones deberá } \\
\text { establecer un protocolo de actualización } \\
\text { anual del contenido, de modo que cada } \\
\text { año se revise este y se asegure que esté a } \\
\text { la fecha. } \\
\text { En cuanto a la actualización del blog, que } \\
\text { es la sección más dinámica de la página, } \\
\text { deberá establecer un cronograma de } \\
\text { publicaciones y temas. }\end{array}$ \\
\hline $\begin{array}{l}\text { Rebotar el contenido en las redes sociales } \\
\text { institucionales }\end{array}$ & $\begin{array}{l}\text { Las publicaciones del blog en la página } \\
\text { web se compartirán en Facebook e } \\
\text { Instagram según la plantilla establecida. }\end{array}$ \\
\hline
\end{tabular}

Estrategia 2: Construir la presencia digital en redes sociales

Creación de contenidos para redes sociales

\begin{tabular}{l|l} 
ACCIÓN & DESCRIPCIÓN
\end{tabular}

Se creará contenido según las siguientes categorías:

- Ofertas y promociones: Ofertas con el aceite de coco.

Hashtag: \#AceiteDeCocoParaTi

- Consejos: Tips de consumo responsable y vida saludable. Hashtag: \#TipsS\&S

- Recetas: Comidas o postres preparados con aceite de coco y otros productos orgánicos.

Hashtag: \#ComiendoSaludable

- Estilo de vida saludable: Frases motivadoras para adoptar un estilo de vida saludable.

Hashtag: \#ViveSaludable

- Información institucional corporativa: Anuncios sobre la empresa, eventos donde participa, entre otros, menciones en prensa. También se incluirán saludos por fechas especiales como: Día Forestal Mundial (21/03), Día de la 


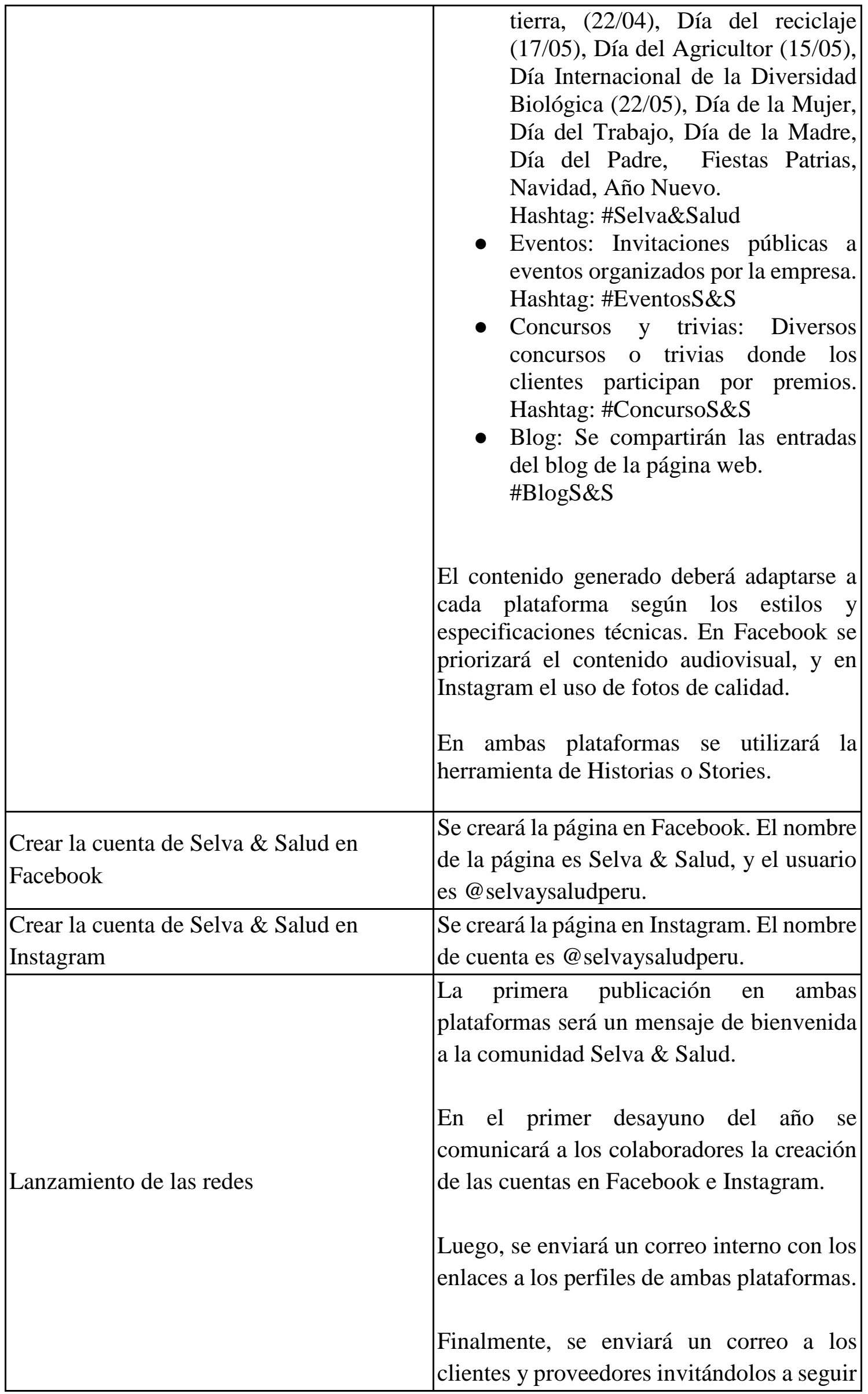




\begin{tabular}{|c|c|}
\hline & $\begin{array}{l}\text { las redes de la empresa con el enlace de } \\
\text { acceso. }\end{array}$ \\
\hline $\begin{array}{l}\text { Mantener y actualizar regularmente las } \\
\text { redes }\end{array}$ & $\begin{array}{l}\text { El encargado de comunicaciones deberá } \\
\text { velar por la actualización de ambas redes } \\
\text { según el cronograma y pauta de contenidos. }\end{array}$ \\
\hline Establecer pauta digital & $\begin{array}{l}\text { Luego de obtener un tráfico orgánico en las } \\
\text { redes sociales, se realizará una inversión en } \\
\text { ciertas publicaciones como eventos } \\
\text { importantes y promociones para incentivas } \\
\text { a un mayor alcance en redes. } \\
\text { Para ello, se utilizarán palabras claves } \\
\text { como: } \\
\text { - Ecológico } \\
\text { - Medioambiente } \\
\text { - Aceite de coco } \\
\text { - Saludable } \\
\text { - Productos orgánicos } \\
\text { - Verde } \\
\text { - Ecoamigable } \\
\text { - Ecofriendly } \\
\text { Además, se segmentará de acuerdo a las } \\
\text { edades de nuestro público objetivo y } \\
\text { ubicación. } \\
\text { Al finalizar la pauta se realizará un análisis } \\
\text { del impacto digital (kpi) para seguir } \\
\text { mejorando en ser más efectivos en nuestro } \\
\text { presupusto digital. }\end{array}$ \\
\hline Recopilación de base de datos & $\begin{array}{l}\text { En las publicaciones como concursos o } \\
\text { trivias se incluirá un formulario de } \\
\text { inscripción que servirá para recopilar los } \\
\text { datos de nuestros clientes actuales o } \\
\text { potenciales. }\end{array}$ \\
\hline
\end{tabular}


Estrategia 3: Consolidar el correo Selva \& Salud como medio directo de contacto con el cliente y proveedores

\begin{tabular}{|c|c|}
\hline ACCIÓN & DESCRIPCIÓN \\
\hline $\begin{array}{l}\text { Establecer un protocolo de revisión y } \\
\text { respuesta del correo }\end{array}$ & $\begin{array}{l}\text { El encargado de comunicaciones tendrá la } \\
\text { tarea de revisar constantemente el buzón de } \\
\text { entrada del correo Selva \& Salud para } \\
\text { verificar los correos enviados por los } \\
\text { clientes y darles respuesta. Se revisará todas } \\
\text { las mañanas a primera hora, y nuevamente } \\
\text { al mediodía. } \\
\text { Asimismo, los pedidos deben ser } \\
\text { redireccionados al área de Ventas. Las } \\
\text { consultas, si no las puede responder el } \\
\text { mismo encargado, deberán dirigirse a las } \\
\text { personas correspondientes. }\end{array}$ \\
\hline $\begin{array}{l}\text { Difundir la cuenta de correo por medios } \\
\text { externos }\end{array}$ & $\begin{array}{l}\text { Se publicará la cuenta de correo en } \\
\text { Facebook e Instagram, para que los clientes } \\
\text { sepan que por ese medio pueden hacer } \\
\text { pedidos directamente o a través de la } \\
\text { sección Contacto de la página web (estos } \\
\text { serían medios alternativos a la vía } \\
\text { telefónica de atención al cliente). }\end{array}$ \\
\hline Establecer pauta y cronograma de envíos & $\begin{array}{l}\text { A través de esta cuenta, se enviaran a } \\
\text { clientes y proveedores diversos correos } \\
\text { relacionados a promociones, ofertas y } \\
\text { anuncios. } \\
\text { El encargado de comunicaciones deberá } \\
\text { velar por el cumplimiento de la pauta y } \\
\text { cronograma: dos correos por semana } \\
\text { durante la promoción. }\end{array}$ \\
\hline Diseñar mailings que se enviarán & $\begin{array}{l}\text { El encargado de comunicaciones deberá } \\
\text { diseñar las piezas que se enviarán para las } \\
\text { promociones, ofertas y anuncios. }\end{array}$ \\
\hline
\end{tabular}




\section{Matrices, cronograma y presupuesto:}

Las matrices de comunicación interna y externa, cronograma y presupuesto para el plan estratégico de comunicación se encuentran detallados en el anexo 1.

Anexo 1:

https://drive.google.com/file/d/1H7Na3RF6BQ7A6XYzLqbMw1GJ0khxtaIt/view?usp =sharing

\section{Matríz de plan de comunicación interna:}

https://drive.google.com/file/d/1amyQFVbzIeCKqOJhSzNyQwSHYBRgbalT/view?usp =sharing

\section{Matríz de plan de comunicación externa:}

https://drive.google.com/file/d/1H5NeFSj5M1xMxgX9OWANyknSIsyAbgXz/view?us $\mathrm{p}=$ sharing

\section{Cronograma:}

https://drive.google.com/file/d/1kWPBfcGthxaRjYAQPmK1tlspOOALVTc6/view?usp =sharing

\section{Presupuesto:}

https://drive.google.com/file/d/1HxOQVnCZHo3FleYAZri0DwVOY5yT8Bao/view?us $\mathrm{p}=$ sharing 


\title{
Justificación del presupuesto ante inversionistas:
}

La inversión en el plan de comunicación está justificada por las ventajas que la aplicación de sus estrategias y acciones suponen:

\begin{abstract}
Alineación de los colaboradores a los objetivos corporativos
Todas las acciones internas están buscando desarrollar una relación y conexión mucho más cercana con el colaborador incentivando a la identificación de su día a día con la empresa. Estas acciones están orientadas a ambas sedes, lo hará que tenga un sentido de pertenencia y alineación a los objetivos corporativos, lo cual hará que sean más productivos y generen una mayor rentabilidad a la empresa.
\end{abstract}

\section{Reducción del índice de rotación}

Asimismo, al ver que la empresa está comprometida con el crecimiento personal y, a futuro, al desarrollo y bienestar de su familia, los colaboradores son más fieles a la empresa. El colaborador crece con la empresa y hace crecer a la empresa. Esto resulta en una reducción del índice de rotación del personal por lo que se reducirán los costos en selección, inducciones, capacitaciones y gastos administrativos.

\section{Fortalecimiento de la relación con clientes que recomiendan el producto y atracción de nuevos clientes}

La recomendación del producto por parte de los clientes fidelizados es un activo muy importante para la empresa. Las acciones del plan están orientadas a fortalecer esta relación para poder atraer a nuevos públicos que valoren el consumo responsable. Mientras más personas conozcan, valoren y recomienden el producto, se aumenta el reconocimiento de la marca por lo que para la empresa se generan mayores oportunidades de venta, mayor crecimiento de cartera de clientes, mayores posibilidades de alianzas y mayores ingresos.

\section{Posicionamiento digital}

Las redes sociales hoy en día son un aspecto muy importante para la reputación online de la organización, para dar a conocer su propuesta de valor y para atraer a los clientes en el espacio digital. Una correcta realización de estrategias orientadas a un fortalecimiento del ecosistema digital permitirá a la empresa que más personas lleguen a ella, sigan en sus redes y se de la oportunidad de que se genere un proceso de conversión para que compren el producto a través de estrategias de marketing digital.

\section{Mayor conversión de clientes online}

Se ha identificado que muchas veces el cliente no compra este tipo de productos por desconocimiento o desinformación. Ante ello, a través de nuestros canales externos digitales se ofrecerá de manera eficiente al cliente información y contenido de valor para lograr el proceso de conversión. Este proceso estará soportado por la fuerza de ventas y la atención al cliente que será personalizada para que el cliente se sienta a gusto y se pueda generar una recompra. 


\section{CAPÍTULO V: ESTRATEGIA CREATIVA}

\section{Elección de contenidos}

\subsection{Nivel de cambio}

De acuerdo al diagnóstico realizado sobre la organización, el nivel de cambio a realizar será de la fase de desconocimiento al conocimiento de la cultura Selva \& Salud a través del diseño de estrategias de comunicación que logren transmitir los propósitos generales y los orientados a los colaboradores, clientes y comunidad, así como la misión, visión y la propuesta de valor. De esta manera, se busca potenciar el engagement de los stakeholders involucrados.

1.2. Contenidos aplicados a la estrategia

Los contenidos a utilizar para la estrategia creativa son:

Contenidos conceptuales: Los grupos de interés mantienen un conocimiento relacionado con la cultura actual de la empresa. A pesar de que esta no se encuentra conceptualizada y declarada de manera formal, representa las actitudes, comportamientos, creencias y valores que se viven actualmente en la organización.

Es así que, con el objetivo de poder definir una cultura deseada en la organización y que cale en los grupos de interés, es necesario enseñar a los públicos involucrados sobre a filosofía corporativa de Selva \& Salud para lograr el nivel de cambio deseado. De esta forma, las definiciones a comunicar son:

\section{Propósito}

Somos Selva \& Salud, una empresa peruana familiar, ecoamigable y comprometida con fomentar el consumo responsable del aceite de coco y otros productos orgánicos nacionales en las familias peruanas, generando así un desarrollo sostenible en las comunidades productoras de la amazonía peruana.

\section{Misión}

Ofrecer a nuestros clientes un aceite de coco de calidad superior, frescura y $100 \%$ natural, a través de una atención cercana y confiable que refleje nuestra tradición y compromiso con la comunidad y conservación del ecosistema.

\section{Visión}

Ser la principal opción para el consumo del aceite de coco y otros productos orgánicos que constribuya al crecimiento de una cultura ecoamigable en el Perú en los próximos cinco años. 


\section{Valores}

1. Somos responsables: Nuestra trayectoria respalda la transparencia y calidad que buscamos transmitir cada día desde nuestro rol; en la optimización de la cadena de valor de cada producto, así como en el contenido que ofrecemos a los grupos de interés con los que intactuamos para incentivar un consumo responsable.

2. Crecemos en equipo: Nuestros colaboradores son lo más importante; por ello, buscamos brindarles oportunidades para su desarrollo personal y profesional desde un ambiente de compañerismo, trabajo colaborativo y de corazón verde que les permita lograr sus metas y agregar valor a la empresa.

3. Valoramos la diversidad: La riqueza de nuestro equipo, ubicado en la región de San Martín y Lima, nos permite unificar diversos talentos, apreciaciones, gama de conocimientos y experiencias en la generación de valor de nuestros productos y la atención personalizada que buscamos ofrecerle a nuestros clientes.

4. Estamos comprometidos con el medioambiente: Ante los diversos desafíos por los que atraviesa el planeta, nuestro propósito en la sensibilización ambiental es cada vez más importante. Creemos en el desarrollo sostenible y la protección del ecosistema, por lo que tratamos de reducir el impacto negativo de nuestras operaciones en el entorno. Además, el compromiso sincero que mantenemos con las comunidades productoras de la selva, nos lleva a apostar por su sostenibilidad y crecimiento.

5. Vivimos la creatividad e innovación: Siempre buscamos nuevas formas de hacer nuestro trabajo para lograr más y mejores resultados. Desde el rol de cada uno, fomentamos la generación de ideas creativas que desafíen los paradigmas y nos lleven a transformar nuestra realidad hacia un estilo de vida ecoamigable.

Contenidos procedimentales: Luego de definir los conceptos mencionados anteriormente, es importante que los grupos de interés involucrados puedan aprender los pasos o procesos para lograr la aplicación de la filosofía corporativa de manera alineada. En este caso se definirá el concepto "consumo responsable", ubicado dentro de nuestro propósito, y los valores.

¿Cómo fomentamos un consumo responsable?

- En nuestros colaboradores: Garantizando un proceso de producción orgánico que respete los más altos estándares de calidad y que busque siempre la mejora contínua y excelencia en beneficio y satisfacción de nuestro personal y clientes.

Escuchando y apoyándonos de nuestros clientes para continuar innovando y creando nuevos productos con el sello de calidad que nos representa.

- En nuestros clientes: Brindando a nuestros clientes información actualizada, accesible y de valor para que conozcan los beneficios de consumir productos más sostenibles y adopten un estilo de vida saluble y ecoamigable.

- En nuestra comunidad: Velando por el desarrollo de las familias que nos proveen con la base de nuestros productos y protegiendo el ecosistema para asegurar su sostenibilidad. 
¿Cómo se aplican los valores?

\section{Somos responsables:}

- Siendo ejemplo de lo que pregonamos.

- Reconociendo y comunicando mejoras en la cadena de valor o dando a conocer malas prácticas dentro de la empresa.

- Verificando que el contenido ofrecido a nuestros clientes sea de calidad, actualizado y relevante.

\section{Crecemos en equipo:}

- Uniendo talentos para crear propuestas de valor innovadoras para el negocio.

- Reconociendo mis fortalezas y puntos a mejora y brindando feedback, de forma respetuosa y consciente, a nuestros compañeros con el objetivo de apoyar a su desarrollo.

- Generando proyectos, acciones o mensajes de integración, diálogo y unidad en cada sede y de manera integral.

\section{Valoramos la diversidad:}

- Respetando las necesidades y puntos de vista de nuestros compañeros.

- Escuchando de forma activa lo que el otro me quiere decir.

- Invirtiendo parte de mi día en poder conocer más a mis compañeros de ambas sedes.

\section{Estamos comprometidos con el medioambiente:}

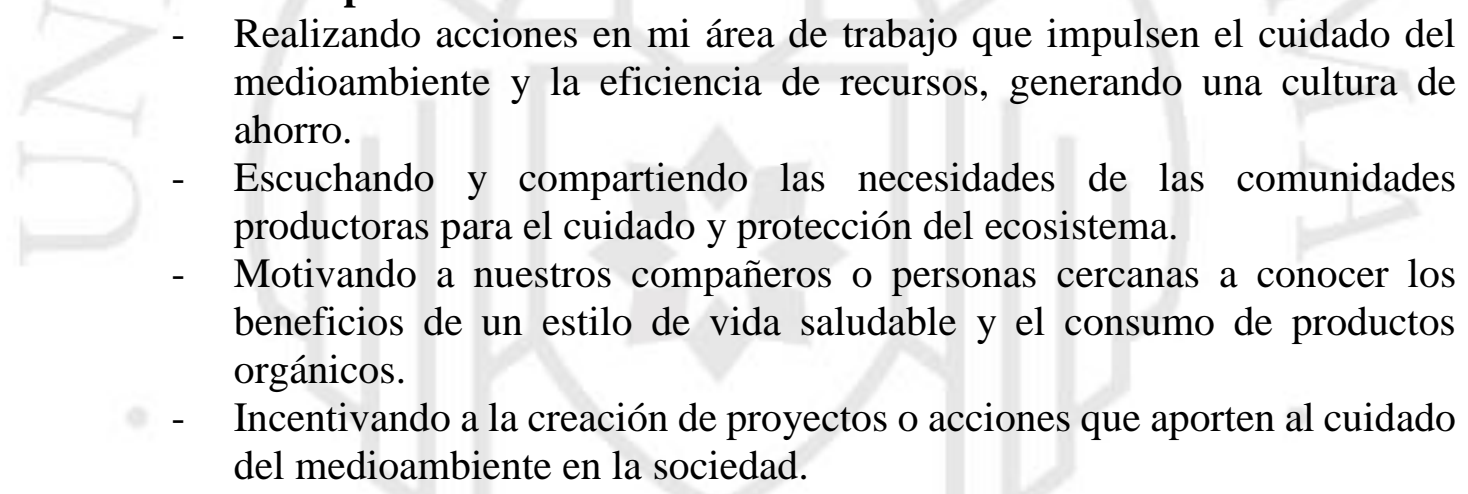

\section{Vivimos la creatividad e innovación:}

- Empleando la tecnología para continuar mejorando en nuestros productos.

- Fomentando la creación de proyectos multidisciplinarios.

- Informándome sobre las tendencias relacionadas al estilo de vida saludable, así como de las mejores prácticas empleadas.

- Aplicando metodologías ágiles y creativas para la generación de nuevas ideas que aporten en el crecimiento de nuestra cartera de productos y la experiencia al cliente.

Contenidos actitudinales: Para el siguiente contenido se colocarán las motivaciones y beneficios, así como las barreras y frenos frente a la práctica de la filosofía corporativa Selva \& Salud

\section{Lista de barreras y frenos}

- La empresa ha crecido sin un propósito organizacional claro, no obstante, puede generarse cierta aversión al cambio frente al establecimiento de la nueva cultura.

- Falta de identificación, unidad y empatía de las necesidades y realidades entre los colaboradores de San Martin y los de Lima. 
- Los espacios de integración y comunicación interna no se encuentran del todo definidos.

- Los nuevos accionistas que ingresarán al negocio no se encuentran completamente alineados con la estrategia de los socios fundadores de apalancarse en la comunicación.

\section{Beneficios y motivaciones}

- Trayectoria de la empresa familiar.

- Inicio y crecimiento de la empresa basada en una filosofía eco-amigable y la vida saludable de los peruanos alineada a las tendencias del mercado actuales.

- Comunicación cercana con el cliente mediante los canales de la empresa.

- Motivación de los socios por mejorar la comunicación interna.

- Estrecha relación de casi 10 años con las comunidades productoras de Coco Bosque con las que se mantiene una alianza (ONG AMPA), contribuyendo a su sostenibilidad.

- Las comunidades de la selva con las que se trabaja conjuntamente, cuentan con la misma concientización ambiental, el consumo responsable para la preservación de los ecosistemas y el valor de la selva.

- El producto produce en condiciones amigables con el medioambiente.

- El aceite de coco cuenta con diversos atributos y aplicaciones.

- Reconocimiento de la marca en bioferias y entre los principales clientes.

- Clientes fidelizados.

\section{Concepto creativo}

Para lograr el cambio deseado, se realizó la estrategia creativa, donde se pudo reconocer los conceptos y procedimientos, asi como las motivaciones y barreras involucradas. Es así que, ante los beneficios y la necesidad de abordar de manera exitosa el cambio, las nuevas tendencias en crecimiento, los atributos resaltantes y el potencial diferencial de la marca se crea el concepto creativo "Viviendo la cultura Selva \& Salud". A continuación la explicación de las palabras empleadas:

\section{"Viviendo la cultura Selva \& Salud"}

"Viviendo": Gerundio regular que desmuestra una acción que está en desarrollo. El uso de la palabra busca que la cultura, y los elementos que esta conlleva, sean reconocidos por el colaborador para luego hacerlos suyos. De esta forma, se mantendrá una cultura viva que se encuentre en continuo crecimiento y transformación. Ante esta aplicación, la finalidad es que el colaborador sea consciente de la misma y se sienta cómodo e identificado al llevarla a cabo. Una cultura enrraizada construirá el sello diferencial de Selva \& Salud, transmitiéndose desde el interior de la organización hacia afuera.

Desde la mirada externa, se busca que los clientes y proveedores puedan reconocer los atibutos de la marca en cada interacción, fidelizándose con la propuesta de valor que ofrece la organización en sus productos y las experiencias positivas que mantienen con Selva $\&$ Salud, las cuales se reflejan en su cultura.

"Cultura": La cultura es la viva imagen, la base de la organización; es la identidad y personalidad de una institución. El poder mantener una visión alineada, proporcionada por una cultura fuerte, traerá diversos beneficios a la organización como: 
- Creación de la identidad de la empresa: los colaboradores estarán más inclinados a tener prioridades y metas si la cultura de la institución lo refleja.

- Desarrollo del talento: al vivir con una visión compartida, los colaboradores podrán desarrollar todas sus capacidades para lograr los objetivos propuestos por la empresa, generando así oportunidades de crecimiento profesional y personal.

- Retención de colaboradores: compartir todos los mismos valores organizacionales ayudará a la productividad y el trabajo en equipo, evitado reemplazos continuos.

- Comunicación alineada: al existir una integración entre los miembros de una institución, la comunicación se vuelve más abierta, produciendo mensajes más claros y consistentes y aprendidos.

- Usuarios fidelizados y satisfechos: los colaboradores estarán comprometidos con brindar la mejor experiencia al cliente.

- Diferenciación con otras instituciones: la cultura puede convertirse en la propuesta de valor de la institución, haciéndola sobresalir.

(Expoc 2019)

Una cultura corporativa próspera que involucre a los colaboradores, generará un retorno de inversión a través del éxito de los productos, personas, usuarios y marcas de la institución. :

Además, es importante indicar que la cultura es dinámica, cambiante y evoluciona con el tiempo y las nuevas experiencias; aspectos que serán abordados y reforzados por la definición de la palabra "viviendo", así como el valor corporativo de "innovación y creatividad identificado para la organización.

Selva \& Salud: el uso del nuevo nombre de la empresa como parte del concepto creativo, aporta a generar identidad de marca ya que presenta dos palabras importantes que reflejan parte de la razón de ser de la organización. Por un lado, la "selva" es donde se produce el producto ecológico y donde se mantiene una relación cercana con las comunidades de San Martín en un entorno de apoyo mutuo, cuidado del medioambiente y crecimiento para las familias de la región. Por otro lado, "salud" es un estado de bienestar físico y mental para el cual se busca contruir con el propósito de incentivar el consumo responsable desde la producción del producto hasta los contenidos de valor alineados al mismo y a la tendencia saludable.

Asimismo, también se busca que, al mantener presente el nuevo nombre y relacionarlo con la cultura de manera continua, los grupos de interés lo reconozcan y lo asocien a los atributos de la marca. Como abreviación se utilizara en algunas ocasiones "S\&S" para facilitar su recordación. 


\subsection{Llamado a la acción}

Para el call to acción se eligió la frase "Viviendo la cultura S\&S, ¿te unes?". De esta manera, se busca seguir invitando a que más personas puedan ser parte, ya sea como colaboradores y/o clientes, de la empresa, incentivando así a un consumo responsable en crecimiento. 


\section{CAPÍTULO VI: IDENTIDAD CORPORATIVA}

\section{Diagnóstico de identidad}

Actualmente, la empresa no cuenta con una identidad definida. Este punto es necesario pues la identidad define una visión propia que es prospectiva y creativa, una misión que la empresa asume y unos valores que son su guía y filosofía (Costa, 2004, p.63).

La identidad de la empresa se concreta de manera gráfica en lo que conocemos como identidad corporativa o visual. Según Aljure (2015, p.246), esta concreción gráfica debe reflejar los valores y atributos de la organización, y la herramienta que plasma todas los lineamientos y consideraciones para transmitir esta identidad visual sería el manual de identidad.

Este manual debe contener las aplicaciones a través de diferentes soportes, sean internos o externos, y su correcta implementación de parte de todos los miembros de la organización.

\section{Establecimiento de los objetivos corporativos}

\section{Objetivo principal}

Proyectar de manera homogénea la personalidad de marca Selva \& Salud, transmitiendo así la esencia, valores, tono y estilo de comunicación, que permitiran su identificación por los diferentes grupos de interés con los que interactúa, generando una experiencia única de marca.

¿Cómo lo lograremos?

Creando y definiendo la identidad corporativa de Selva \& Salud con la aplicación de un manual que permita alinear a la marca en sus diferentes presentaciones, espacios y soportes físicos y digitales con el objetivo de proyectarla de manera homogénea.

Objetivos internos a la organización

- Proyectar coherencia y unidad de la identidad corporativa Selva \& Salud a lo largo de la cadena de valor.

- Generar sentido de pertenencia por los colaboradores en San Martín, Lima y comunidades selváticas a través del establecimiento de un imagotipo único con sus diversas aplicaciones que genere una identificación sostenible en el tiempo. 
Objetivos externos a la organización

- Generar la recordación de las características visuales de la marca Selva \& Salud, en los clientes, proveedores, sociedad y demás grupos de interés involucrados.

- Producir la identificación de la marca con atributos asociados al posicionamiento de "Selva \& Salud".

\section{Configuración de la identidad visual corporativa}

Para la realización del manual, se ha utilizado el siguiente contenido:

- Imagotipo: El imagotipo busca transmitir tropicalidad y origen natural y orgánico de Selva \& Salud por lo que se han empleado imágenes vectoriales que reflejan los conceptos indicados. La unión de los objetos de este logo atraen la vista y cuentan parte de la historia de la empresa.

- Simbología: Se han aplicado imágenes como el coco, aceite, rocio de lluvia y las palmeras mu características de la zona de producción en San Martín. De esta manera, se buscan transmitir los atributos orgánicos, de producción saludabel y el origen y la importancia de la selva peruana en este proceso.

- Modulación: Medidas del logo

- Área de protección: Tamaños para formato digital e impresión

- Reducción mínima: Tamaños para formato digital e impresión

- Tipografía: Uso de la tipografia ABeeZee. La tipografía es san serif, lo que le da un estilo cercano, casual. La forma de la letra la hace legible y fluida.

- Colores: Los colores utilizados para el imagotipo son verde, gris, negro y blanco. El uso de estos colores refleja la naturaleza del producto, así como un estilo innovador y profesional que permitirá una comunicación limpia y creativa.

- Variaciones permitidas: El uso de colores claros y oscuros permite realizar diversas combinaciones. Ello da a los diseñadores de las piezas y comunicaciones de tener una gama de posibilidades para su aplicación e inspiración.

- Variaciones no permitidas: Usos del logo no permitidos

- Tramas modulares: Las imágenes vectoriales permiten su uso como patrones, en tamaños grandes con diversas combinaciones.

- Fotografías. La fotografía es un aspecto muy importante en la identidad corporativa, ya que permite conocer, sentir y expresar lo que el producto significa y su conexión con el medioambiente. Es así que la fotografía de Selva \& Salud busca transportarte a una experiencia en la selva peruana llena de texturas, gama de colores y detalles que hacen al producto más cercano al consumidor, generando una conexión mayor.

Con nuestra comunicación, buscamos generar engagement con el público y también educarlo. Dado que el propósito es conectar con el público, nuestro tono de comunicación es cercano y de carácter inspiracional. Asimismo, al buscar brindar que el contenido sea relevante para el consumidor apostando por el consumo responsable y el cuidado del medio ambiente, el tono de comunicación es informativo y de carácter de recomendación.

Toda la identidad gráfica de Selva \& Salud se encuentra contenida en su Manual de Identidad. 
Manual de identidad:

https://drive.google.com/file/d/1GBIysPSxPh-

WPn27Bojwx3eChTg91A8w/view?usp=sharing

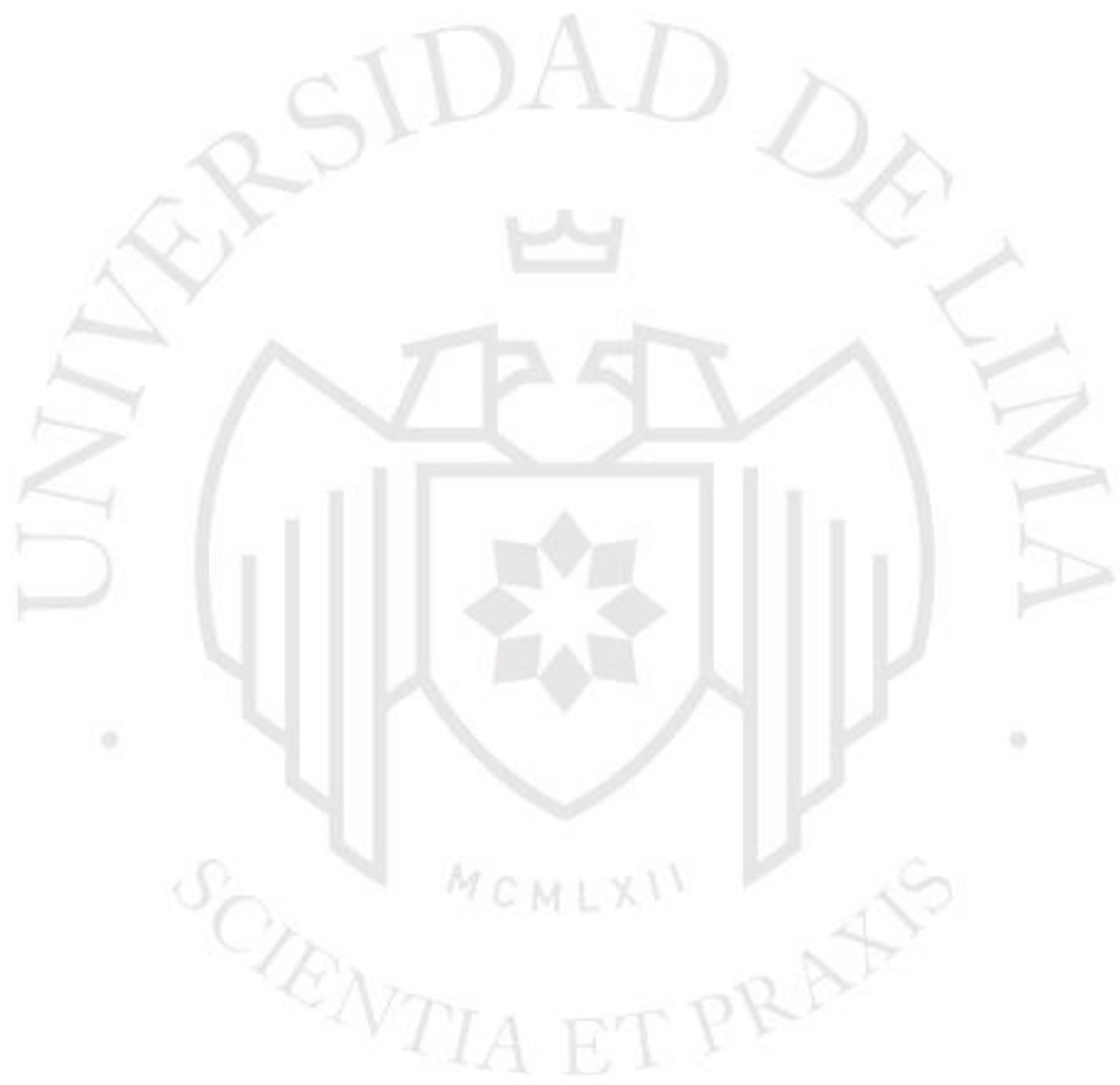




\section{CAPÍTULO VII: CANALES ESTRATÉGICOS DE COMUNICACIÓN}

Como parte del plan estratégico, se proponen los siguientes canales de comunicación:

\section{Presenciales}

- ¡Buenos días, S\&S!

Se trata de reuniones a primera hora donde se convocará a todo el personal con una duración de una hora. Cada desayuno tendrá una agenda establecida. En ellos, se podrá compartir información sobre la filosofía de la empresa, temas relevantes que se necesite que los colaboradores conozcan, avisos administrativos, entre otros. Asimismo, se aprovechará este espacio como canal para difundir las campañas internas de comunicación.

Estos se realizarán una vez por mes.

Se conectará a través de videollamada a los colaboradores de Lima y San Martín.

- Reuniones internas

Cada área tendrá reuniones periódicas para revisar los avances, logros y tener un espacio de feedback entre sus miembros.

\section{Online}

\section{- Comunidad S\&S}

Grupo en Facebook conformado por todos los colaboradores de Selva \& Salud. A través de él, se compartirá contenido generado por el encargado de comunicaciones relacionado a las diferentes campañas internas, novedades, tips sobre el consumo responsable y demás.

\section{- Página en Facebook: Selva \& Salud}

Como parte de la estrategia de comunicación externa, se abrirá una página en Facebook para que sirva como canal de comunicación con el cliente y público en general.

Se generará contenido de interés público relacionado al consumo responsable de productos orgánicos y ecoamigables, dando a conocer así tanto el valor de nuestro producto como nuestra filosofía corporativa.

El objetivo de esta página es generar engagement con el cliente a través de sus publicaciones que se caracterizarán por ser informativas e interactivas. 
En cuanto al contenido informativo, se realizarán publicaciones de fotos del producto y eventos, se publicarán tips para uso del producto, recetas que utilicen el aceite de coco, entre otro tipo de contenidos que involucren el producto y sus beneficios. Estos se realizarán como gráficas, fotos o videos.

Se buscará la interacción con el cliente a través de trivias, enlaces a publicaciones en el blog de la empresa desde la página web, llamadas a la acción para que comenten o sigan la página, concursos, entre otros mecanismos como las Historias.

Se hará uso de los mecanismos para medir el impacto de nuestras publicaciones (analytics).

Es importante recalcar que se espera que a través de las redes sociales sea posible identificar a nuestros clientes y generar así una base de datos.

Enlace: https://www.facebook.com/selvaysaludperu

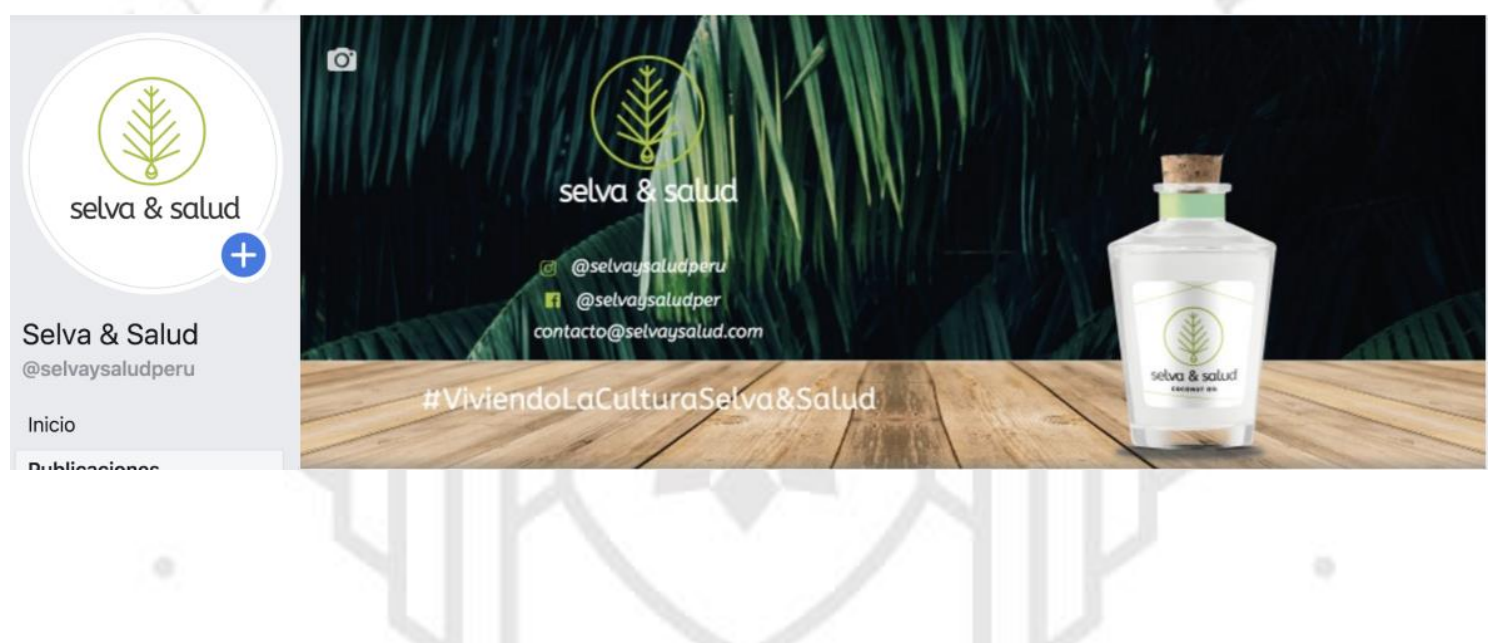

- Perfil en Instagram: Selva \& Salud

Se creará el perfil en Instagram para la empresa. En este se compartirá el contenido de Facebook adaptado a la red social.

El contenido se clasificará por categorías: consejos, recetas, estilo de vida saludable, ecología, información institucional o corporativa como próximos eventos, etc.

Asimismo, se podrá desarrollar contenido para los Stories de Instagram. Estas se clasificarán por categorías y se podrán mantener en su perfil por más de 24 horas.

Enlace: https://www.instagram.com/selvaysaludperu 


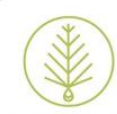

selva \& salud selvaysaludperu Editar perfil 0

12 publicaciones $\quad 4$ seguidores $\quad 1$ seguidos

\section{Selva \& Salud}

Cuidando a las personas y el medioambiente.

Aceite de coco $100 \%$ natural para un estilo de vida saludable.

\#ViviendoLaCulturaSelva\&Salud

\# PUBLICACIONES

$\ominus$ IGTV

П GUARDADO

(1) ETIQUETADAS

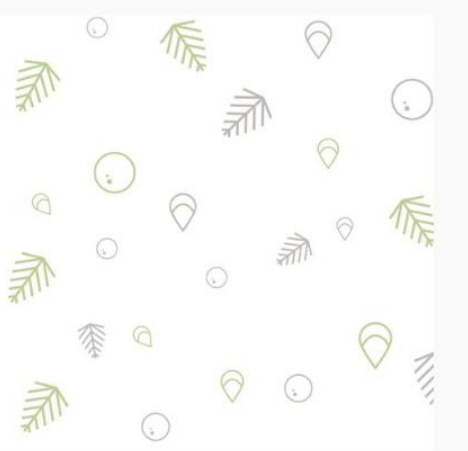

selva \& salud
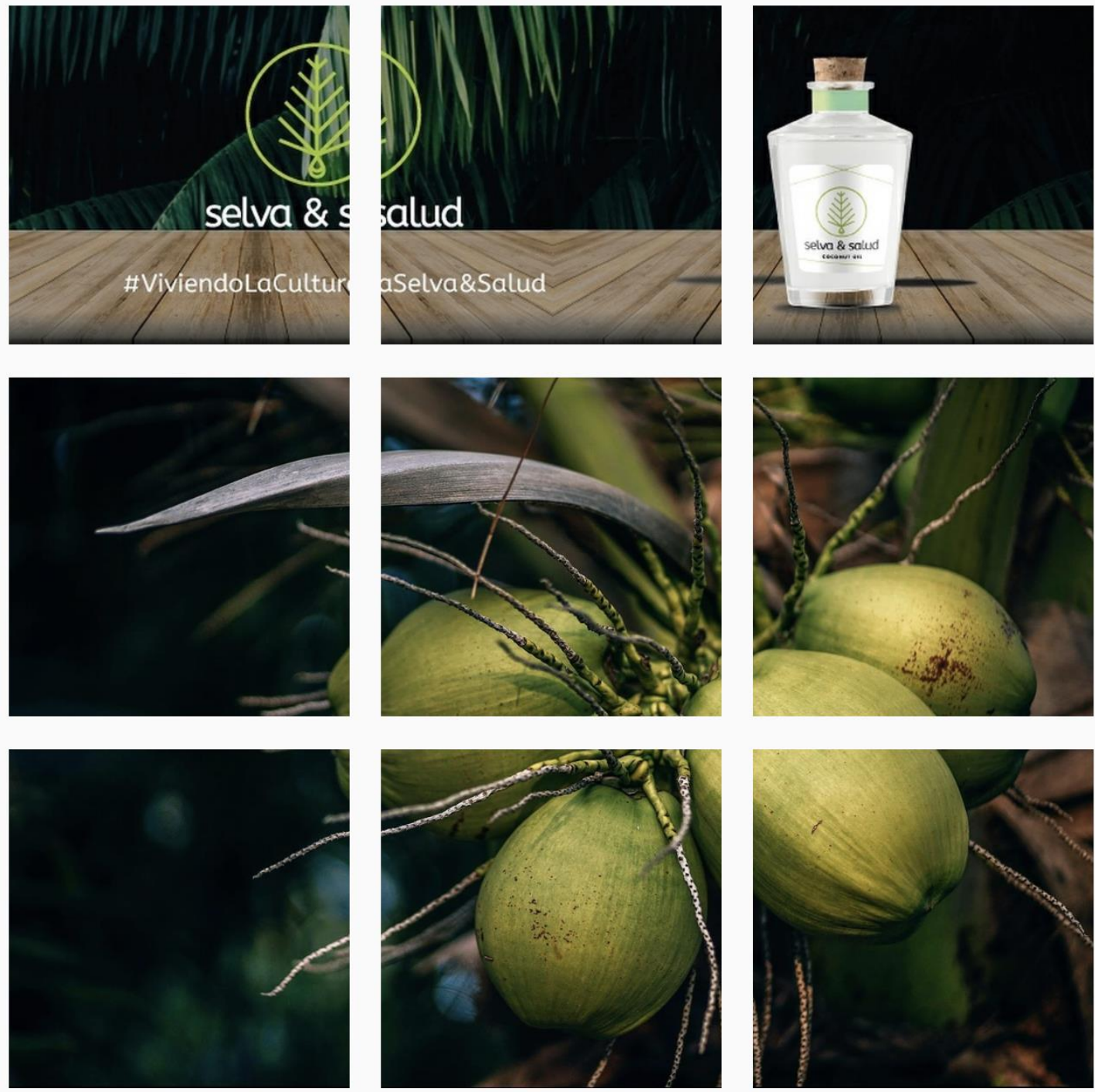


\section{- Página web}

Se implementará la página web corporativa de Selva \& Salud que contendrá información de la empresa, sus productos, y contenido relacionado al consumo responsable, la vida saludable y el estilo de vida ecoamigable.

La página tendrá las siguientes secciones:

1. Inicio: Se colocará un slider con fotos del producto haciendo énfasis en sus principales atributos. En la parte inferior se pondrá la información de la ubicación de los locales, número de contacto para pedidos y horario de atención.

2. Nosotros: Se pondrá el propósito de Selva \& Salud, su misión, visión y valores, así como la explicación de los mismos.

3. Productos: Se incluirá información sobre la presentación y costo del producto, así como una descripción de los principales atributos, usos y beneficios de este.

4. Nuestra comunidad: Se pondrá información sobre la comunidad de Coco Bosque que provee la materia prima para nuestro producto. Se informará sobre el trabajo que hacemos con ellos. Además, se compartirán las experiencias con la comunidad de Lima y San Martín. Adicionalmente, se compartirá contenido de las actividades que se desarrollen en Lima con la comunidad de los distritos aledaños y bioferias.

5. Blog: En el blog, se compartirán artículos relacionados al consumo responsable, vida saludable, estilo de vida ecoamigable. Este contenido será elaborado por el encargado de comunicaciones de la mano de la gente de producción. Asimismo, se podrían poner columnas escritas por los socios.

6. Contacto: Tendrá la información de contacto (teléfono, dirección y correo), así como un formulario para hacer pedidos o consultas.

Enlace: https://andyfarro944.wixsite.com/selvaysalud

\section{- Correo}

Se utilizará el correo interno para comunicar temas puntuales que los colaboradores deban saber.

Se creará un usuario de correo que maneje el encargado de comunicaciones "Selva $\&$ Salud comunica", para que se identifique como el emisor de todas las comunicaciones internas.

Asimismo, hacia afuera se implementará una cuenta Selva \& Salud para enviar correos a los clientes con promociones, ofertas y anuncios. 
Se utilizará Whatsapp para el público interno. El grupo se llamará "Selva \& Salud contigo", y servirà para comunicar recordatorios y temas puntuales que los colaboradores deban saber al instante.

\section{Offline}

\section{- Murales digitales}

Se instalarán pantallas LED en los locales de Lima y San Martin para que sirvan como murales digitales. Estos se actualizarán semanalmente (cada lunes por la mañana) con contenido dividido en las siguientes secciones:

1. Semblanza de la misión, visión y valores

2. Novedades

3. Nuestros eventos

4. Avisos corporativos (temas administrativos)

5. Próximos eventos

6. Cumpleaños

El encaragado de comunicaciones tendrá la labor de generar contenido para cada sección, coordinando si es necesario con otras áreas como recursos humanos y administración. Debe actualizarse cada semana (lunes por la mañana).

El contenido se contendrá en una presentación de Power Point que irá rotando en loop. Luego este será exportado en un usb que se colocará en las pantallas.

En el caso de San Martín, se enviará por wetransfer el archivo a un encargado designado en esa sede para que actualice cada semana los murales.

\section{- Teléfono: Contacto Selva \& Salud}

Es la línea telefónica de atención al cliente de Selva \& Salud. Se difundirá el número por los canales externos de la empresa (Facebook, Instagram y página web) para que los clientes sepan que por esa vía pueden tanto solicitar información del producto como hacer pedidos. 


\section{CAPÍTULO VIII: PRESENTACIÓN DE PIEZAS Y ELEMENTOS INTERNOS Y EXTERNOS}

De acuerdo a los lineamientos presentados en el manual de identidad, se presentarán las piezas y elementos realizados para el Plan de Comunicación Interna y Externa.

\section{Página web}

https://andyfarro944.wixsite.com/selvaysalud

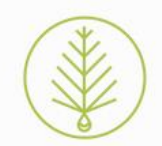

Selva \& Salud

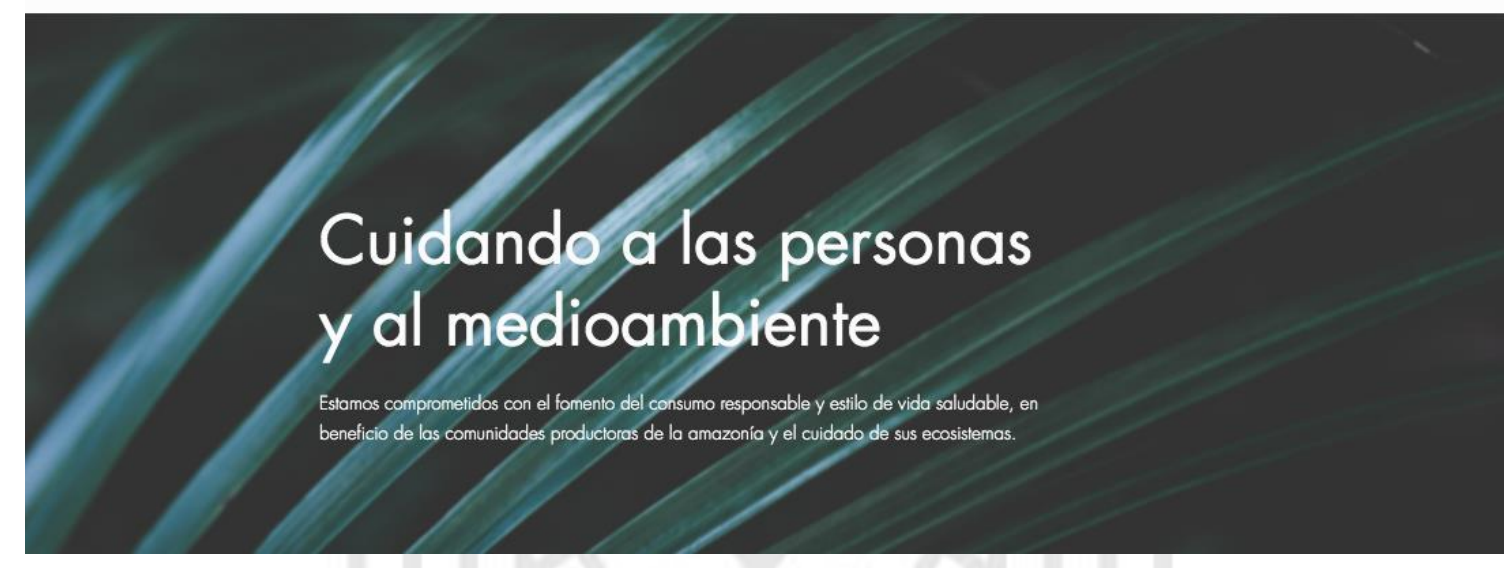



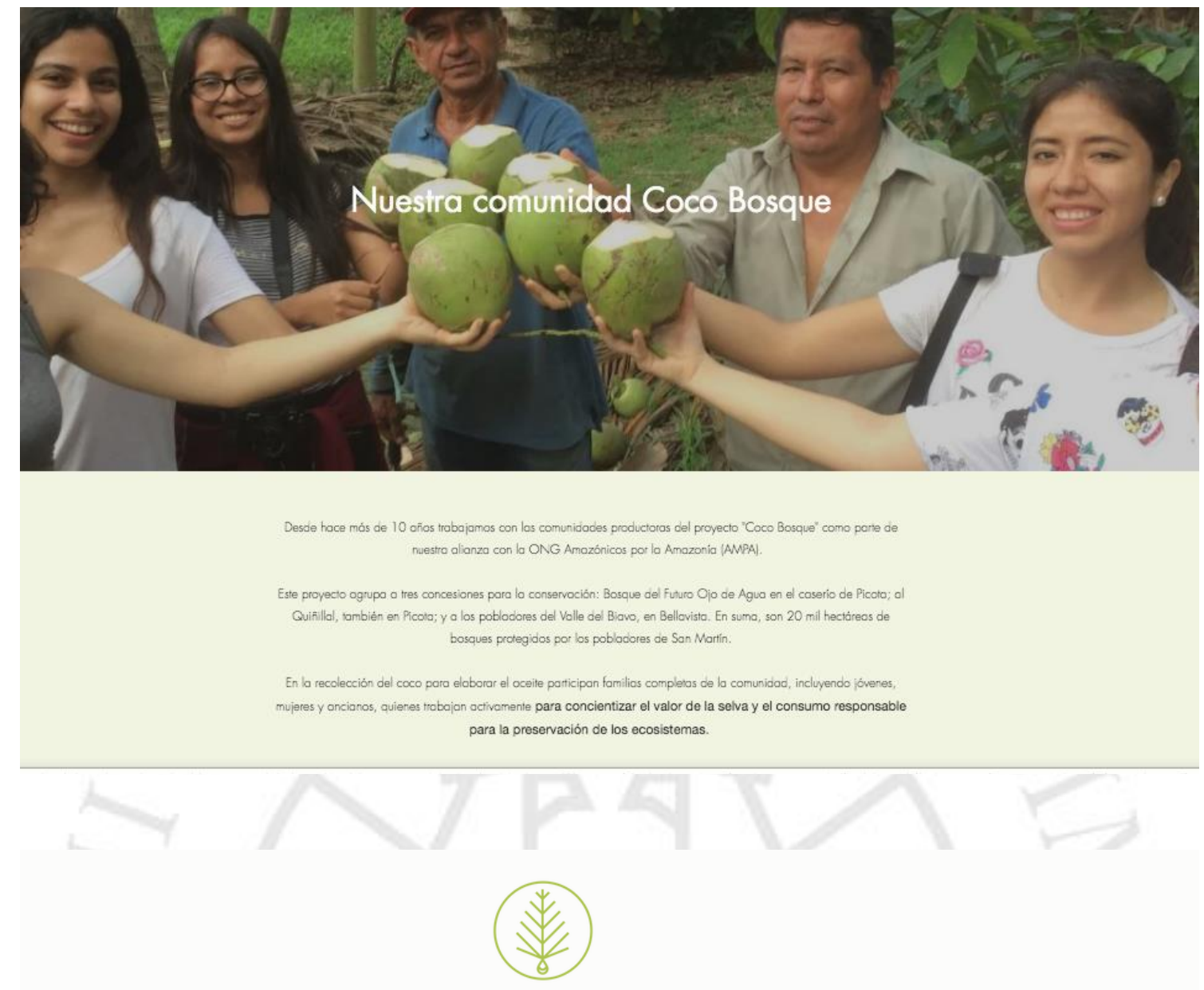

Selva \& Salud

¿Por qué consumir aceite de coco es bueno para mi?

El uso y consumo del aceite de coco orgánico trae muchos beneficios para lograr un estilo de vida saludable y pleno.

- Te ayuda a reducir la grasa abdominal

El aceite de caco extra virgen crudo puede ayudar a perder grasa abdominal.

Los ácidos grasos de cadena media que contiene el aceite de coco no quedan tan almacenados

en el cuerpo en forma de grasa como sí pasa con aquellos ácidos grasos de cadena larga que

tienen otro tipo de aceites. 
Mailing de lanzamiento de las redes sociales Selva \& Salud

https://drive.google.com/file/d/1CILI408RPhwBSpbxzZ0f6rvqTDNx_kP8/view?usp=s haring
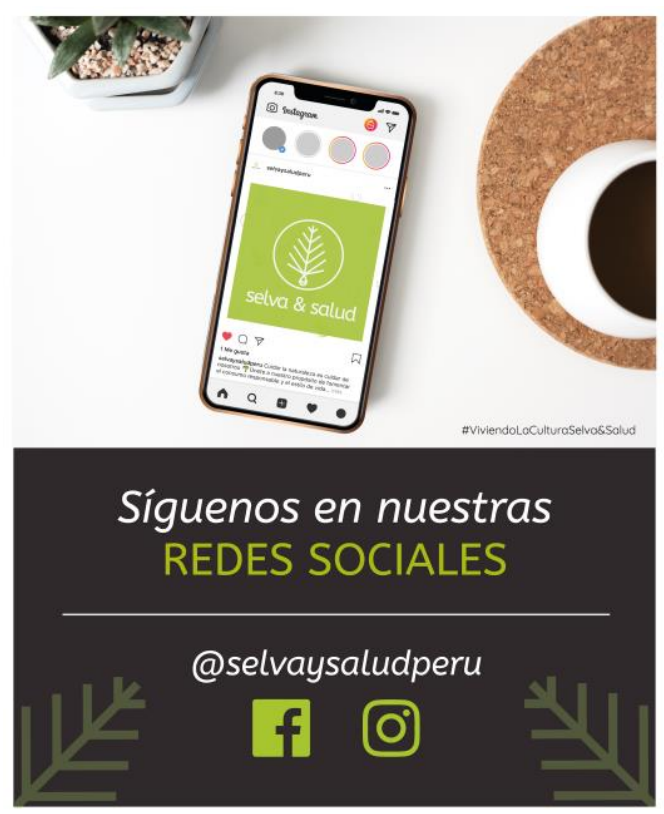

Pedidos: \ $950670318 \approx$ contacto@selvaysalud.com

Publicaciones para el fanpage de Selva \& Salud

https://drive.google.com/drive/folders/1xKAy9UbuOS1Z8ilaD5_GA_0yIOeVqJTb?usp =sharing
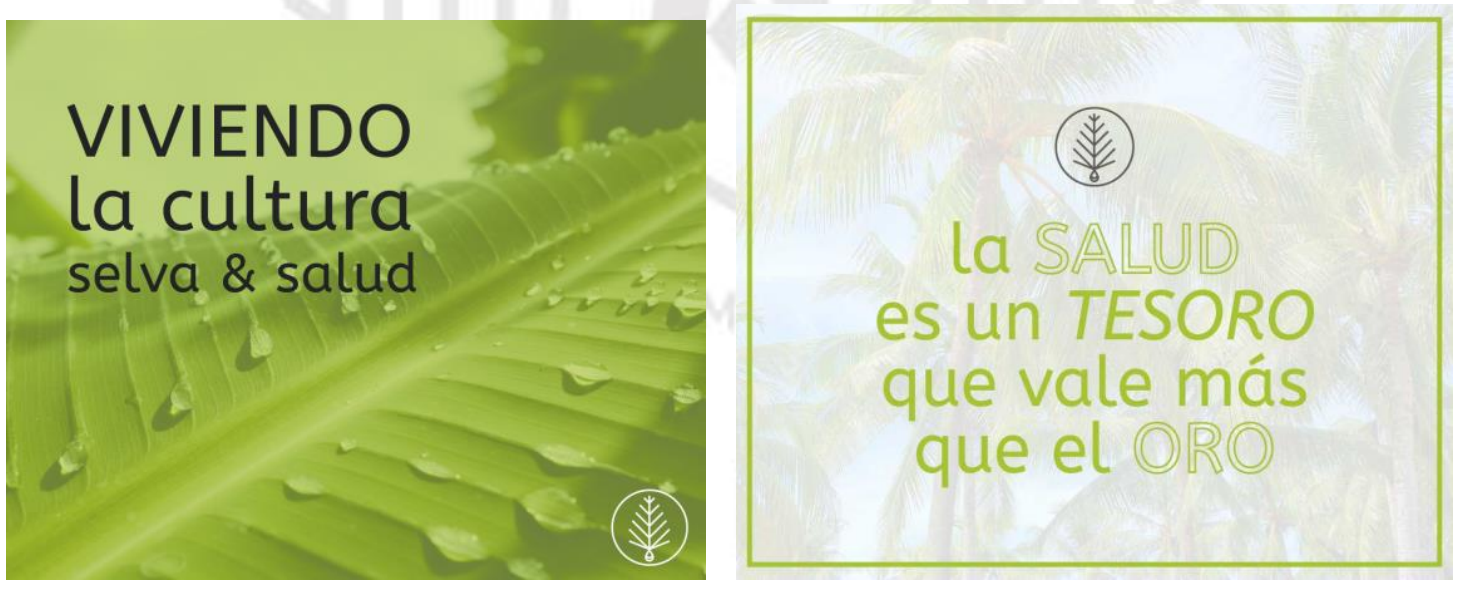

Banner para el fanpage de Selva \& Salud 
https://drive.google.com/file/d/18CXYgc2P8S3rXeiyh9$\underline{\mathrm{P} \text { ePtss} 3 \mathrm{fFdkR} / \text { view? } \mathrm{usp}=\text { sharing }}$

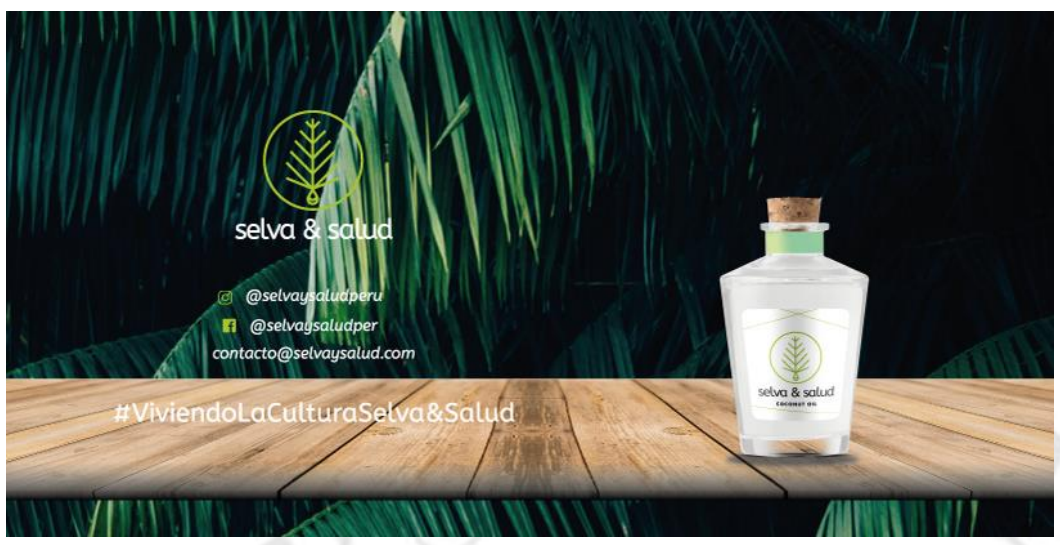

Publicaciones para el Instagram de Selva \& Salud https://drive.google.com/drive/folders/1ofSLnAAqUIKsQAcVvzfrVbkINJZKxLQ?usp=sharing

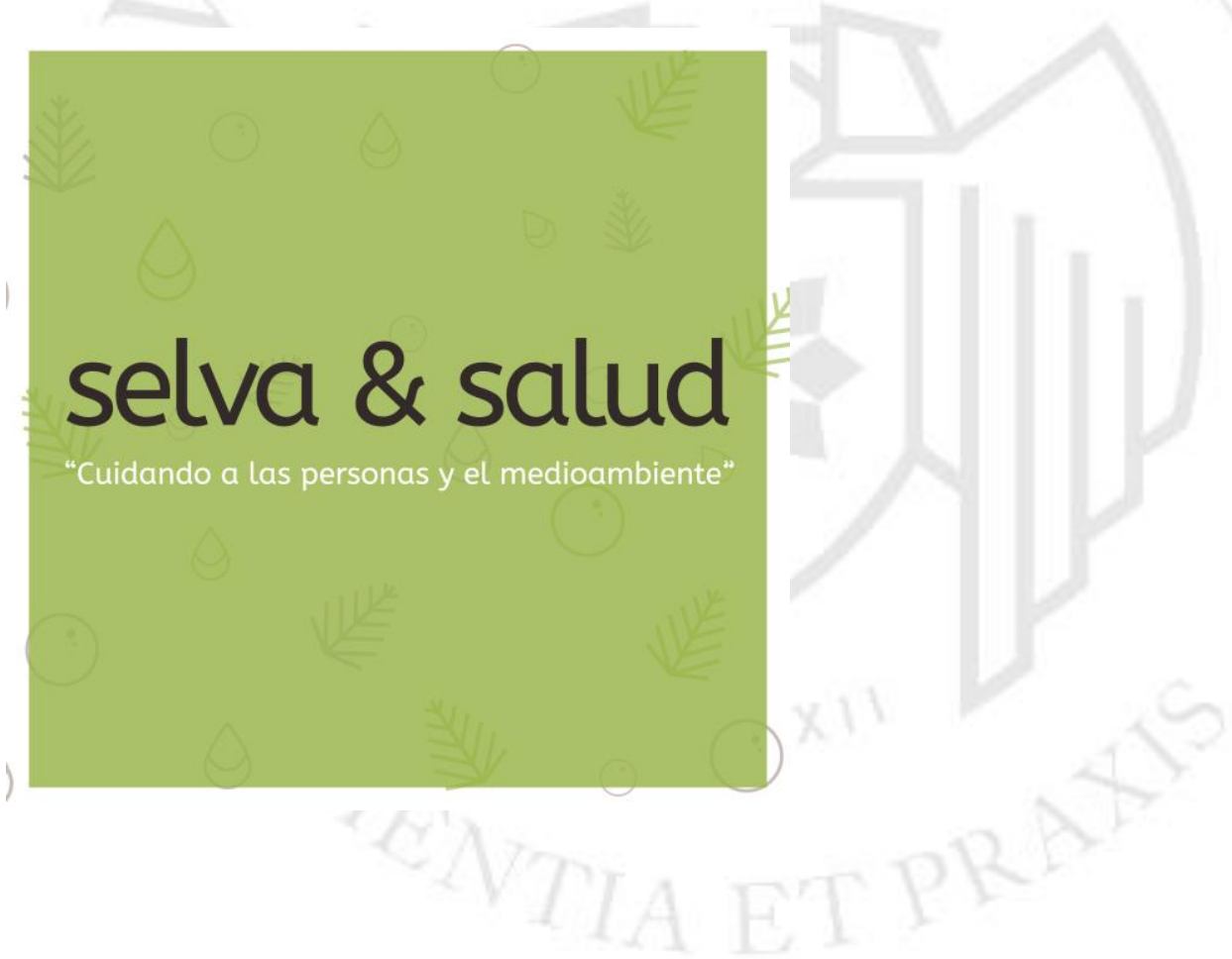

Díptico de filosofía corporativa para los colaboradores de Selva \& Salud https://drive.google.com/file/d/1jLeSs6ib0ESqOB1ApkQuaz togXHseHZ/view?usp=sh aring 

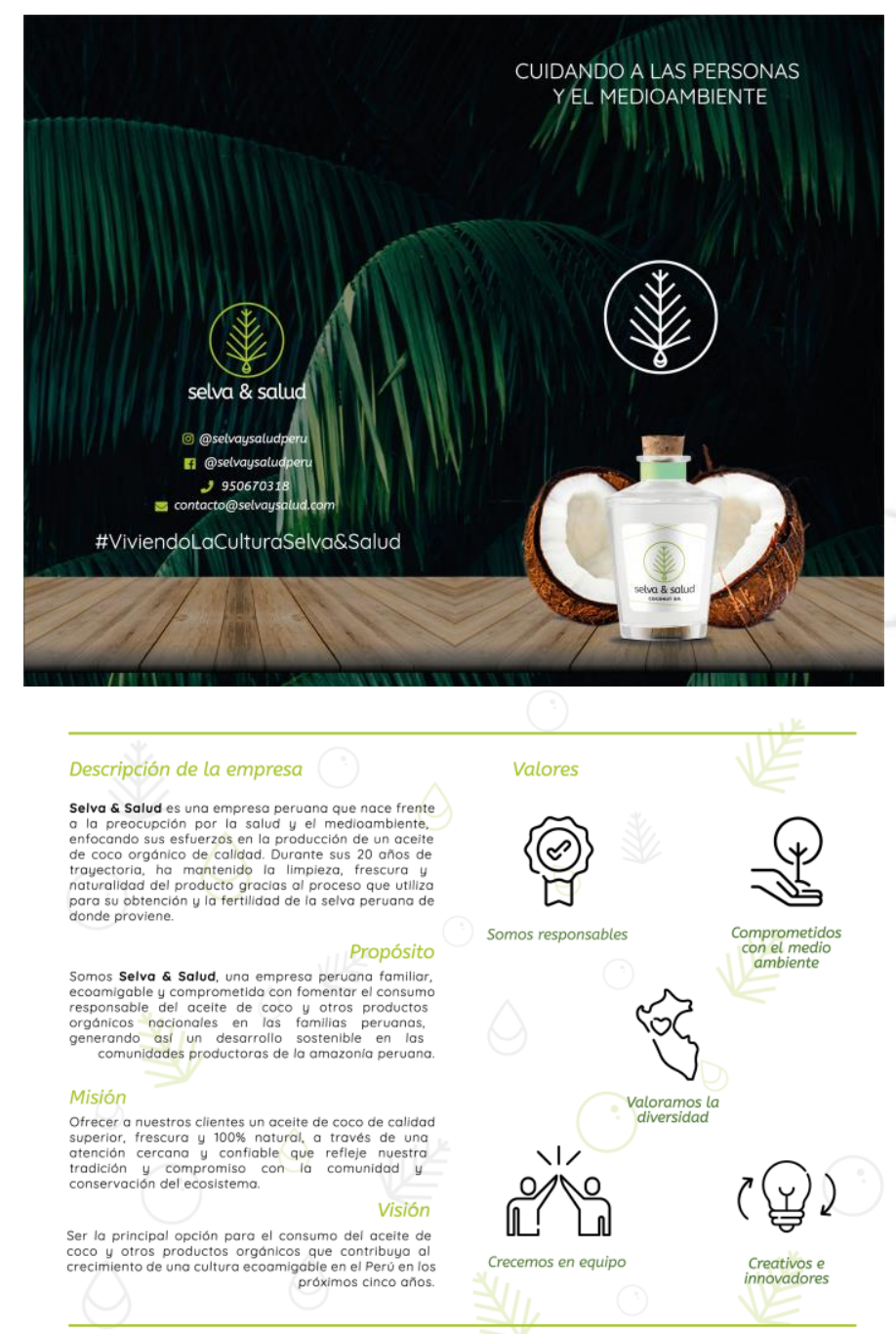
Murales digitales para los colaboradores de Selva \& Salud

https://drive.google.com/file/d/1jQRZ7V52BO0VbcKjngWa7o9cMpvv0Adw/view?usp =sharing

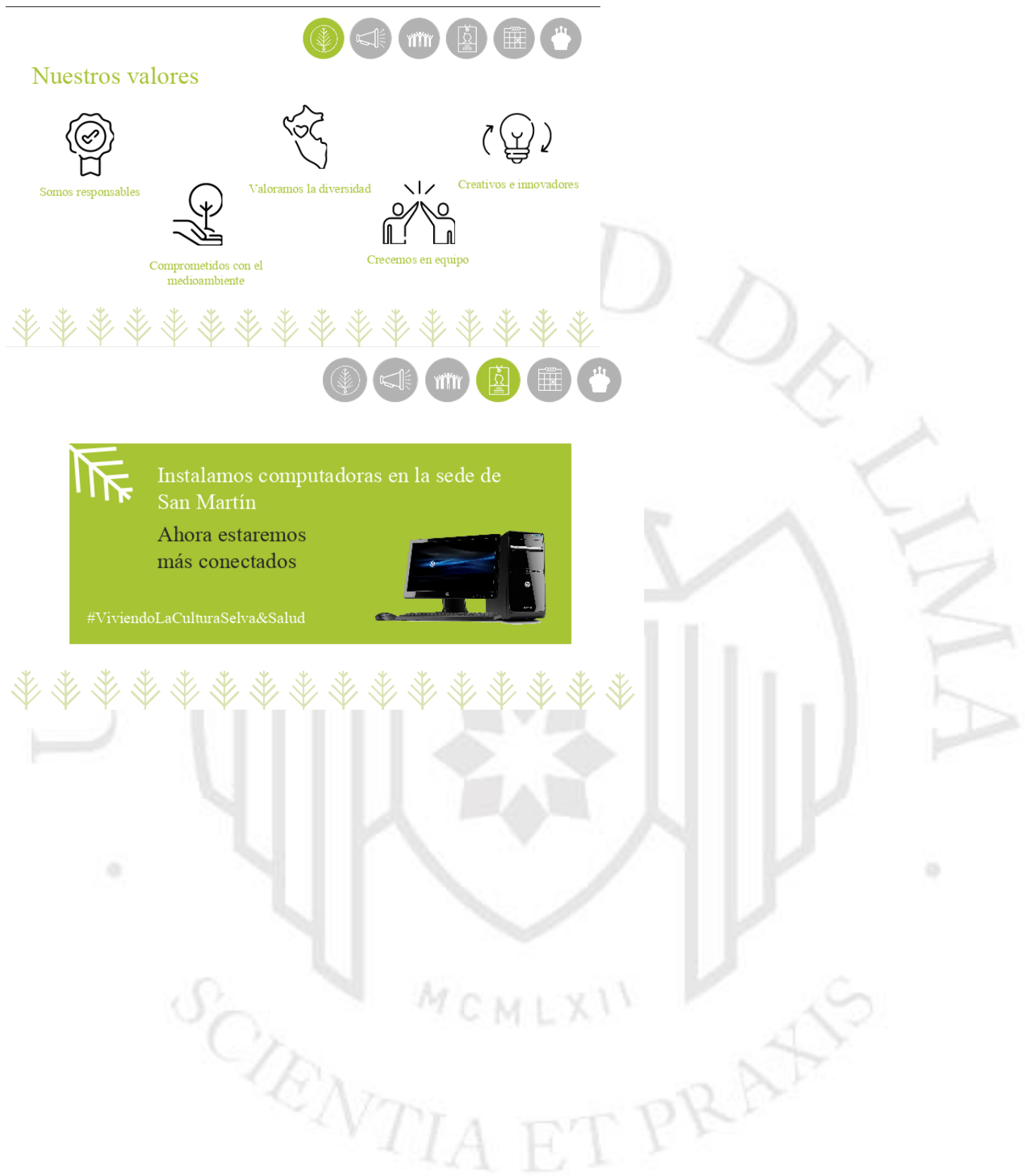




\section{Banner socio Selva \& Salud}

https://drive.google.com/drive/folders/1tuaPZ_d809Qpyp7j_RLdg5UtrZBM4O2?usp=sharing

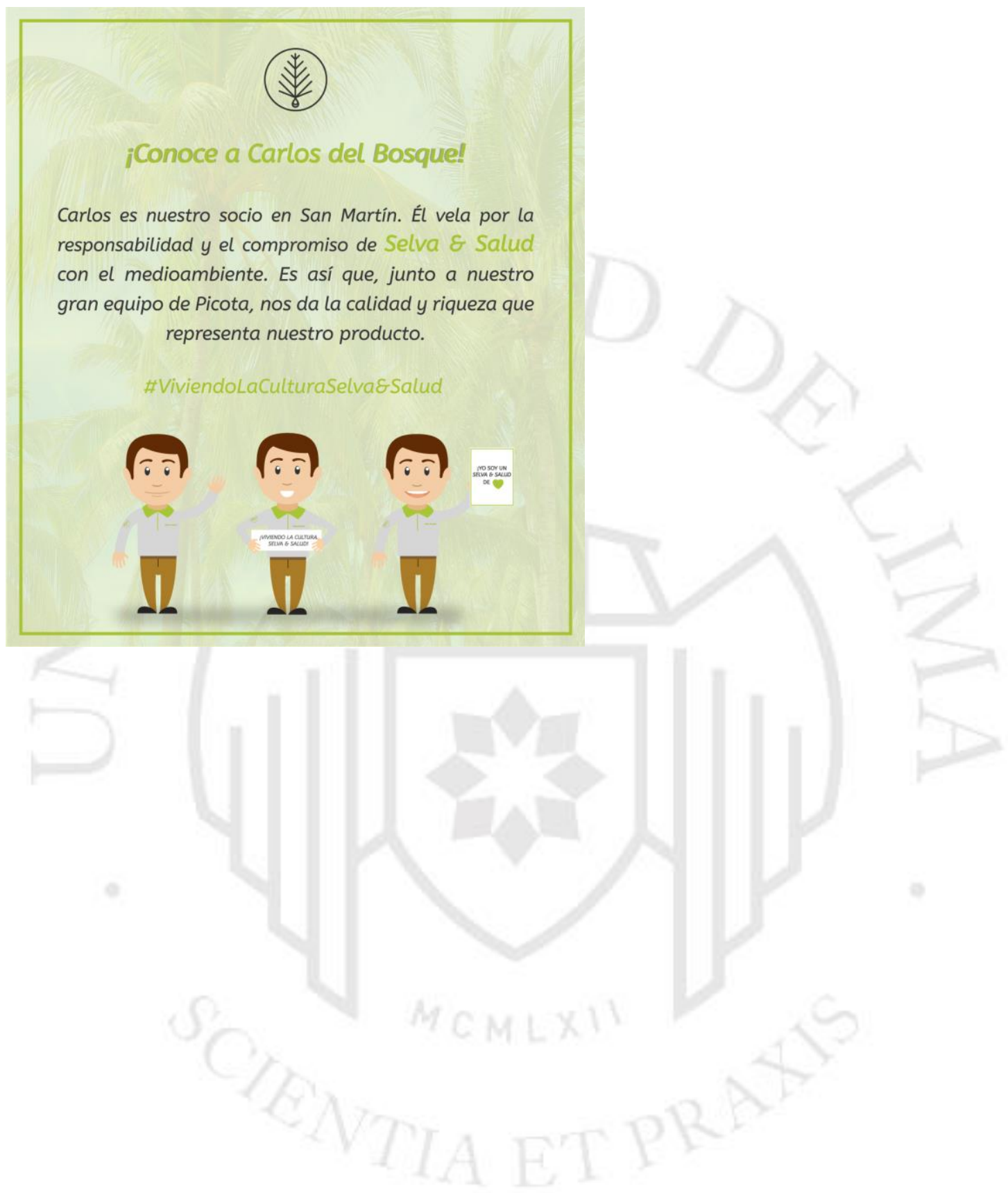


Polos corporativos para los colaboradores de Selva \& Salud

https://drive.google.com/drive/folders/1B81ZAuLcMfQFBY_qdPPRJryjRDHkWEeY? usp=sharing

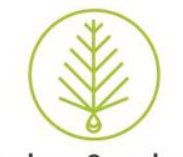

selva \& salud

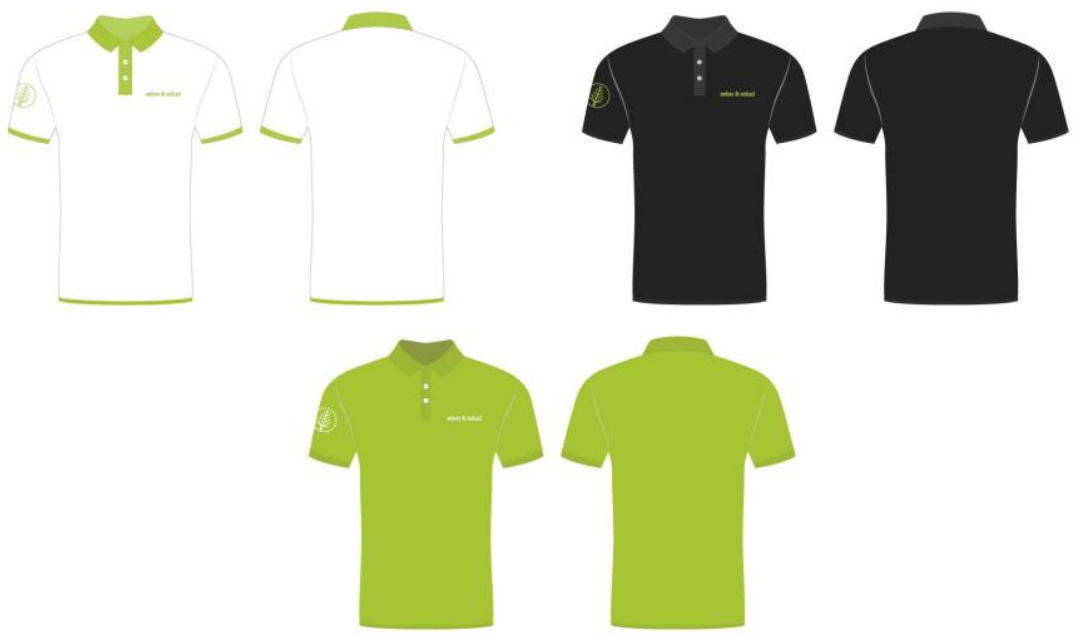




\section{IX: PROYECCIÓN DEL PLAN ESTRATÉGICO DE COMUNICACIÓN AL 2023}

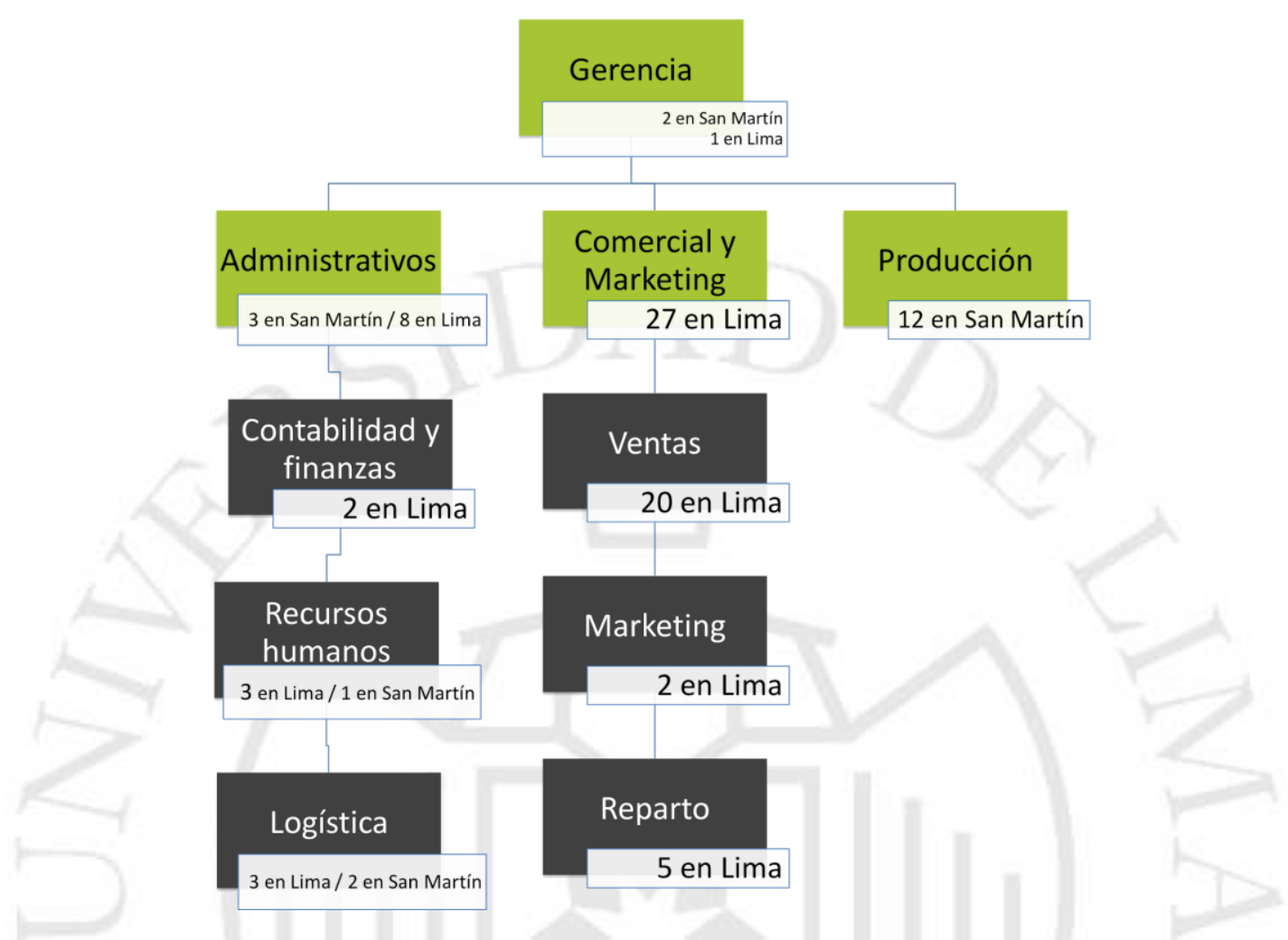

Con el primer año del plan se podrá dar los cimientos de Selva \& Salud, reconociendo cómo se aplica la cultura instaurada y qué emociones, experiencias y nuevos conocimientos genera en el colaborador de Lima y San Martín, en la comunidad, clientes, proveedores y demás grupos de interés involucrados. Ante ello, se espera aumentar el reconocimiento de marca por canales físicos y digitales, apostar por una propuesta de valor que inicie a solidificarse y comunicarse, a una mayor cartera de clientes fidelizados y un colaborador identificado con la cultura de su empresa y que la aplica con entusiasmo. Además, un mayor conocimiento de las familias en Coco Bosque, sus necesidades y visión a largo plazo, así como el crecimiento en puntos de venta y mayores oportunidades de negocio.

En el año 1, la concentración de personal se encuentra en el área de Comercia y Ventas, seguido por Producción y Administración. Para los siguientes cuatro años se busca poder incrementar el número personal de manera paulatina, haciendo énfasis en las áreas del producción y ventas, agregando nuevas sub áreas orientadas a la gestión del personal y su bienestar y el crecimiento nacional e internacional.

A continuación, se presenta las áreas que se buscan fortalecer, restructurar o instaurar en Selva \& Salud, así como los planes a los siguientes cuatro años. 


\section{Producción:}

Será el área al que más colaboradores se le asignen, para asegurar el incremento de la producción y estar en la capacidad de triplicarla en 5 años.

A partir del año 2 se incorporará un Ingeniero de planta con conocimientos en Industrias Alimentarias. Y para el año 3 un segundo Ingeniero. Ambos no solo velarán por los niveles de producción de los productos de Selva \& Salud, sino también harán visitas y darán soporte a Coco Bosque y nuevos proyectos con los que se trabaje. Además, para el año 2 se busca aperturar un área de Aseguramiento de Calidad que, en coordinación con el equipo mencionado anteriormente, aseguren los niveles de calidad y certificaciones que aporten valor al producto y negocio.

Como parte de la estrategia de crecimiento de la empresa se explorará y desarrollará además el Mercado Externo; en donde se presentan altos niveles de calidad. Es por ello la importancia de asegurar nuestros productos, así como los brindados por Coco Bosque.

\section{Administración}

En esta área se encontrarán Contabilidad y Finanzas, tomando en consideración que, si se requiere más recursos por el incremento de actividades; se evaluará que funciones o actividades puedan ser tercerizadas

Además, se busca contar con un encargado de Sistemas que sea el responsable de brindar soporte técnico en hardware y software a todos los usuarios de la empresa, responsable de la ejecución de los backups y actualizaciones del sistema, siendo un apoyo también para generar proyectos de innovación en la empresa que estén alineados a los objetivos corporativos.

\section{Ventas:}

En esta área se plantea el desarrollo de vendedores viajeros y el desarrollo del Comercio Exterior. Se ha fijado el año 3 como parámetro para la incorporación de colaboradores. En ese año se espera tener los niveles de inventarios suficientes para poder contar con un nivel sostenido de oferta al mercado y con altos niveles de calidad.

En el área de Ventas será necesario hacer una reestructuración de la Fuerza de Ventas, para enfocarla a Clientes actuales y potenciales; creando zonas de ventas para así mantener un mejor orden en la atención y servicio.

Para mejorar su identificación hacia el mercado se conocerán a los vendedores de Selva \& Salud como Ejecutivos de Ventas. 


\section{Marketing:}

Alineados a los niveles de producción y calidad que se obtengan, el área de Marketing dará el soporte para la búsqueda de nuevos mercados asistiendo a Ferias del rubro en los años de proyección.

En ellas podremos colocar Stands para la presentación de nuestros productos. En estas ferias también podremos captar clientes potenciales a los cuales nuestros vendedores puedan ir a presentarles los beneficios del producto actual y los que se desarrollen.

En lo que respecta al Mercado de Exportaciones, el área de Marketing hará las coordinaciones pertinentes para tener presencia en las principales Ferias del Exterior. Con ello se asegurará que el área de Ventas pueda utilizar los contactos para poder ofrecer los productos de Selva \& Salud.

Por otro lado, se busca expandir el crecimiento de la venta de los productos mediante el e-commerse, llevando a mayores públicos. Para ello, se realizará una campaña de difusión y aprendizaje con el área de Comunicación.

\section{Logística:}

Considerando los niveles de crecimiento es necesario fortalecer el área Logística en las instalaciones de San Martín, para asegurar que los productos sean correctamente almacenados, que se tengan los inventarios al día y se asegure la correcta rotación de los inventarios. De esta manera, se asegura que los productos siempre estarán en perfecto estado.

Los colaboradores del área serán los que se encarguen de hacer los despachos hacia Lima y, de ser necesario, prepararán los que vayan destinados a la Exportación.

Los colaboradores de Lima, darán soporte al equipo de Ventas en provincias (Ejecutivos de Ventas) para asegurar la atención oportuna de los pedidos. En caso exista algún reclamo de los clientes de provincias, se harán cargo de solucionarlos, manteniendo informado al área de Ventas.

Dado el crecimiento de la organización se evaluará la compra de hardware, nuevos camiones para mercadería, así como la compra o alquiler de una oficina en Lima. En el caso de San Martín se evaluará la compra de nuevas instalaciones o la restructuración de espacios tales como Sala de Reuniones, comedor, sala de descanso o recibimiento de clientes, instalaciones seguras y atractivas para la muestra del proceso productivo del aceite de coco y otros productos, entre otros. La tienda ubicada en Surquillo también se restructurará para darle un estilo natural, que muestre los productos de manera llamativa

\section{Recursos Humanos:}

Considerando el plan de incremento de los colaboradores, se fortalecerá el área de Recursos Humanos basada en funciones tales como Recursos Humanos en sí (planillas), Comunicación y Bienestar Social. Una de las principales funciones será la de desarrollar 
el plan de incorporación de los colaboradores, plan de evaluación del desempeño, así como dar soporte para contar con las funciones y responsabilidades de cada cargo de la empresa.

El área de Comunicación trabajará de la mano principalmente con los encargados del área de producción, buscando que los contactos sean fluidos no solo con los colaboradores de la empresa, sino también con los Coco Bosque y otras áreas de producción o socios que puedan incorporarse como parte del "proceso productivo" de la empresa, asegurando así los niveles de inventario y desarrollo de nuevos productos.

Es muy importante que los colaboradores o terceros pertenecientes a este proceso productivo conozcan las políticas y filosofía de Selva \& Salud para buscar un alto grado de identificación.

En cuanto al área de Bienestar Social, la cual se busca implementar en San Martín en el año 2, se enfocará principalmente de atender los requerimientos o consultas de los colaboradores que viven en San Martín y de sus familias; para asegurar que se sientan cómodos y a gusto de pertenecer a la empresa. Este colaborador tendrá el apoyo del equipo de Recursos Humanos en Lima.

Para Recursos humanos, el desarrollo de la gestión del personal desde su ingreso hasta desvinculación es muy importante. El colaborador debe reconocer que Selva \& Salud lo apoya en su crecimiento personal y profesional, así como al desarrollo de sus familias. Como forma de apoyo a los colaboradores de la empresa, se planteará un sistema de Becas de Estudios en el año 3 para los hijos que tengan un promedio de 15 a más; la Beca consistirá en una sustentación económica estimada en S/350. También se desarrollará un plan de vacaciones útiles a implementar a finales del año 1.

Como parte del desarrollo de los hijos de los colaboradores, al culminar sus estudios podrán ingresar a laborar en Selva \& Salud, previa a una evaluación para desarrollar sus prácticas pre profesionales.

Por otro lado, con el objetivo de mantener y fortalecer el Clima Laboral de la empresa y el compromiso de los colaboradores, se realizará un proyecto con las esposas e hijas llamado "Madres Emprendedoras" en el año 4. En este programa se busca que, dentro de las necesidades que presentan y sus intereses de aprendizaje, se creen talleres orientados al cuidado del medioambiente, la sostenibilidad, la innovación y creatividad y el reconocimiento de sus fortalezas para aplicarlas en proyectos que les generen rentabilidad. Se busca que este programa sea financiado por la organización.

Finalmente, alineados al bienestar y cuidado, se desarrollarán, en San Martín desde el año 4 en adelante, campañas de vacunación, exámenes médicos, psicológicos, talleres de habilidades blandas, talleres de matemática, lenguaje y gestión empresarial para adultos, entre otros que apuesten a su crecimiento. En la sede de Lima, se generarán alianzas para contar con diversos beneficios de restaurantes, entretenimiento, cultura, viajes, así como capacitaciones más especializadas y viajes de innovación para aplicar proyectos nuevos en la organización que generen crecimiento. 


\section{RECOMENDACIONES}

La implementación de este Plan de comunicación requiere el apoyo y participación de otras áreas involucradas. Antes de iniciar, es importante que se cumplan las siguientes condiciones:

- El espacio en cada sede debe estar acondicionado adecuadamente con el equipo y mobiliario necesario para los colaboradores.

- Cada colaborador debe contar con un equipo electrónico para sus labores, sea computadora, laptop o celular (a excepción del equipo de producción en San Martín, quienes compatirán las 2 computadoras adquiridas).

- Se debe garantizar una conexión potente y constante de internet, ya sea inalámbrico o por fibra óptica, de modo que las videollamadas se puedan desarrollar sin problemas de conexión.

- La seguridad en las oficinas es de vital importancia, vista no solo desde el cuidado y resguardo de las oficinas, sino también desde el punto de vista de la seguridad y salud en el trabajo. Los colaboradores deben trabajar en un espacio cómodo, ergonómico y bien iluminado. En el caso de los trabajadores de campo, deberán contar con el equipo de protección personal correspondiente a sus labores.

- Se debe contar con una línea telefónica corporativa que servirá para las distintas actividades propuestas como el grupo en Whatsapp, así como la línea de atención al cliente. 


\section{REFERENCIAS}

Alberto Muñoz. (2013). El coco, ese gran desconocido. 2019, de Organización de las Naciones Unidas para la Alimentación y la Agricultura, Sitio web: https://www.elmundo.es/vida$\underline{\text { sana/2015/10/07/561387ceca4741cc7d8b4582.html }}$

Aljure, A. S. (2015) El plan estratégico de comunicación: método y recomendaciones prácticas para su elaboración.

Angie Higuchi. (2015). Características de los consumidores de productos orgánicos y expansión de su oferta en Lima. 2019, de Universidad del Pacífico Sitio web:

http://www.scielo.org.pe/scielo.php?script=sci_arttext\&pid=S0252-18652015000200002

Antonieta Hamann Pastorino. (2013). El márketing verde. El compromiso de todos. 2019, de ESAN Sitio web:

https://www.esan.edu.pe/publicaciones/2013/06/11/tiempo de opinion antonieta hamann.pdf

APEGA. (2016). Productos orgánicos y bioferias ganan terreno en Perú. 2019, de APEGA Sociedad Peruana de Gastronomía Sitio web: http://www.apega.pe/noticias/prensa-ydifusion/productos-organicos-y-bioferias-ganan-terreno-en-peru.html

Ashes to life. (2019). El aceite de coco en cosmética. Fuente de vida para la piel. 2019, del aceite de coco en cosmética. Fuente de vida para la piel Sitio web:

https://www.ashestolife.es/el-aceite-de-coco-en-cosmetica-fuente-de-vida-para-la-piel/

Castro, Julio (11 de agosto del 2016). La importancia de la tecnología en las empresas en crecimiento. Recuperado de https://blog.corponet.com.mx/importancia-de-la-tecnologia-en-lasempresas-en-crecimiento

Costa, J. (2004) Dircom on-line: el master de dirección de comunicación a distancia.

Gestión (4 de agosto del 2018). Amazonía peruana pierde 23,000 hectáreas de bosques en el primer semestre. Recuperado de https://gestion.pe/economia/amazonia-peruana-pierde-23-000hectareas-bosques-primer-semestre-240567

Greenpeace. (2018). Agricultura ecológica. 2019, de Greenpeace Sitio web: http://archivoes.greenpeace.org/espana/es/Trabajamos-en/Transgenicos/Soluciones-y-demandas/Agriculturaecologica/

IFOAM. (2018). El sector orgánico mundial en auge. 2019, de Organización Internacional Agropecuaria Sitio web: https://www.oia.com.ar/novedades/detalle/437/el-sector-organicomundial-en-auge

Instituto Nacional de Estadística e Informática INEI (Abril del 2019). Informe técnico de la Producción Nacional. Recuperado de https://www.inei.gob.pe/media/MenuRecursivo/boletines/04-informe-tecnico-n-04-produccionnacional-feb2019.pdf

José Garcia. (2017). Tendencias en cosméticos: Lo natural y sostenible vende. 2019, de AINIA Sitio web: https://www.ainia.es/tecnoalimentalia/consumidor/tendencias-cosmetica-naturalsostenible/ 
JULEN IZAGIRRE OLAIZOLA. (2016). E GUSTA, PERO NO LO VOY A COMPRAR: LA BRECHA ENTRE PREDISPOSICIÓN Y CONSUMO ECOLÓGICO. 2019, de Universidad del País Vasc Sitio web:

https://addi.ehu.es/bitstream/handle/10810/17955/TESIS IZAGUIRRE OLAIZOLA JULEN.p df? sequence $=1 \&$ is Allowed $=y$

Julen Izagirre-Olaizola, Ana Fernández-Sainz, María Vicente-Molina. (2013). Antecedentes y barreras a la compra de productos ecológicos. 2019, de UNIVERSIA Sitio web: https://search.proquest.com/openview/7084eeff446271f72a599566be60a8a8/1?pqorigsite $=$ gscholar

La República. (2018). Datum presenta estudio sobre "vida saludable”. 2019, de La República Sitio web: https://larepublica.pe/marketing/1200803-datum-presenta-estudio-sobre-vidasaludable

Marcos Anampa, Jhoel Cercado, José Rivas. (2017). Productos Orgánicos Peruanos. Alternativa de desarrollo y negocio. 2019, de Universidad Ricardo Palma Sitio web:

https://es.slideshare.net/joseguillermorch/productos-organicos-peruanos

Marga Fernández. (2018). Tendencias 2018 en el desarrollo de productos cosméticos. 2019, de AINIA Sitio web:

https://www.ainia.es/tecnoalimentalia/consumidor/4-tendencias-productos-cosmeticos/

Ministerio Nacional de Agricultura y Riego (MINAGRI) (2018). Plan Nacional de Cultivos. Recuperado de https://www.agromoquegua.gob.pe/doc/PLAN_NACIONAL_DE_CULTIVOS_2018-2019.pdf

Ministerio Nacional de Agricultura y Riego (MINAGRI) (2017). Exportaciones e importaciones 2017. Recuperado de http://siea.minagri.gob.pe/siea/sites/default/files/datoscomercio-exterior-ene17.xls

Ministerio Nacional de Agricultura y Riego (MINAGRI) (2012). Principales aspectos de la Cadena Agroproductiva. Recuperado de

http://agroaldia.minagri.gob.pe/biblioteca/download/pdf/agroeconomia/corregidopalma.pdf

Mirtha Trigoso. (2017). El 34\% de hogares limeños decidió cambiar sus hábitos alimenticios en el último año. 2019, de Gestión Sitio web: https://gestion.pe/economia/empresas/34-hogareslimenos-decidio-cambiar-habitos-alimenticios-ano-221291

Observatory of Economics Complexity (2017). El aceite de coco. Recuperado de https://atlas.media.mit.edu/es/profile/hs92/1513/

Peñarada, C. (2 de enero del 2018). Economía peruana podría crecer 3,9\% en el 2018.

Recuperado de

https://www.camaralima.org.pe/repositorioaps/0/0/par/edicion808/edicion_808.pdf

Pilar Macarena Eguillor Recabarren. (2018). Agricultura orgánica: oportunidades y desafíos. 2019, de Oficina de Estudios y Políticas Agrarias Sitio web: https://www.odepa.gob.cl/wpcontent/uploads/2018/07/agriculturaOrganica2018-1.pdf

Programa Nacional de Conservación de Bosques (http://www.bosques.gob.pe/)

SERFOR (https://www.serfor.gob.pe/) 
Silvia Wu, Fernando Alvarado. (2015). Agricultores y consumidores comparten intereses. 2019, de LEISA: revista de agroecología Sitio web: http://www.leisa-al.org/web/index.php/volumen31-numero-2

Veritrade (2019). Aceite de coco (de copra) y sus fracciones: aceite en bruto. Recuperado de https://www.veritradecorp.com/es/peru/importaciones-y-exportaciones/aceite-de-coco-decopra-y-sus-fracciones-aceite-en-bruto/151311

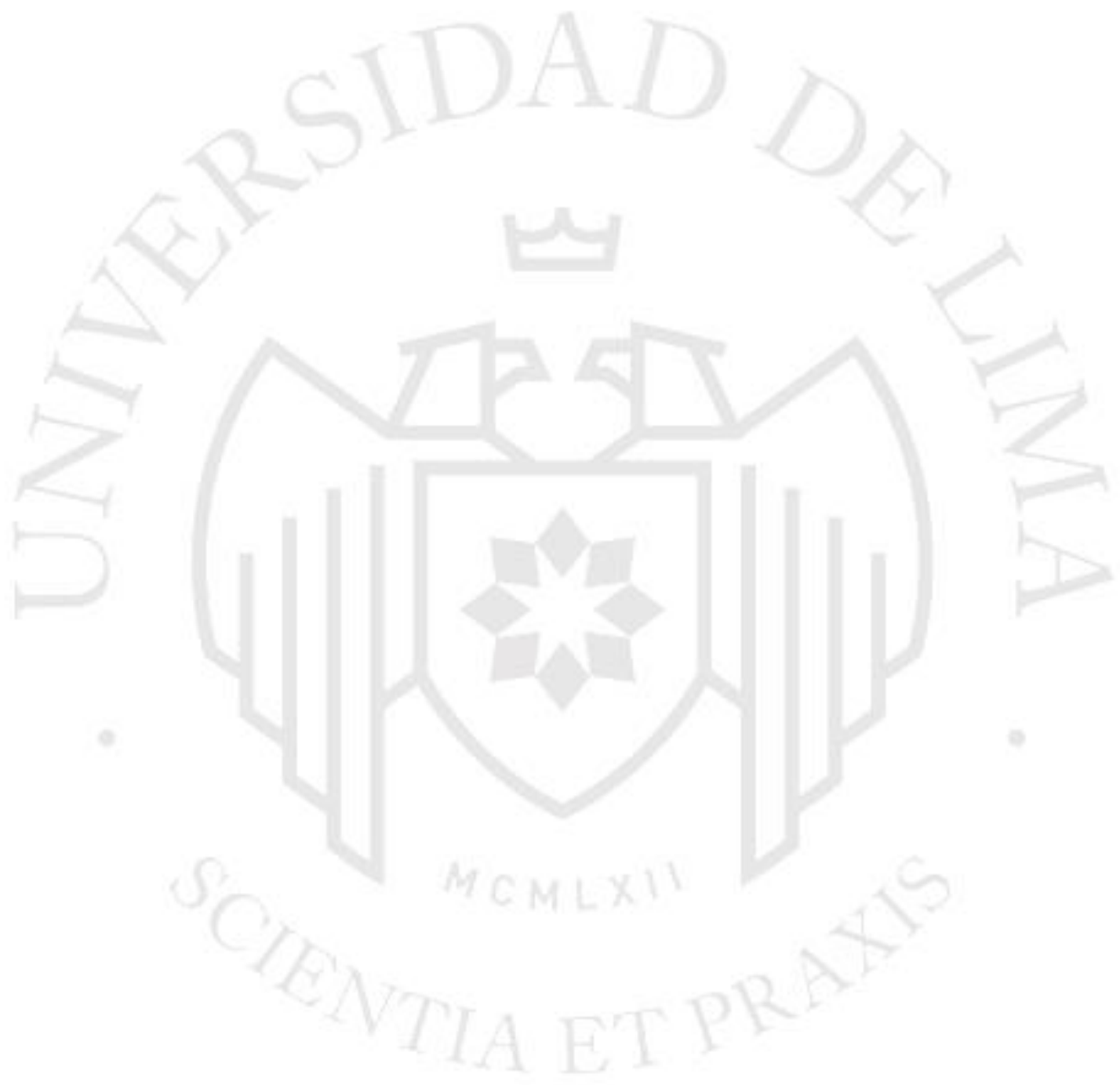

